\title{
VARIATION OF MITOCHONDRIAL CONTROL REGION SEQUENCES OF STELLER SEA LIONS, EUMETOPIAS JUBATUS: THE THREE-STOCK HYPOTHESIS
}

\author{
A Thesis \\ by \\ ALYSON RENEE BAKER \\ Submitted to the Office of Graduate Studies of \\ Texas A\&M University \\ in partial fulfillment of the requirements for the degree of \\ MASTER OF SCIENCE
}

December 2003

Major Subject: Genetics 


\title{
VARIATION OF MITOCHONDRIAL CONTROL REGION SEQUENCES OF STELLER SEA LIONS, EUMETOPIAS JUBATUS: THE THREE-STOCK HYPOTHESIS
}

\author{
A Thesis
}

By

\author{
ALYSON RENEE BAKER \\ Submitted to Texas A\&M University \\ in partial fulfillment of the requirements \\ for the degree of \\ MASTER OF SCIENCE
}

Approved as to style and content by:

John W. Bickham

(Chair of Committee)

Rodney L. Honeycutt

(Member)

Geoffrey M. Kapler

(Chair of Genetics Faculty)
Thomas R. Loughlin (Member)

J. Spencer Johnston (Member)

Robert D. Brown

(Head of Department)

December 2003

Major Subject: Genetics 


\author{
ABSTRACT \\ Variation of Mitochondrial Control Region Sequences of Steller Sea Lions, Eumetopias \\ jubatus: The Three-Stock Hypothesis. (December 2003) \\ Alyson Renee Baker, B.S., Grove City College \\ Chair of Advisory Committee: Dr. John W. Bickham
}

Sequence variation of a 238 bp segment of the mitochondrial control region was analyzed for 1,568 Steller sea lions $(2.8 \%$ of the estimated species population) sampled from 50 rookeries representing nearly every locality at which Steller sea lions are known to breed in significant numbers. Haplotype diversity $(\mathrm{H}=0.9164 \pm 0.0035)$ was high and nucleotide diversity $(\pi=0.00967 \pm 0.00586)$ was moderate. No evidence was observed for significant genetic bottleneck effects. Rookeries were grouped into regions and stocks to examine structure at different spatial scales. F- and $\Phi$-statistics were computed for all pairwise comparisons of rookeries, regions and stocks. Significant $(\mathrm{P} \leq 0.05)$ divergence of eastern stock (southeastern Alaska to California) animals from western stock animals was supported in analyses at all spatial scales. Likewise, rookeries and regions from Asia were found to be significantly different from all other western stock rookeries. This was most clearly demonstrated using $\Phi$-statistics at the regional level. The Commander Islands clearly associate with Alaskan western stock rookeries, not with the Asian rookeries. Within each of the three stocks there is significant isolation by distance among rookeries. This relationship does not hold for inter-stock comparisons indicating that there are important barriers to gene flow among 
stocks. Mitochondrial DNA analysis supports the recognition of three stocks for appropriate conservation of the species. The currently recognized eastern stock is unaffected, but the western stock is now partitioned west of the Commander Islands yielding a western stock which ranges from Prince William Sound west to the Commander Islands, and an Asian stock including rookeries from the Kamchatka Peninsula, Kuril Islands, and Sea of Okhtosk. 


\section{DEDICATION}

This thesis is dedicated to my mother and father without whose continuous support I might not have considered tackling a higher degree, to my brother who inspires me to excel, and to my grandparents who always encouraged their children and grandchildren to further their education. 


\section{ACKNOWLEDGEMENTS}

I would like to thank the many people involved in collecting the tissues used in this study, especially Drs. Thomas R. Loughlin, Thomas Gelatt, Vladimir Burkanov and Mr. Donald G. Calkins. Without your efforts my research would not have been possible. Most of the mitochondrial haplotype data used for population analyses were generated from previous studies at Texas A\&M and LGL Ecological Research Associates, Inc. I am thankful to those students, technicians and scientists whose research efforts made this invaluable data set available for analysis.

I would especially like to thank my advisor, Dr. John Bickham, and committee members, Dr. Rodney Honeycutt, Dr. J. Spencer Johnston and Dr. Tom Loughlin, for their critiques (and for their patience) during the thesis-writing process.

Dr. John Patton provided continual guidance and support in the lab. I would like to thank Cole Matson who prepared and ran tests of population subdivision for this study. Cole, Ryan Huebinger, and Robert Trujillo guided me through the dreaded ordeal of data analysis and for this I am very grateful. 
ABSTRACT _ iii

DEDICATION

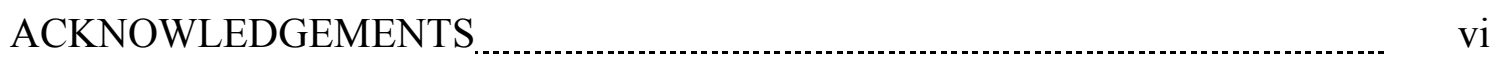

TABLE OF CONTENTS

LIST OF FIGURES $\ldots$ ix

LIST OF TABLES

INTRODUCTION

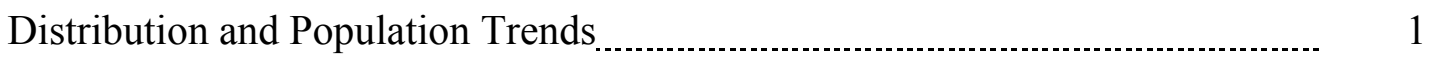

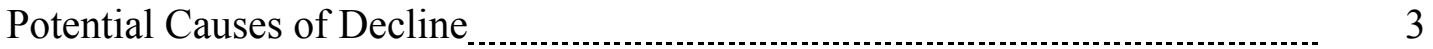

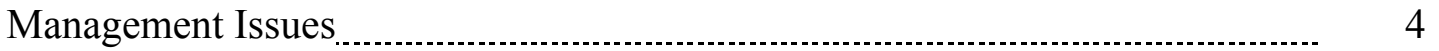

METHODS

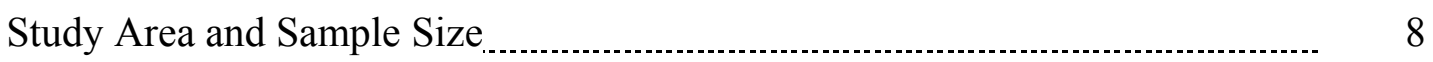

Molecular Methods

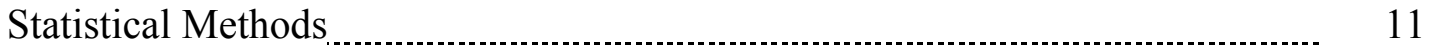

RESULTS

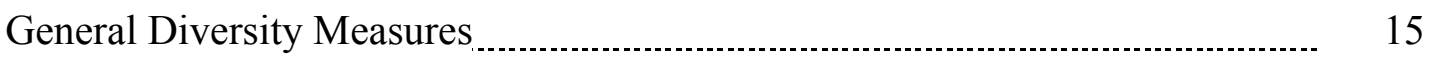

Measures of Genetic Distance _................................................................ 17

DISCUSSION $\ldots \ldots \ldots \ldots$

Mitochondrial Control Region Diversity _............................................ 28

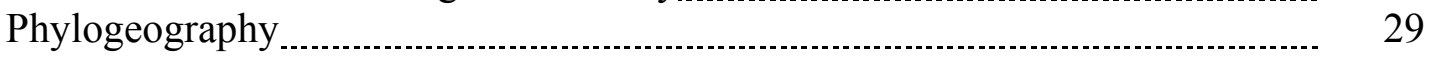

Inter- and Intra-Stock Patterns of Migration and Stock Structure _...................... 31

CONCLUSIONS

LITERATURE CITED 
viii

Page

APPENDIX I

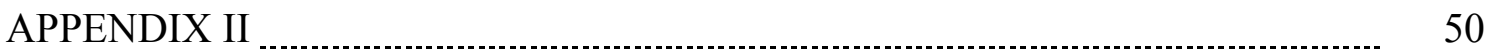

VITA 


\section{LIST OF FIGURES}

FIGURE

Page

1 Map Indicating the Location of Steller Sea Lion Rookeries

Sampled in this Study

2 Distribution of Haplotype Frequencies Observed in 1,568

Steller Sea Lions Range-wide

3 Distribution of Four Common D-loop Haplotypes, A, DD, $\mathrm{H}$, and LLL at the Rookery Level.

4 Neighbor Joining Tree based on Slatkin's Linearized $F_{\text {st }}$

(Conventional) Values at the Rookery Level

5 Neighbor Joining Tree based on Slatkin's Linearized Fst Analogues $\left(\Phi_{\mathrm{st}}\right)$ at the Rookery Level

6 Neighbor Joining Trees based on Slatkin's Linearized

F-statistics at the Region Level

7 Neighbor Joining Trees based on Slatkin's Linearized

F-statistics at the Stock Level 


\section{LIST OF TABLES}

TABLE

Page

1 Number of Steller Sea Lions Sampled from throughout the Range of the Species

2 Haplotype $(\mathrm{H})$ and Nucleotide $(\pi)$ Diversities for Rookeries and Regions

3 Control Region Haplotype Designations, the Number of Haplotypes Found, and the Proportion of the Total Sample for 1,568 Steller Sea Lions Sampled from Rookeries throughout the Range of the Species

4 Slatkin's Linearized F-Statistics for all Pairwise Region Comparisons Based on mtDNA Data 


\section{INTRODUCTION}

\section{$\underline{\text { Distribution and }} \underline{\text { Population Trends }}$}

Steller's sea lion, Eumetopias jubatus, was described by George Wilhelm Steller in 1742; they are the largest member of the family Otariidae (Gentry and Withrow, 1986). The Steller sea lion is endemic to the north Pacific Ocean and Bering Sea. Rookeries are distributed along an arc following the edge of the north Pacific Rim with three located in the Bering Sea. Distribution of the rookeries ranges from the west coast of the continental United States (California and Oregon), north along the Canadian and Alaskan coasts, west across the Gulf of Alaska, Aleutian Islands and Commander Islands, along the east coast of the Kamchatka Peninsula, within the Sea of Okhotsk, and southwest throughout the Kuril Islands (Fig. 1).

While Steller sea lions were believed to number between 240,000 and 300,000 in the late 1950's and early 1960's (Kenyon and Rice, 1961) and between 245,000 and 290,000 during the 1980's (Loughlin et al., 1984), their populations experienced a significant decline in the years that followed with only 116,000 present in 1989 (Loughlin et al., 1992). Likewise, the U.S. population was estimated at 192,000 in the 1960's but numbered only 52,000 in 1994 (Anonymous, 1995). Such extreme losses attracted worldwide attention and led to the Steller sea lion being listed as threatened under the U.S. Endangered Species Act in 1990.

This thesis follows the style and format of the Journal of Mammalogy. 


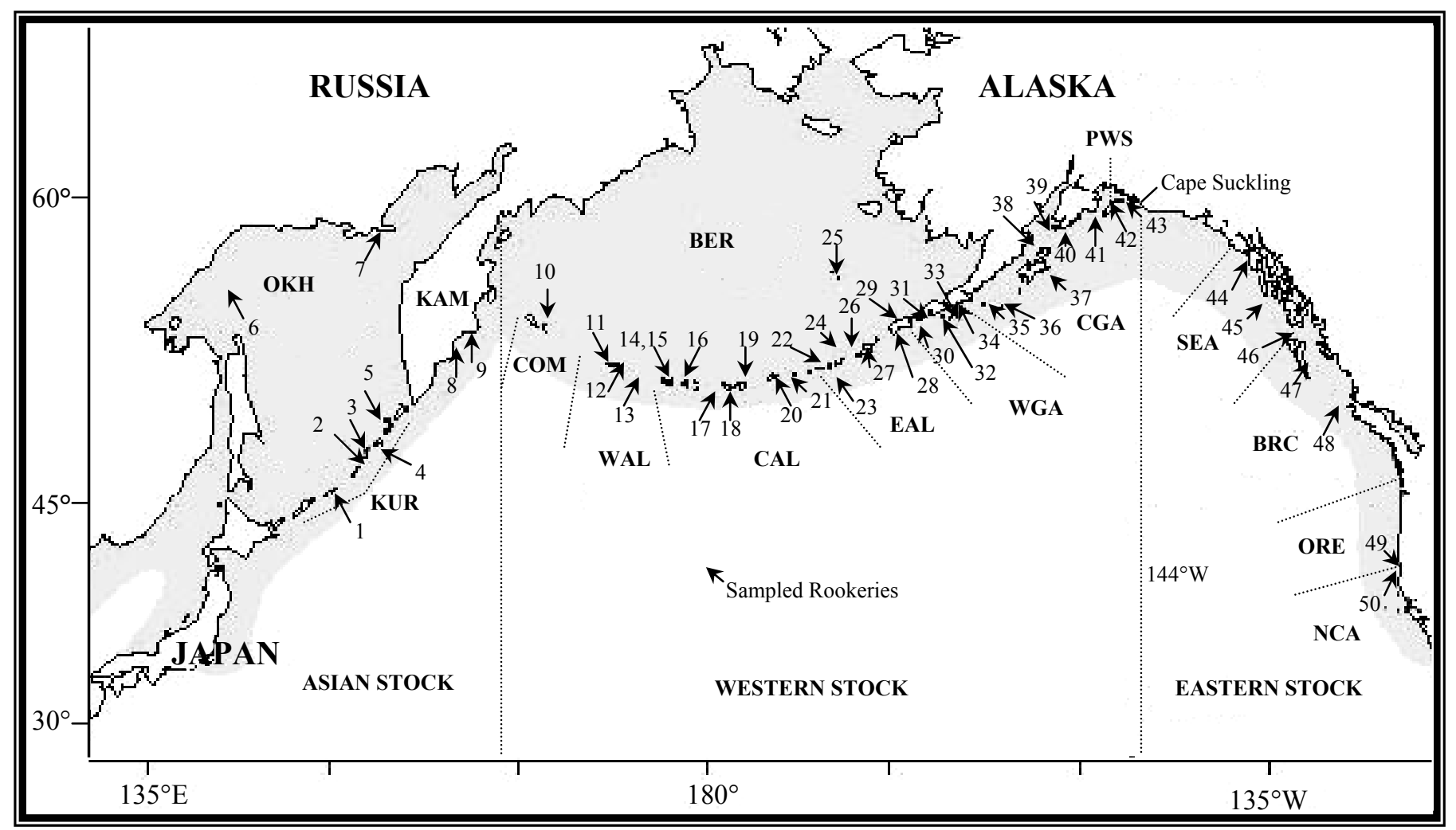

Rookery locations are indicated by numbered arrows: $1=$ Chernyye Brat'ya, $2=$ Srednego, $3=$ Raykoke, $4=$ Lovushki, $5=$ Antsiferova, $6=$ Iony, $7=$ Yamsky, $8=$ Zheleznaya Bay, $9=$ Kozlova Cape, $10=$ Medney, $11=$ Attu, $12=$ Agattu, $13=$ Buldir, 14, $15=$ Kiska, Cape St. Stephen and Lief Cove, $16=$ Amchitka, $17=$ Ulak, $18=$ Gramp Rock, $19=$ Kasatoshi, $20=$ Seguam, 21 = Yunaska, $22=$ Adugak, $23=$ Ogchul, $24=$ Bogoslof, $25=$ Walrus, $26=$ Akutan, $27=$ Akun, $28=$ Ugamak, $29=$ Amak, $30=$ Clubbing Rocks, $31=$ Pinnacle Rock, $32=$ Chernabura, $33=$ Whaleback, $34=$ Atkins, $35=$ Chowiet, $36=$ Chirikof, $37=$ Marmot, $38=$ Latax Rocks, $39=$ Sugarloaf, $40=$ Chiswell, $41=$ Fish, $42=$ Seal Rocks, $43=$ Cape St. Elias, 44 $=$ White Sisters, $45=$ Hazy, $46=$ Forrester, $47=$ North Danger Rocks, $48=$ Triangle, $49=$ Rogue Reef, and $50=$ St. George Reef. Region designations are: BER $=$ Bering Straight, CAL $=$ Central Aleutian Islands, $\mathrm{CGA}=$ Central Gulf of Alaska, EAL $=$ Eastern Aleutian Islands, WAL $=$ Western Aleutian Islands, WGA $=$ Western Gulf of Alaska, COM $=$ Commander Islands, $\mathrm{KUR}=$ Kuril Islands, $\mathrm{OKH}=$ Sea of Okhotsk, $\mathrm{KAM}=$ Kamchatka Peninsula, $\mathrm{BRC}=$ British Columbia, NCA $=$ Northern California, ORE $=$ Oregon, $\mathrm{PWS}=$ Prince William Sound, SEA = Southeastern Alaska.

Fig. 1. Map indicating the location of Steller sea lion rookeries sampled in this study. Regions and stocks are defined according to the results of this study. 


\section{$\underline{\text { Potential Causes of Decline }}$}

The ultimate reason for the population decline is unknown, but a number of potential factors have been tested over the years. These factors include, but are not limited to, relocation, short-term environmental stochasticity, human exploitation, pollution and disease, changed vital rates, competition with commercial fisheries and major oceanic regime shifts (Loughlin, 1998).

Upon completion of a range-wide survey in 1989, Loughlin et al. (1992) noted population declines occurring throughout the species range leading them to conclude that animals were not simply relocating from one region to another. Also, population modeling suggested that the Steller sea lion decline was due to factors more complex than natural fluctuations of the north Pacific environment (short-term environmental stochasticity; Pascual and Adkison, 1994). Furthermore, while Steller sea lions were hunted extensively for their oil, testes, whiskers and hides during the 1860's (Helling, 1984; Mate, 1976) they are no longer harvested for commercial purposes. In addition, levels of subsistence use have decreased as Steller sea lion populations have declined (Haynes and Mishler, 1994). Therefore, relocation, short-term environmental fluctuations, and human exploitation cannot explain the current decline.

Researchers have studied the impacts of pollution on pinniped populations including effects of the Exxon Valdez Oil Spill (Calkins et al., 1994; Loughlin et al., 1996), accumulation of trace metals such as copper, mercury (Sydeman and Jarman, 1998), and vanadium (Saeki et al., 1999), and biomagnification of toxic compounds such as tributyltin (TBT; Kim et al., 1996a, 1996b), organochlorines (Lee et al., 1996), and 
polycyclic aromatic hydrocarbons (PAHs; Albers and Loughlin, 2003). These studies do provide evidence linking pollution to the decline of Steller sea lions. The prevalence of disease has received less attention simply because disease symptoms (such as lesions, abortion, premature births, etc.) have not been observed in great numbers. Still, the impact of viruses and other pathogens is considered minimal (Loughlin, 1998).

York (1994) suggested that a 10-20\% decrease in juvenile mortality could account for the degree of decline noted for Steller sea lions. While this discovery is critical, decreased juvenile mortality still represents only a proximate cause of population decline.

Competition with commercial fisheries for limited resources has long been suspected as a main contributor to marine mammal declines. Overfishing of walleye pollock (Theragra chalcogramma), for example, is thought to be potentially damaging to Steller sea lion populations because pollock are currently the top prey species of many marine predators (Lowry et al., 1988).

Some researchers suspect a major oceanic regime shift might have caused a change in the prey base of the Steller sea lion and indirectly contributed to the species decline (Alverson, 1998; Trites et al., 1999). However, it seems likely that the cause of the decline is multi-factorial and we may never completely understand it.

\section{$\underline{\text { Management Issues }}$}

Following listing of the Steller sea lion as threatened in 1990, a number of studies attempted to clarify not only the cause(s) of decline but also to describe Steller 
sea lion physiology, behavior, and population dynamics. Several population genetic studies contributed to our understanding of Steller sea lion genetic diversity and natural history (Bickham et al., 1996, 1998a, 1998b). In contrast to previous molecular studies that indicated little to no genetic diversity in Steller sea lion populations, or pinnipeds in general (Lidicker et al., 1981), Bickham et al. (1996) reported high variability for mitochondrial control region sequences. The mitochondrial genome is maternally inherited in mammals, undergoes no recombination, and is estimated to evolve at a rate 5-10 times faster than nuclear genes; these characteristics, combined with female philopatry, make mitochondrial DNA (mtDNA) a useful molecular marker to define population subdivision (Honeycutt, 2000).

Significant genetic divergence of control region sequences was observed between animals sampled from rookeries in the Commander and Aleutian Islands and the Gulf of Alaska and those from southeastern Alaska through Oregon (regions west and east, respectively, of Cape Suckling, Alaska; longitude 144 W). Bickham et al. (1996) suggested that the overall population be divided into two genetically distinct management units, the western and eastern stocks. Further genetic research, as well as accumulated information regarding Steller sea lion distribution, phenotypic variation, and population response, supported the decision to recognize two stocks (Loughlin, 1997; Bickham et al., 1998a, 1998b). The western stock, which is continuing to decline, was listed as endangered in 1997. The current western stock population of Alaska comprises approximately 26,000 non-pup animals (Sease and Gudmundson, 2002) and stock loses are estimated at 5\% per year (Sease et al., 2001). At this rate of decline less 
than a thousand animals will comprise the population west of Cape Suckling, Alaska, to the westernmost tip of the Aleutian Islands in the year 2020 (Loughlin and York, 2000). In contrast, eastern stock numbers have increased it remains listed as threatened.

Management units have been assigned based on genetic and other criteria for a number of marine mammals having distributions similar to that of the Steller sea lion. For instance, harbor seals (Phoca vitulina) are distributed throughout the north Pacific, and the United States currently recognizes three management units within U.S. waters. Interestingly, mtDNA analysis revealed that current management stocks in Alaska were inappropriate, and researchers suggested that additional genetic data be analyzed to ensure proper conservation of the species (Westlake and O'Corry-Crowe, 2002). Sea otters (Enhydra lutris) are also distributed throughout the north Pacific. Morphological characters were used to designate three subspecies range-wide (Cronin et al., 1996). E. $l$. lutris occurs from Japan eastward throughout the Kuril and Commander Island chains, E. l. kenyoni is found from the westernmost tip of the Aleutian Islands east throughout the Bering Sea, Gulf of Alaska, Canada and Oregon, and E. l. nereis is distributed from California southward along the Mexican west coast. Again, mtDNA analysis resolved population substructure different from that obtained when analyzing morphological characters (Cronin et al., 1996). Analysis of the control region revealed four distinct groups, and sea otters from the Commander Islands, although morphologically like $E . l$. lutris, were most genetically similar to E. l. kenyoni. These studies highlight the utility of mtDNA analysis in designation of management units for marine mammal conservation. 
Still further tests are needed to define population structure within the far western limits of the Steller sea lion distribution. Previous research has indicated that animals sampled from Russian rookeries (rookeries in the Sea of Okhotsk, the Kuril Islands, Kamchatka Peninsula, and the Commander Islands) were genetically distinct from other western stock sea lions (Bickham et al., 1998b; Trujillo et al., in press). However, sample sizes were generally inadequate to arrive at a confident decision regarding western stock substructure.

This study includes mtDNA sequence data for a total of 1,568 Steller sea lions taken from 50 rookeries from throughout the range of the species. Nearly every locality at which this species is known to breed was sampled, and the sample size represents $2.8 \%$ of the 53,400 extant non-pup population estimated from range-wide counts made during the years 2000 to 2002 . This paper specifically focuses on a population-genetic assessment of mtDNA variability and stock structure in the western range of the Steller sea lion. 


\section{METHODS}

\section{$\underline{\text { Study }}$ Area and Sample Size}

Tissue samples obtained from rear flipper punches and preserved in saturated $\mathrm{NaCl}$ with $20 \%$ DMSO were initially stored at room temperature (Amos and Hoelzel, 1991) and later archived at $-80^{\circ} \mathrm{C}$. All samples are from pups taken from their natal rookeries. The total sample size for this study was $n=1,568$ and the number of animals sampled per rookery, region and stock are given in Table 1.

\section{$\underline{\text { Molecular Methods }}$}

Total genomic DNA was extracted using established organic methods (Maniatis et al., 1982). Primers designed by LGL Inc. (Bryan, TX) were utilized for amplification of a $450 \mathrm{bp}$ region of the mitochondrial control region (D-loop). These primers are LGL 283 (5'-TACACTGGTCTTCTAAACC-3') and LGL 1115 (5'-

ATGACCCTGAAGAA(A/G)GAACCAG-3'). LGL 283 is complementary to a region within the tRNA ${ }^{\text {Thr }}$ gene while LGL 1115 binds to a region within the D-loop. The partial D-loop sequence was amplified using the polymerase chain reaction (PCR), and PCR conditions were as follows: $0.05-0.1 \mu \mathrm{g}$ genomic DNA, $5 \mu 110 \mathrm{X}$ Taq salts $(0.1 \mathrm{M}$ Tris $\left.\cdot \mathrm{HCl}, \mathrm{pH} 8.4-8.7,0.025 \mathrm{M} \mathrm{MgCl}_{2}, 0.5 \mathrm{M} \mathrm{KCl}\right), 5 \mu \mathrm{dNTP} \operatorname{mix}(2 \mathrm{mM}$ dATP, dCTP,

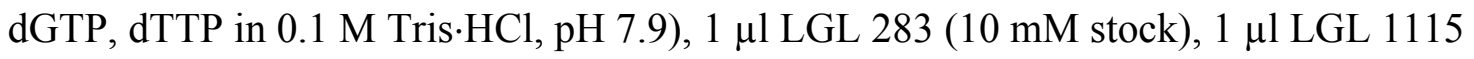
(10 mM stock), $0.5 \mu 1$ Taq DNA polymerase and the appropriate amount of distilled water (final reaction volume $=50 \mu \mathrm{l}$ ). $\mathrm{PCR}$ amplifications were performed using either the Robocycler ${ }^{\circledR}$ (Stratagene, La Jolla, CA) or GeneAmp ${ }^{\circledR}$ PCR System 2700 (Applied 
Table 1. Number of Steller sea lions sampled from throughout the range of the species.

\begin{tabular}{|c|c|c|c|}
\hline STOCK & REGION & ROOKERY & SAMPLE SIZE \\
\hline \multirow[t]{35}{*}{ WESTERN STOCK } & $\operatorname{BER}(\mathrm{n}=22)$ & Walrus Is. & 22 \\
\hline & \multirow{9}{*}{ CAL $(n=203)$} & Amchitka Island & 10 \\
\hline & & Gramp Rocks & 10 \\
\hline & & Kasatoshi & 10 \\
\hline & & Kiska Island, Cape St. Stephen & 47 \\
\hline & & \begin{tabular}{|l|} 
Kiska Island, Lief Cove \\
\end{tabular} & 46 \\
\hline & & \begin{tabular}{|l} 
Ogchul Island \\
\end{tabular} & 10 \\
\hline & & \begin{tabular}{|l} 
Seguam Island \\
\end{tabular} & 31 \\
\hline & & \begin{tabular}{|l} 
Ulak Island \\
\end{tabular} & 9 \\
\hline & & Yunaska Island & 30 \\
\hline & $\operatorname{COM}(n=106)$ & Medney Island & 106 \\
\hline & \multirow[t]{7}{*}{ CGA (n = 122) } & Cape St. Elias & 3 \\
\hline & & \begin{tabular}{|l|} 
Chirikof Island \\
\end{tabular} & 31 \\
\hline & & \begin{tabular}{|l|} 
Chiswell Island \\
\end{tabular} & 6 \\
\hline & & \begin{tabular}{|l|} 
Coweit Island \\
\end{tabular} & 10 \\
\hline & & Latax Rocks & 1 \\
\hline & & Marmot Island & 50 \\
\hline & & Sugarloaf Island & 21 \\
\hline & \multirow[t]{6}{*}{ EAL $(n=227)$} & Adugak Island & 10 \\
\hline & & \begin{tabular}{|l|} 
Akun Island \\
\end{tabular} & 13 \\
\hline & & Akutan Island & 85 \\
\hline & & \begin{tabular}{|l|} 
Amak Island \\
\end{tabular} & 9 \\
\hline & & Bogoslof Island & 11 \\
\hline & & Ugumak Island & 99 \\
\hline & \multirow[t]{2}{*}{ PWS (n=124) } & Fish Island & 47 \\
\hline & & \begin{tabular}{|l|} 
Seal Rocks \\
\end{tabular} & 77 \\
\hline & \multirow[t]{3}{*}{ WAL $(\mathbf{n}=\mathbf{5 5})$} & Agatu Island & 25 \\
\hline & & \begin{tabular}{|l|} 
Attu Island \\
\end{tabular} & 10 \\
\hline & & Buldir & 20 \\
\hline & \multirow[t]{5}{*}{ WGA (n = 99) } & Atkins Island & 36 \\
\hline & & \begin{tabular}{|l|} 
Chernabura Island \\
\end{tabular} & 5 \\
\hline & & \begin{tabular}{|l|} 
Clubbing Rocks \\
\end{tabular} & 26 \\
\hline & & Pinnacle Island & 30 \\
\hline & & Whaleback Island & 2 \\
\hline & Western Stock Total & & 958 \\
\hline \multirow[t]{10}{*}{ ASIAN STOCK } & \multirow[t]{5}{*}{ KUR $(n=207)$} & Antsiferova Island & 45 \\
\hline & & Chernyye Brat'ya & 31 \\
\hline & & Lovushki Island & 39 \\
\hline & & Raikoke Island & 51 \\
\hline & & Srednego Island & 41 \\
\hline & \multirow[t]{2}{*}{ OKH $(n=148)$} & Iony Island & 100 \\
\hline & & Yamsky Island & 48 \\
\hline & \multirow[t]{2}{*}{ KAM $(n=71)$} & Kozlova Cape & 59 \\
\hline & & Zheleznaya Bay & 12 \\
\hline & Asian Stock Total & & 426 \\
\hline \multirow[t]{8}{*}{ EASTERN STOCK } & \multirow[t]{2}{*}{ BRC $(n=23)$} & North Danger Rocks & 10 \\
\hline & & \begin{tabular}{|l} 
Triangle Island \\
\end{tabular} & 13 \\
\hline & NCA $(n=10)$ & St. George Reef & 10 \\
\hline & $\overline{\text { ORE }(n=83)}$ & \begin{tabular}{|l} 
Rogue Reef \\
\end{tabular} & 83 \\
\hline & \multirow{3}{*}{ SEA $(n=68)$} & Forester Island & 11 \\
\hline & & \begin{tabular}{|l} 
Hazy Islands \\
\end{tabular} & 37 \\
\hline & & White Sisters Is. & 20 \\
\hline & Eastern Stock Total & & 184 \\
\hline ENTIRE RANGE & Total Sample Size & & 1568 \\
\hline
\end{tabular}

Note- Region designations are: $\mathrm{BER}=$ Bering Straight, $\mathrm{CAL}=$ Central Aleutian Islands, $\mathrm{CGA}=$ Central Gulf of Alaska, EAL $=$ Eastern Aleutian Islands, WAL $=$ Western Aleutian Islands, WGA $=$ Western Gulf of Alaska, $\mathrm{COM}=$ Commander Islands, KUR = Kuril Islands, $\mathrm{OKH}=$ Sea of Okhotsk, $\mathrm{KAM}=$ Kamchatka Peninsula, $\mathrm{BRC}=$ British Columbia, NCA $=$ Northern California, ORE $=$ Oregon, PWS = Prince William Sound, SEA = Southeastern Alaska. The total number of animals sampled per region is indicated in parentheses. Regions and stocks are defined according to the results of this study. 
Biosystems, Foster City, CA). When amplifying with the Robocycler ${ }^{\circledR}$, the following PCR parameters were utilized: initial cycle (denature at $95{ }^{\circ} \mathrm{C}$ for $3 \mathrm{~min}$, anneal at $50{ }^{\circ} \mathrm{C}$ for $1 \min 25 \mathrm{~s}$, extend at $70{ }^{\circ} \mathrm{C}$ for $2 \min 50 \mathrm{~s}$ ) followed by 32 cycles (denature at $95{ }^{\circ} \mathrm{C}$ for $1 \min 10 \mathrm{~s}$, anneal at $50^{\circ} \mathrm{C}$ for $1 \min 25 \mathrm{~s}$, extend at $70{ }^{\circ} \mathrm{C}$ for $2 \min 50 \mathrm{~s}$ ), and hold at $4{ }^{\circ} \mathrm{C}$. When amplifying with the GeneAmp ${ }^{\circledR} 2700$, the PCR parameters were as follows: 1 cycle $\left(94{ }^{\circ} \mathrm{C}\right.$ for $5 \mathrm{~min}$ ), 32 cycles (denature at $94{ }^{\circ} \mathrm{C}$ for $45 \mathrm{~s}$, anneal at $50{ }^{\circ} \mathrm{C}$ for $40 \mathrm{~s}$, extend at $72{ }^{\circ} \mathrm{C}$ for $2 \mathrm{~min} 30 \mathrm{~s}$ ), ending with 2 cycles (extend at $72{ }^{\circ} \mathrm{C}$ for 7 min, hold at $\left.4{ }^{\circ} \mathrm{C}\right)$.

Amplified products were visualized using agarose gel electrophoresis ( $1 \%$ agarose). The QIAquick ${ }^{\circledR}$ PCR purification kit (Qiagen, Valencia, CA) was used to purify PCR products in preparation for sequencing. Sequencing reactions utilized fluorescent dye-terminator technology and were run on either the Robocycler ${ }^{\circledR}$ or GeneAmp ${ }^{\circledR}$ 2700. PCR products were sequenced in only one direction with LGL 1115. The sequencing reaction conditions were as follows: 0.04-0.05 $\mu \mathrm{g}$ purified PCR product, $2 \mu 1$ BigDye ${ }^{\circledR}$ terminator (Applied Biosystems, Foster City, CA), $1.8 \mu 15 \mathrm{X}$ sequencing buffer (400 mM Tris·HCl pH 9.0, $10 \mathrm{mM} \mathrm{MgCl}$ ), 2 ㅅ LGL 1115 (10 mM stock) and the appropriate volume of distilled water (final reaction volume $=10 \mu 1$ ). The following PCR parameters were applied for all sequencing reactions run on the Robocycler $^{\circledR}$ : initial cycle (denature at $96^{\circ} \mathrm{C}$ for $3 \mathrm{~min}$, anneal at $50{ }^{\circ} \mathrm{C}$ for $1 \mathrm{~min}$, extend at $60{ }^{\circ} \mathrm{C}$ for $4 \mathrm{~min}$ ), 25 cycles (denature at $96{ }^{\circ} \mathrm{C}$ for $1 \mathrm{~min}$, anneal at $50{ }^{\circ} \mathrm{C}$ for $1 \mathrm{~min}$, extend at 60 ${ }^{\circ} \mathrm{C}$ for $\left.4 \mathrm{~min}\right)$. When using the GeneAmp ${ }^{\circledR} 2700$, the following parameters were applied: 
1 cycle $\left(96^{\circ} \mathrm{C}\right.$ for $5 \mathrm{~min}$ ), 25 cycles (denature at $96^{\circ} \mathrm{C}$ for $30 \mathrm{~s}$, anneal at $50{ }^{\circ} \mathrm{C}$ for $15 \mathrm{~s}$, extend at $60{ }^{\circ} \mathrm{C}$ for $4 \mathrm{~min}$ ), ending with 2 cycles (extend at $60{ }^{\circ} \mathrm{C}$ for $4 \mathrm{~min}$, hold at 4 $\left.{ }^{\circ} \mathrm{C}\right)$.

Sequencing reactions were purified using sephadex columns. The purified products were then pelleted and later prepared for loading on an ABI Prism ${ }^{\circledR} 377$ automated DNA sequencer (Applied Biosystems, Foster City, CA). ABI Prism ${ }^{\circledR}$ software was used to collect the raw sequence data which was later analyzed using Sequencher ${ }^{\mathrm{TM}}$ 4.1.2 (Gene Codes, Ann Arbor, MI). Haplotypes were assigned to individuals based on nucleotide differences within the $238 \mathrm{bp}$ region of the mitochondrial control region.

\section{Statistical Methods}

The proportion of nucleotide sites that differ $\left(\mathrm{p}_{\mathrm{n}}\right)$ within the 238 bp sequence was calculated by dividing the number of variable sites by the total number of nucleotides (Hedrick, 2000). Haplotype diversity ( $H$; Nei and Tajima, 1981) and nucleotide diversity $(\pi ;$ Nei, 1987) were determined for rookery and region population levels using ARLEQUIN (Schneider et al., 2000).

Exact tests for significant population differentiation for all pairwise comparisons using rookeries with $N \geq 10$, regions and stocks were conducted in ARLEQUIN. This test is analogous to Fisher's exact test on a $2 \times 2$ contingency table but extended to an $r \times$ $k$ contingency table (Raymond and Rousset, 1995). Two separate measures of the degree of genetic divergence occurring between subdivisions of a population, 
conventional F-(Wright, 1951) and Ф-statistics (Excoffier, 1992), were estimated using ARLEQUIN. Conventional $F_{\text {st }}$ parameter estimates infer population structure using only haplotype frequencies, while $\Phi_{\text {st }}$ (F-statistic analogues) parameter estimates incorporate both haplotype frequencies and the number of mutations observed between haplotypes. The F- and $\Phi$-statistics are therefore referred to as frequency- and genetic-based parameters, respectively (Westlake and O'Corry-Crowe, 2002). The Tamura and Nei (1993) measure of evolutionary distance between nucleotide sequences was used to calculate the approximate number of mutations differing between haplotypes prior to running $\Phi_{\text {st }}$ analyses. Probabilities for all measures of genetic distance were estimated using 10,000 randomizations of the original data set; this represents a 10-fold increase over the minimum number of permutations required to obtain an accurate probability estimate (Schneider et al., 2000). In addition, a transformation (Slatkin, 1995) was applied when calculating both $\mathrm{F}_{\text {st }}$ and $\Phi_{\text {st }}$ estimates to linearize population divergence time and distance (Schneider et al., 2000). The results are matrices of genetic distances consisting of positive values only. Neighbor-joining (NJ) trees were generated using the matrices of genetic distances calculated for all pairwise comparisons at the rookery, region and stock levels (for both the $\mathrm{F}_{\mathrm{st}}$ and $\Phi_{\text {st }}$ methods) using PAUP* 4.0 (Swofford, 1998). All trees were constructed using midpoint rooting.

Regressions of genetic distance $\left(\mathrm{F}_{\mathrm{st}}\right.$ and $\left.\Phi_{\mathrm{st}}\right)$ on geographic distance and correlations between genetic and geographic distances among rookeries were computed using the R Package, version 4.0 (Casgrain and Legendre, 2001). Matrices of geographic distances were constructed using surface distances for all possible pairwise 
comparisons among the 43 rookeries represented by a sample size of $N \geq 10$. The $R$ Package was then used to test the null hypothesis of independence between genetic and geographic distances by estimating departures from randomness using a variation of the Z-statistic (Mantel, 1967). Significance of the test statistic was then estimated using 99,999 permutations of the data.

Lastly, a maximum-likelihood approach was applied at the stock level to estimate the number of effective migrants per generation, $\mathrm{N}_{\mathrm{f}} m$, where $\mathrm{N}_{\mathrm{f}}$ represents the number of effectively breeding females and $m$ is the migration rate (Hartl and Clark, 1997). Original estimates of $\mathrm{N}_{\mathrm{f}} m$ were obtained by running two replicates using MIGRATE (Beerli, 1997-2002) default settings which calculate initial parameter estimates from $\mathrm{F}_{\text {st }}$ values. The average of the two estimates was then calculated for each parameter, and these values replaced $\mathrm{F}_{\mathrm{st}}$ estimates in following runs. The program was then run until equivalent estimates were obtained between replicates. The length of runs (number of short and long chains and length of chains) was generally increased to ensure a more accurate estimation of population parameters. 
Table 2. Haplotype $(\mathrm{H})$ and nucleotide $(\pi)$ diversities for rookeries and regions. Standard deviations for all estimates are also provided.

\begin{tabular}{|c|c|c|}
\hline Rookery & Haplotype Diversity (H) & Nucleotide Diversity $(\pi)$ \\
\hline Adugak Is. & $0.867 \pm 0.0714$ & $0.00871 \pm 0.00601$ \\
\hline Agatu Is. & $0.873 \pm 0.039$ & $0.00848 \pm 0.0055$ \\
\hline Akun Is. & $0.859 \pm 0.0633$ & $0.00921 \pm 0.00611$ \\
\hline Akutan Is. & $0.879 \pm 0.0187$ & $0.00928 \pm 0.00574$ \\
\hline Amchitka Is. & $0.844 \pm 0.103$ & $0.00662 \pm 0.00485$ \\
\hline Antsiferova Is. & $0.929 \pm 0.0241$ & $0.00924 \pm 0.00578$ \\
\hline Atkins Is. & $0.89 \pm 0.0245$ & $0.00881 \pm 0.0056$ \\
\hline Attu Is. & $0.889 \pm 0.0754$ & $0.00817 \pm 0.00571$ \\
\hline Bogoslof Is. & $0.873 \pm 0.0891$ & $0.0101 \pm 0.0067$ \\
\hline \begin{tabular}{|l} 
Buldir Is. \\
\end{tabular} & $0.916 \pm 0.0413$ & $0.00887 \pm 0.00576$ \\
\hline Chernyye Brat'ya & $0.873 \pm 0.0358$ & $0.0079 \pm 0.00516$ \\
\hline Chirikof Is. & $0.837 \pm 0.0432$ & $0.00879 \pm 0.00561$ \\
\hline Chowiet Is. & $0.644 \pm 0.152$ & $0.00605 \pm 0.00454$ \\
\hline Clubbing Rocks & $0.831 \pm 0.0485$ & $0.00629 \pm 0.00436$ \\
\hline Fish Is. & $0.878 \pm 0.0232$ & $0.00924 \pm 0.00577$ \\
\hline Forester Is. & $0.982 \pm 0.0463$ & $0.0123 \pm 0.00787$ \\
\hline Gramp Rocks & $0.911 \pm 0.0773$ & $0.00737 \pm 0.00527$ \\
\hline Hazy Is. & $0.89 \pm 0.033$ & $0.0104 \pm 0.00639$ \\
\hline Iony Is. & $0.782 \pm 0.0385$ & $0.0066 \pm 0.0044$ \\
\hline Kasatoshi Is. & $0.689 \pm 0.104$ & $0.00585 \pm 0.00442$ \\
\hline Kiska, Cape St. Stephen & $0.881 \pm 0.0225$ & $0.00877 \pm 0.00554$ \\
\hline Kiska, Lief Cove & $0.838 \pm 0.0344$ & $0.0084 \pm 0.00536$ \\
\hline Kozlova Is. & $0.863 \pm 0.033$ & $0.00786 \pm 0.00506$ \\
\hline Lovushki Is. & $0.888 \pm 0.0294$ & $0.00794 \pm 0.00514$ \\
\hline Marmot Is. & $0.8045 \pm 0.0454$ & $0.00733 \pm 0.00481$ \\
\hline Medney Is. & $0.9 \pm 0.0141$ & $0.00989 \pm 0.00602$ \\
\hline North Danger Rocks & $0.8 \pm 0.1$ & $0.00875 \pm 0.00603$ \\
\hline Ogchul & $0.933 \pm 0.062$ & $0.012 \pm 0.00782$ \\
\hline Pinnacle Rocks & $0.86 \pm 0.0472$ & $0.00861 \pm 0.00553$ \\
\hline Raykoke Is. & $0.882 \pm 0.0265$ & $0.00697 \pm 0.00463$ \\
\hline Rogue Reef & $0.909 \pm 0.0167$ & $0.0111 \pm 0.00666$ \\
\hline Seal Rocks & $0.876 \pm 0.0253$ & $0.00905 \pm 0.00563$ \\
\hline Seguam Is. & $0.89 \pm 0.033$ & $0.00942 \pm 0.00593$ \\
\hline Sredgego Is. & $0.867 \pm 0.0332$ & $0.00683 \pm 0.00458$ \\
\hline St. George Reef & $0.867 \pm 0.107$ & $0.00902 \pm 0.00617$ \\
\hline \begin{tabular}{|l} 
Sugarloaf Is. \\
\end{tabular} & $\begin{array}{ll}0.9 & 0.039 \\
\end{array}$ & $0.0101 \pm 0.00643$ \\
\hline Triangle Is. & $0.961 \pm 0.0412$ & $0.0114 \pm 0.00727$ \\
\hline Ugamak Is. & $0.869 \pm 0.0235$ & $0.00904 \pm 0.00561$ \\
\hline Walrus Is. & $0.866 \pm 0.0519$ & $0.00918 \pm 0.00589$ \\
\hline White Sisters Is. & $0.963 \pm 0.0255$ & $0.0161 \pm 0.00945$ \\
\hline \begin{tabular}{|l} 
Yamsky Is. \\
\end{tabular} & $0.871 \pm 0.0303$ & $0.0071 \pm 0.0047$ \\
\hline \begin{tabular}{|l} 
Yunaska Is. \\
\end{tabular} & $0.752 \pm 0.0711$ & $0.00794 \pm 0.00519$ \\
\hline Zheleznaya Bay & $0.848 \pm 0.0744$ & $0.00605 \pm 0.00445$ \\
\hline Region & Haplotype Diversity (H) & Nucleotide Diversity $(\pi)$ \\
\hline Sea of Okhotsk & $0.815 \pm 0.0271$ & $0.00675 \pm 0.00445$ \\
\hline Kuril Islands & $0.894 \pm 0.0127$ & $0.00782 \pm 0.00498$ \\
\hline Kamchatka Peninsula & $0.867 \pm 0.0308$ & $0.00762 \pm 0.00493$ \\
\hline Commander Islands & $0.9 \pm 0.0141$ & $0.00989 \pm 0.00602$ \\
\hline Western Aleutian Islands & $0.895 \pm 0.0204$ & $0.00867 \pm 0.00547$ \\
\hline Central Aleutian Islands & $0.858 \pm 0.0145$ & $0.00882 \pm 0.00547$ \\
\hline Eastern Aleutian Islands & $0.871 \pm 0.0141$ & $0.00918 \pm 0.00564$ \\
\hline Western Gulf of Alaska & $0.856 \pm 0.0194$ & $0.00808 \pm 0.00513$ \\
\hline Central Gulf of Alaska & $0.818 \pm 0.0276$ & $0.00812 \pm 0.00514$ \\
\hline Bering Sea & $0.866 \pm 0.0519$ & $0.00918 \pm 0.00589$ \\
\hline Prince William Sound & $0.879 \pm 0.0171$ & $0.00923 \pm 0.00569$ \\
\hline Southeastern Alaska & $0.931 \pm 0.0143$ & $0.0122 \pm 0.00719$ \\
\hline British Columbia & $0.901 \pm 0.0414$ & $0.0101 \pm 0.00637$ \\
\hline Oregon & $0.909 \pm 0.0167$ & $0.0111 \pm 0.00666$ \\
\hline Northern California & $0.867 \pm 0.107$ & $0.00902 \pm 0.00617$ \\
\hline
\end{tabular}




\section{RESULTS}

\section{General Diversity Measures}

A 238 base pair region of the mitochondrial control region (D-loop) was analyzed for sequence variation. The number of polymorphic sites equaled 46 , all of which were substitutions (40 transitions, 6 transversions). The proportion of polymorphic sites $\left(\mathrm{p}_{\mathrm{n}}\right)$ equaled $46 / 238$, or 0.193 . Haplotype diversity was high $(\mathrm{H}=$ $0.9164 \pm 0.0035)$ as expected due to rapid evolution and divergence of the D-loop. Nucleotide diversity was low $(\pi=0.00967 \pm 0.00586)$ because nearly all haplotypes differed by a single substitution event. Haplotype and nucleotide diversities for rookeries and regions are provided in Table 2.

A total of 121 haplotypes was observed (all individuals sampled, sample information, and assigned D-loop haplotypes for the additional 359 sea lions sampled from Asia are listed in Appendix I) including 46 new haplotypes (AAAA-NNNN, PPPPZZZZ, AAAAA, QQQQQ-ZZZZZ, AAAAAA-JJJJJJ; J. W. Bickham, pers. comm.). S and $\mathrm{BB}$ were by far the most common haplotypes detected, representing $18.2 \%$ and $15.9 \%$ of the sample, respectively (Table 3). Frequencies of all other haplotypes were less than $10 \%$. Thus, an L-shaped distribution was obtained when haplotype number was plotted against haplotype frequency class (Fig. 2). Many haplotypes were restricted to certain regions. For instance, LLL was found only in Asia, DD was restricted to the Aleutian Islands and Gulf of Alaska, $\mathrm{H}$ was only found in eastern stock rookeries, and A was distributed range-wide (Fig. 3). 
Table 3. Control region haplotype designations, the number of haplotypes found, and the proportion of the total sample for 1,568 Steller sea lions sampled from rookeries throughout the range of the species.

\begin{tabular}{|c|c|c|c|c|c|}
\hline Haplotype & Number & Proportion (\%) & Haplotype & Number & Proportion (\%) \\
\hline $\mathrm{A}$ & 121 & 7.72 & MMMM & 1 & 0.06 \\
\hline $\mathrm{AA}$ & 2 & 0.13 & $\mathrm{~N}$ & 15 & 0.96 \\
\hline AAA & 38 & 2.42 & $\mathrm{NN}$ & 1 & 0.06 \\
\hline AAAA & 14 & 0.89 & NNN & 1 & 0.06 \\
\hline AAAAA & 1 & 0.06 & NNNN & 1 & 0.06 \\
\hline AAAAAA & 2 & 0.13 & $\mathrm{O}$ & 1 & 0.06 \\
\hline $\mathrm{B}$ & 1 & 0.06 & $\mathrm{OO}$ & 1 & 0.06 \\
\hline $\mathrm{BB}$ & 249 & 15.88 & $\mathrm{OOO}$ & 2 & 0.13 \\
\hline $\mathrm{BBB}$ & 1 & 0.06 & $\mathrm{P}$ & 4 & 0.26 \\
\hline BBBB & 1 & 0.06 & $\mathrm{PP}$ & 1 & 0.06 \\
\hline BBBBBB & 1 & 0.06 & PPP & 1 & 0.06 \\
\hline $\mathrm{C}$ & 2 & 0.13 & PPPP & 1 & 0.06 \\
\hline $\mathrm{CC}$ & 115 & 7.33 & $\mathrm{Q}$ & 9 & 0.57 \\
\hline $\mathrm{CCC}$ & 1 & 0.06 & QQ & 1 & 0.06 \\
\hline CCCC & 1 & 0.06 & QQQ & 1 & 0.06 \\
\hline $\mathrm{CCCCCC}$ & 1 & 0.06 & QQQQ & 1 & 0.06 \\
\hline $\mathrm{D}$ & 1 & 0.06 & QQQQQ & 1 & 0.06 \\
\hline DD & 40 & 2.55 & $\mathrm{R}$ & 9 & 0.57 \\
\hline DDD & 6 & 0.38 & RR & 2 & 0.13 \\
\hline DDDD & 1 & 0.06 & RRR & 1 & 0.06 \\
\hline DDDDDD & 1 & 0.06 & RRRR & 2 & 0.13 \\
\hline $\mathrm{E}$ & 59 & 3.76 & RRRRR & 1 & 0.06 \\
\hline $\mathrm{EE}$ & 9 & 0.57 & $\mathrm{~S}$ & 286 & 18.24 \\
\hline EEE & 4 & 0.26 & SS & 2 & 0.13 \\
\hline EEEE & 4 & 0.26 & SSS & 1 & 0.06 \\
\hline EEEEEE & 1 & 0.06 & SSSS & 1 & 0.06 \\
\hline $\mathrm{F}$ & 4 & 0.26 & SSSSS & 4 & 0.26 \\
\hline FF & 50 & 3.19 & $\mathrm{~T}$ & 7 & 0.45 \\
\hline FFF & 5 & 0.32 & TT & 1 & 0.06 \\
\hline FFFF & 17 & 1.08 & TTT & 2 & 0.13 \\
\hline FFFFFF & 1 & 0.06 & TTTT & 1 & 0.06 \\
\hline $\mathrm{G}$ & 24 & 1.53 & TTTTT & 1 & 0.06 \\
\hline GG & 1 & 0.06 & $\mathrm{U}$ & 13 & 0.83 \\
\hline GGG & 1 & 0.06 & UU & 1 & 0.06 \\
\hline GGGG & 3 & 0.19 & UUU & 13 & 0.83 \\
\hline GGGGGG & 1 & 0.06 & UUUU & 3 & 0.19 \\
\hline $\mathrm{H}$ & 32 & 2.04 & UUUUU & 1 & 0.06 \\
\hline $\mathrm{HH}$ & 26 & 1.66 & $\mathrm{~V}$ & 1 & 0.06 \\
\hline $\mathrm{HHH}$ & 1 & 0.06 & VV & 1 & 0.06 \\
\hline HHHH & 1 & 0.06 & VVV & 2 & 0.13 \\
\hline НHНHНH & 2 & 0.13 & VVVV & 4 & 0.26 \\
\hline $\mathrm{I}$ & 3 & 0.19 & VVVVV & 1 & 0.06 \\
\hline II & 1 & 0.06 & $\mathrm{~W}$ & 28 & 1.79 \\
\hline III & 7 & 0.45 & WW & 4 & 0.26 \\
\hline IIII & 2 & 0.13 & WWW & 3 & 0.19 \\
\hline IIIIII & 1 & 0.06 & WWWW & 4 & 0.26 \\
\hline $\mathrm{J}$ & 2 & 0.13 & WWWWW & 2 & 0.13 \\
\hline $\mathrm{JJ}$ & 6 & 0.38 & $\mathrm{X}$ & 4 & 0.26 \\
\hline JJJ & 6 & 0.38 & $\mathrm{XXX}$ & 2 & 0.13 \\
\hline \begin{tabular}{|l|}
$\mathrm{JJJJ}$ \\
\end{tabular} & 1 & 0.06 & XXXX & 1 & 0.06 \\
\hline JJJJJJ & 1 & 0.06 & $\mathrm{XXXXX}$ & 1 & 0.06 \\
\hline $\mathrm{K}$ & 12 & 0.77 & $\mathrm{Y}$ & 1 & 0.06 \\
\hline KKK & 9 & 0.57 & YY & 6 & 0.38 \\
\hline KKKK & 2 & 0.13 & YYYY & 1 & 0.06 \\
\hline $\mathrm{L}$ & 4 & 0.26 & YYYYY & 4 & 0.26 \\
\hline LL & 2 & 0.13 & $\mathrm{Z}$ & 143 & 9.12 \\
\hline LLL & 23 & 1.47 & $\mathrm{ZZ}$ & 4 & 0.26 \\
\hline LLLL & 2 & 0.13 & $\mathrm{ZZZ}$ & 5 & 0.32 \\
\hline $\mathrm{M}$ & 4 & 0.26 & ZZZZ & 3 & 0.19 \\
\hline MM & 1 & 0.06 & ZZZZZ & 1 & 0.06 \\
\hline MMM & 12 & 0.77 & Total & 1568 & $100 \%$ \\
\hline
\end{tabular}




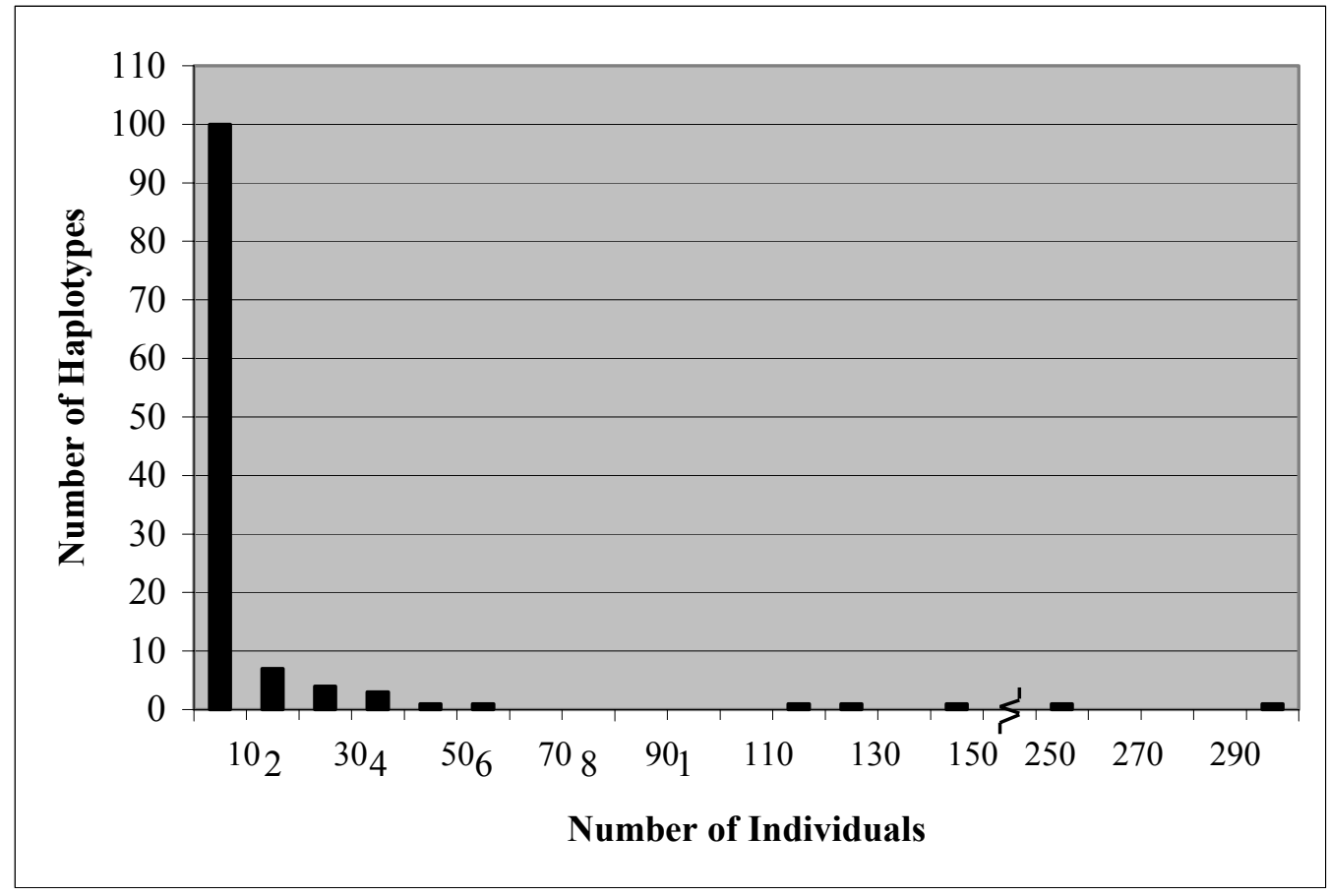

Fig. 2. Distribution of haplotype frequencies observed in 1,568 Steller sea lions rangewide. Note that the distribution is L-shaped.

\section{Measures of Genetic Distance}

Haplotype data were used to perform range-wide analyses of population structure. Exact tests of population subdivision, Slatkin's linearized F-statistics, and $\Phi$ statistics were calculated for all pairwise comparisons at rookery, region and stock population levels. The resulting matrix for the F- and $\Phi$-statistics for the rookery comparisons is provided in Appendix II.

Exact tests of population differentiation yielded largely significant values at all levels of comparisons. The numbers of significant pairwise comparisons $(P \leq 0.05)$ 


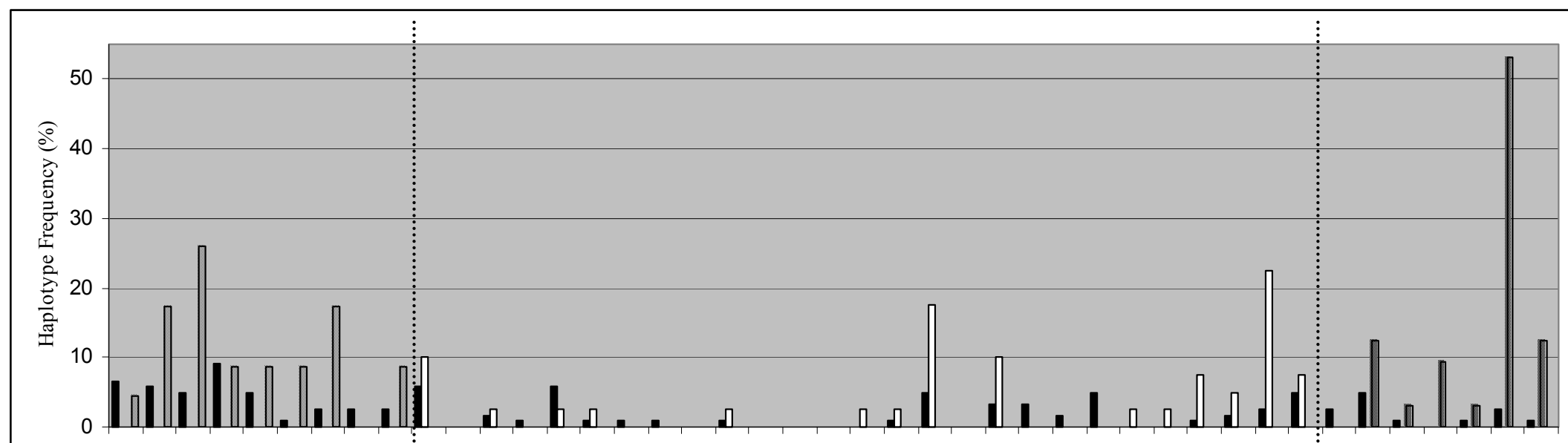

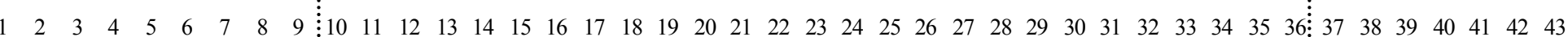
Asian Stock Western Stock

Rookery

- $\mathrm{A} \square \mathrm{DD} \square \mathrm{H} \square \mathrm{LLL}$

Eastern Stock

Note- Rookeries are listed according to longitude with the most westward rookery (Iony Island) listed to the left and the most eastward rookery (St. George Reef) placed at the far right. Only rookeries having a sample size of 10 or more were included in the figure. Rookery designations are as follows: $1=$ Iony, $2=$ Chernyye Brat'ya, $3=$ Srednego, $4=$ Raykoke, $5=$ Lovushki, 6 = Antsiferova, 7 = Yamsky, $8=$ Zheleznaya Bay, $9=$ Kozlova Cape, $10=$ Medney, $11=$ Attu, $12=$ Agattu, $13=$ Buldir, $14=$ Cape St. Stephen, $15=$ Lief Cove, $16=$ Amchitka, $17=$ Gramp Rock, $18=$ Kasatoshi, $19=$ Seguam, $20=$ Yunaska, $21=$ Adugak, $22=$ Ogchul, $23=$ Bogoslof, $24=$ Walrus, $25=$ Akutan, $26=$ Akun, $27=$ Ugamak, $28=$ Clubbing Rocks, $29=$ Pinnacle Rock, $30=$ Atkins, $31=$ Chowiet, $32=$ Chirikof, $33=$ Marmot, $34=$ Sugarloaf, $35=$ Fish, $36=$ Seal Rocks, $37=$ White Sisters, $38=$ Hazy, $39=$ Forrester, $40=$ North Danger Rocks, $41=$ Triangle, $42=$ Rogue Reef, $43=$ St. George Reef

Fig. 3. Distribution of four common D-loop haplotypes, A, DD, H, and LLL at the rookery level. 
were 537 of 903 comparisons of rookeries (59\%), 87 of 105 comparisons of regions $(83 \%)$, and 3 of 3 comparisons of stocks $(100 \%)$.

F- and $\Phi$-statistics were calculated for all pairwise comparisons (Appendix II). Among the 43 rookeries with $\mathrm{N} \geqq 10$, the numbers of significant pairwise comparisons $(P \leq 0.05)$ for $\mathrm{F}_{\mathrm{st}}$ were 468 of 903 comparisons $(51.8 \%)$, and for $\Phi_{\mathrm{st}}$ they were 549 of 903 comparisons $(61.0 \%)$. A neighbor-joining (NJ) tree was next constructed from the distance matrix (Fig. 4) using only the 43 rookeries with $\mathrm{N} \geqq 10$ (i.e., excluding Amak Island, Cape St. Elias, Chernabura Island, Chiswell Island, Latax Rocks, Ulak Island and Whaleback Island). The resultant tree exhibited some of the expected groupings. For instance, the eastern stock rookeries located along the coasts of British Columbia (BRC), Oregon (ORE), and northern California (NCA) formed a lineage distinct from all western stock rookeries. Rookeries from southeastern Alaska (SEA; White Sisters Islands, Hazy Islands, and Forrester Islands), however, are also expected to cluster with the eastern stock. Instead, SEA rookeries grouped closely with Asian rookeries from the Sea of Okhotsk (OKH), Kuril Islands (KUR), and Kamchatka Peninsula (KAM) at or near the base of the branch leading to all western stock rookeries.

The majority of Asian rookeries comprise a cluster with Hazy Islands (SEA) located near the base of the branch leading to the western stock rookeries. This branch does not include Antsiferova Island (KUR) and Kozlova Cape (KAM) which form a branch placed sister to rookeries belonging to the remaining western stock rookeries. Medney Island, the only rookery from the Commander Islands (COM), was placed 


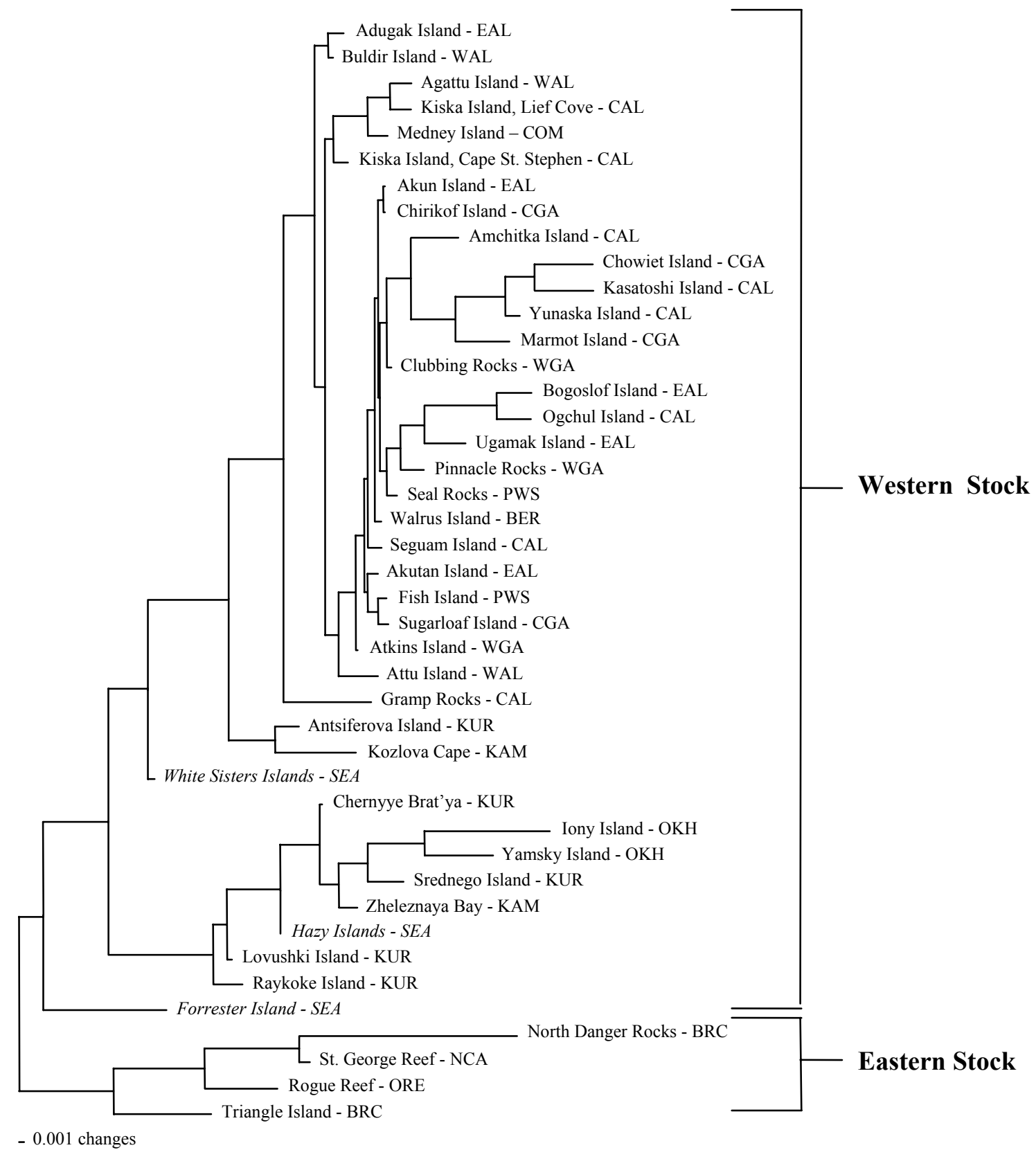

Note- Region designations are: $\mathrm{BER}=$ Bering Straight, $\mathrm{CAL}=$ Central Aleutian Islands, $\mathrm{CGA}=$ Central Gulf of Alaska, $\mathrm{EAL}=$ Eastern Aleutian Islands, WAL $=$ Western Aleutian Islands, WGA $=$ Western Gulf of Alaska, $\mathrm{COM}=$ Commander Islands, KUR $=$ Kuril Islands, $\mathrm{OKH}=$ Sea of Okhotsk, $\mathrm{KAM}=$ Kamchatka Peninsula, $\mathrm{BRC}=$ British Columbia, NCA $=$ Northern California, ORE $=$ Oregon, PWS = Prince William Sound, SEA = Southeastern Alaska. Forrester Island, Hazy Islands, and White Sisters Islands (italics) are also part of the Eastern Stock.

Fig. 4. Neighbor joining tree based on Slatkin's linearized $F_{\text {st }}$ (conventional) values at the rookery level. Note the presence of three eastern stock rookeries (italicized) on the western stock branch. 


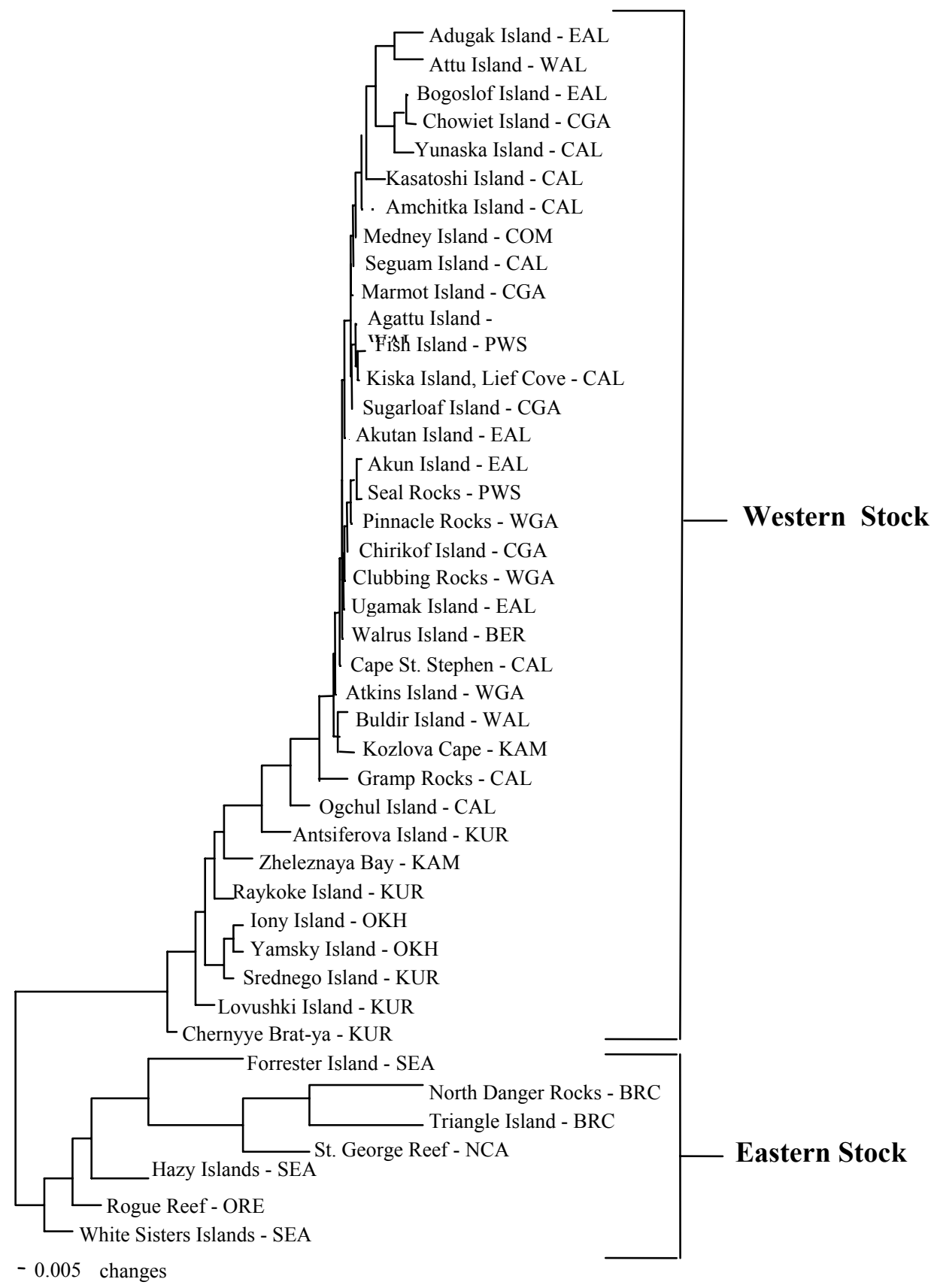

Note- Region designations are: $\mathrm{BER}=$ Bering Straight, $\mathrm{CAL}=$ Central Aleutian Islands, $\mathrm{CGA}=$ Central Gulf of Alaska, EAL $=$ Eastern Aleutian Islands, WAL $=$ Western Aleutian Islands, WGA $=$ Western Gulf of Alaska, $\mathrm{COM}=\mathrm{Commander}$ Islands, $\mathrm{KUR}=$ Kuril Islands, $\mathrm{OKH}=$ Sea of Okhotsk, $\mathrm{KAM}=$ Kamchatka Peninsula, $\mathrm{BRC}=$ British Columbia, $\mathrm{NCA}=$ Northern California, $\mathrm{ORE}=$ Oregon, PWS = Prince William Sound, SEA = Southeastern Alaska.

Fig. 5. Neighbor joining tree based on Slatkin's linearized $\mathrm{F}_{\mathrm{st}}$ analogues $\left(\Phi_{\mathrm{st}}\right)$ at the rookery level. 
among Alaskan western stock rookeries. All Alaskan western stock rookeries, plus Medney Island, comprise a single branch beginning with Gramp Rocks (Fig. 4).

The NJ tree constructed from the pairwise distance matrix of $\Phi_{\text {st }}$ values (Fig. 5) indicated strong divergence of eastern stock rookeries. Rookeries belonging to the western stock formed a single branch, with Asian rookeries occupying the most basal positions. Again, Medney Island (COM) was located well within the lineage among Alaskan western stock rookeries. Kozlova Cape also was nested among Alaskan western stock rookeries but was separated from the other Asian rookeries only by Gramp Rocks and Ogchul Island (both CAL), both of which are represented by small sample sizes $(\mathrm{N}=10)$.

Next, both F- and $\Phi$-statistics were calculated for all pairwise comparisons of the 15 sampled regions (Table 4). Using conventional F-statistics, 79.1\% of regional comparisons were significant $(\mathrm{P}<0.05)$ and $44.8 \%$ of those were highly significant ( $\mathrm{P}<0.001)$. A total of $72.4 \%$ of the $\Phi_{\text {st }}$ values were significant $(\mathrm{P}<0.05)$ among regional comparisons. This included $64.8 \%$ that were highly significant $(\mathrm{P}<0.001)$. For both $\mathrm{F}$ and $\Phi$-statistics, SEA, BRC, ORE and NCA were shown to be genetically divergent from all other non-eastern stock regions. KUR, OHK and KAM were also significantly different from nearly all other regions, while COM individuals were not significantly different from the nearby western and central Aleutian Islands.

As with the rookeries, $\mathrm{NJ}$ trees (Fig. 6) were constructed from the pairwise distance matrices generated in ARLEQUIN. The tree constructed from a matrix of conventional F-statistics indicated strong differentiation of regions from the eastern 
Table 4. Slatikin's linearized F-statistics (conventional $\mathrm{F}_{\mathrm{st}}$ above diagonal; $\mathrm{F}_{\mathrm{st}}$ analogues $\left(\Phi_{\mathrm{st}}\right)$ below diagonal) for all pairwise region comparisons based on mtDNA data.

Significant values $(\mathrm{P}<0.05)$ are in bold.

\begin{tabular}{|llllllllllllllll}
\hline & OKH & KUR & RUS & COM & WAL & CAL & EAL & WGA & CGA & BER & PWS & SEA & BRC & ORE & NCA \\
OKH & & $\mathbf{0 . 0 2}$ & $\mathbf{0 . 0 2}$ & $\mathbf{0 . 1 1}$ & $\mathbf{0 . 1 0}$ & $\mathbf{0 . 1 5}$ & $\mathbf{0 . 1 3}$ & $\mathbf{0 . 1 3}$ & $\mathbf{0 . 1 8}$ & $\mathbf{0 . 1 7}$ & $\mathbf{0 . 1 3}$ & $\mathbf{0 . 0 6}$ & $\mathbf{0 . 1 1}$ & $\mathbf{0 . 0 7}$ & $\mathbf{0 . 1 4}$ \\
KUR & $\mathbf{0 . 0 3}$ & & $\mathbf{0 . 0 2}$ & $\mathbf{0 . 0 6}$ & $\mathbf{0 . 0 5}$ & $\mathbf{0 . 0 8}$ & $\mathbf{0 . 0 7}$ & $\mathbf{0 . 0 7}$ & $\mathbf{0 . 1 1}$ & $\mathbf{0 . 0 9}$ & $\mathbf{0 . 0 7}$ & $\mathbf{0 . 0 2}$ & $\mathbf{0 . 0 7}$ & $\mathbf{0 . 0 5}$ & $\mathbf{0 . 0 9}$ \\
RUS & $\mathbf{0 . 0 4}$ & $\mathbf{0 . 0 5}$ & & $\mathbf{0 . 0 4}$ & $\mathbf{0 . 0 2}$ & $\mathbf{0 . 0 7}$ & $\mathbf{0 . 0 6}$ & $\mathbf{0 . 0 6}$ & $\mathbf{0 . 1 0}$ & $\mathbf{0 . 0 8}$ & $\mathbf{0 . 0 6}$ & $\mathbf{0 . 0 4}$ & $\mathbf{0 . 0 8}$ & $\mathbf{0 . 0 6}$ & $\mathbf{0 . 1 1}$ \\
COM & $\mathbf{0 . 1 3}$ & $\mathbf{0 . 1 1}$ & $\mathbf{0 . 0 3}$ & & 0.00 & 0.00 & $\mathbf{0 . 0 2}$ & $\mathbf{0 . 0 2}$ & $\mathbf{0 . 0 3}$ & 0.02 & $\mathbf{0 . 0 2}$ & $\mathbf{0 . 0 5}$ & $\mathbf{0 . 0 9}$ & $\mathbf{0 . 0 8}$ & $\mathbf{0 . 1 1}$ \\
WAL & $\mathbf{0 . 1 2}$ & $\mathbf{0 . 1 0}$ & 0.01 & 0.00 & & 0.00 & $\mathbf{0 . 0 1}$ & 0.01 & $\mathbf{0 . 0 2}$ & 0.01 & 0.01 & $\mathbf{0 . 0 5}$ & $\mathbf{0 . 0 9}$ & $\mathbf{0 . 0 8}$ & $\mathbf{0 . 1 1}$ \\
CAL & $\mathbf{0 . 1 2}$ & $\mathbf{0 . 1 0}$ & $\mathbf{0 . 0 3}$ & 0.00 & 0.00 & & $\mathbf{0 . 0 1}$ & $\mathbf{0 . 0 1}$ & $\mathbf{0 . 0 1}$ & 0.01 & $\mathbf{0 . 0 1}$ & $\mathbf{0 . 0 8}$ & $\mathbf{0 . 1 3}$ & $\mathbf{0 . 1 1}$ & $\mathbf{0 . 1 5}$ \\
EAL & $\mathbf{0 . 1 2}$ & $\mathbf{0 . 0 9}$ & $\mathbf{0 . 0 4}$ & $\mathbf{0 . 0 1}$ & 0.00 & $\mathbf{0 . 0 1}$ & & 0.00 & 0.00 & 0.00 & 0.00 & $\mathbf{0 . 0 7}$ & $\mathbf{0 . 1 1}$ & $\mathbf{0 . 1 0}$ & $\mathbf{0 . 1 3}$ \\
WGA & $\mathbf{0 . 1 3}$ & $\mathbf{0 . 0 8}$ & $\mathbf{0 . 0 4}$ & $\mathbf{0 . 0 3}$ & 0.01 & $\mathbf{0 . 0 2}$ & 0.00 & & 0.01 & 0.00 & 0.00 & $\mathbf{0 . 0 6}$ & $\mathbf{0 . 1 2}$ & $\mathbf{0 . 1 1}$ & $\mathbf{0 . 1 4}$ \\
CGA & $\mathbf{0 . 1 6}$ & $\mathbf{0 . 1 2}$ & $\mathbf{0 . 0 5}$ & $\mathbf{0 . 0 1}$ & 0.01 & 0.01 & 0.00 & 0.01 & & 0.00 & 0.00 & $\mathbf{0 . 1 0}$ & $\mathbf{0 . 1 6}$ & $\mathbf{0 . 1 4}$ & $\mathbf{0 . 1 8}$ \\
BER & $\mathbf{0 . 1 4}$ & $\mathbf{0 . 1 0}$ & 0.02 & 0.01 & 0.00 & 0.00 & 0.00 & 0.00 & 0.00 & & 0.00 & $\mathbf{0 . 0 8}$ & $\mathbf{0 . 1 2}$ & $\mathbf{0 . 1 1}$ & $\mathbf{0 . 1 4}$ \\
PWS & $\mathbf{0 . 1 4}$ & $\mathbf{0 . 0 9}$ & $\mathbf{0 . 0 4}$ & $\mathbf{0 . 0 2}$ & 0.01 & $\mathbf{0 . 0 1}$ & 0.01 & 0.01 & 0.01 & 0.00 & & $\mathbf{0 . 0 6}$ & $\mathbf{0 . 1 1}$ & $\mathbf{0 . 1 0}$ & $\mathbf{0 . 1 3}$ \\
SEA & $\mathbf{0 . 2 6}$ & $\mathbf{0 . 1 9}$ & $\mathbf{0 . 2 5}$ & $\mathbf{0 . 3 0}$ & $\mathbf{0 . 2 7}$ & $\mathbf{0 . 3 2}$ & $\mathbf{0 . 2 9}$ & $\mathbf{0 . 2 7}$ & $\mathbf{0 . 3 4}$ & $\mathbf{0 . 2 4}$ & $\mathbf{0 . 2 5}$ & & 0.02 & $\mathbf{0 . 0 1}$ & 0.01 \\
BRC & $\mathbf{0 . 4 8}$ & $\mathbf{0 . 3 5}$ & $\mathbf{0 . 4 8}$ & $\mathbf{0 . 4 8}$ & $\mathbf{0 . 5 0}$ & $\mathbf{0 . 5 1}$ & $\mathbf{0 . 4 8}$ & $\mathbf{0 . 5 0}$ & $\mathbf{0 . 5 9}$ & $\mathbf{0 . 4 6}$ & $\mathbf{0 . 4 4}$ & 0.01 & & $\mathbf{0 . 0 2}$ & 0.02 \\
ORE & $\mathbf{0 . 2 6}$ & $\mathbf{0 . 2 0}$ & $\mathbf{0 . 2 5}$ & $\mathbf{0 . 3 1}$ & $\mathbf{0 . 2 9}$ & $\mathbf{0 . 3 2}$ & $\mathbf{0 . 3 0}$ & $\mathbf{0 . 2 9}$ & $\mathbf{0 . 3 5}$ & $\mathbf{0 . 2 6}$ & $\mathbf{0 . 2 7}$ & 0.00 & 0.01 & \\
NCA & $\mathbf{0 . 3 9}$ & $\mathbf{0 . 2 6}$ & $\mathbf{0 . 3 6}$ & $\mathbf{0 . 3 7}$ & $\mathbf{0 . 3 8}$ & $\mathbf{0 . 3 9}$ & $\mathbf{0 . 3 5}$ & $\mathbf{0 . 3 8}$ & $\mathbf{0 . 4 5}$ & $\mathbf{0 . 3 5}$ & $\mathbf{0 . 3 1}$ & 0.00 & 0.00 & 0.00 & 0.00 \\
\hline
\end{tabular}

Note- Regional designations are as follows: OKH = Sea of Okhotsk; KUR = Kuril Islands; KAM = Kamkatcha Peninsula; COM = Commander Islands; WAL $=$ Western Aleutian Islands; $\mathrm{CAL}=$ Central Aleutian Islands; EAL $=$ Eastern Aleutian Islands; WGA $=$ Western Gulf of Alaska; CGA = Central Gulf of Alaska; BER = Bering Sea; PWS = Prince William Sound; SEA = Southeastern Alaska; $\mathrm{BRC}=$ British Columbia; ORE $=$ Oregon; $\mathrm{NCA}=$ Northern California.

stock. The Asian regions, KAM, KUR and $\mathrm{OKH}$, formed a branch which was placed sister to a clustering of Alaskan regions (the Aleutian Islands, Gulf of Alaska and PWS). Once again, COM was clustered among Alaskan western stock regions rather than among Asian regions. The NJ tree constructed from $\Phi$-statistics for the region level also indicated strong genetic differentiation of regions from the eastern stock. The Asian regions, KUR, OKH, and KAM, were shown to be closely related, although they did not form a separate branch. The Alaskan western stock regions formed a branch that included COM and which was placed sister to KAM.

Next, F- and $\Phi$-statistics were generated at the stock level. KAM, KUR, and OKH were placed in the Asian stock. COM, WAL, CAL, the eastern Aleutian Islands 
(A) Conventional $\mathrm{F}_{\text {st }}$ Values

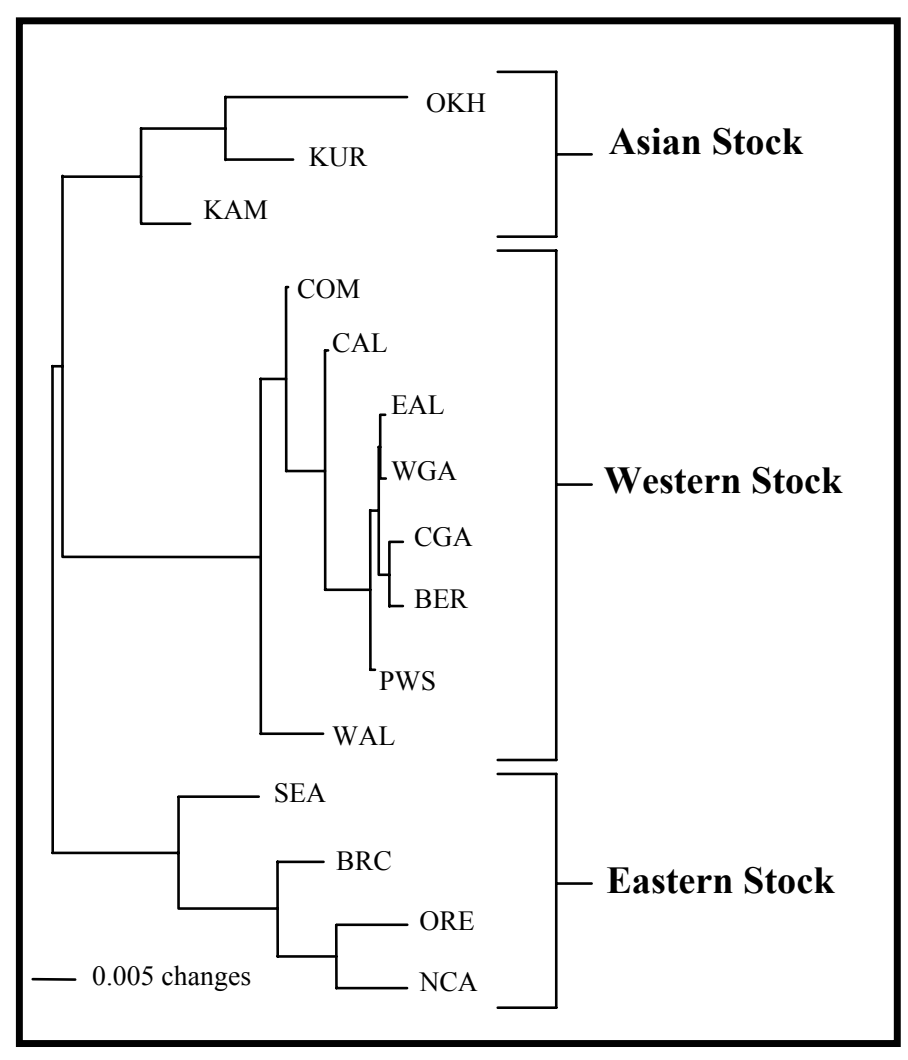

(B) $\mathrm{F}_{\mathrm{st}}$ Analogues $\left(\Phi_{\mathrm{st}}\right)$

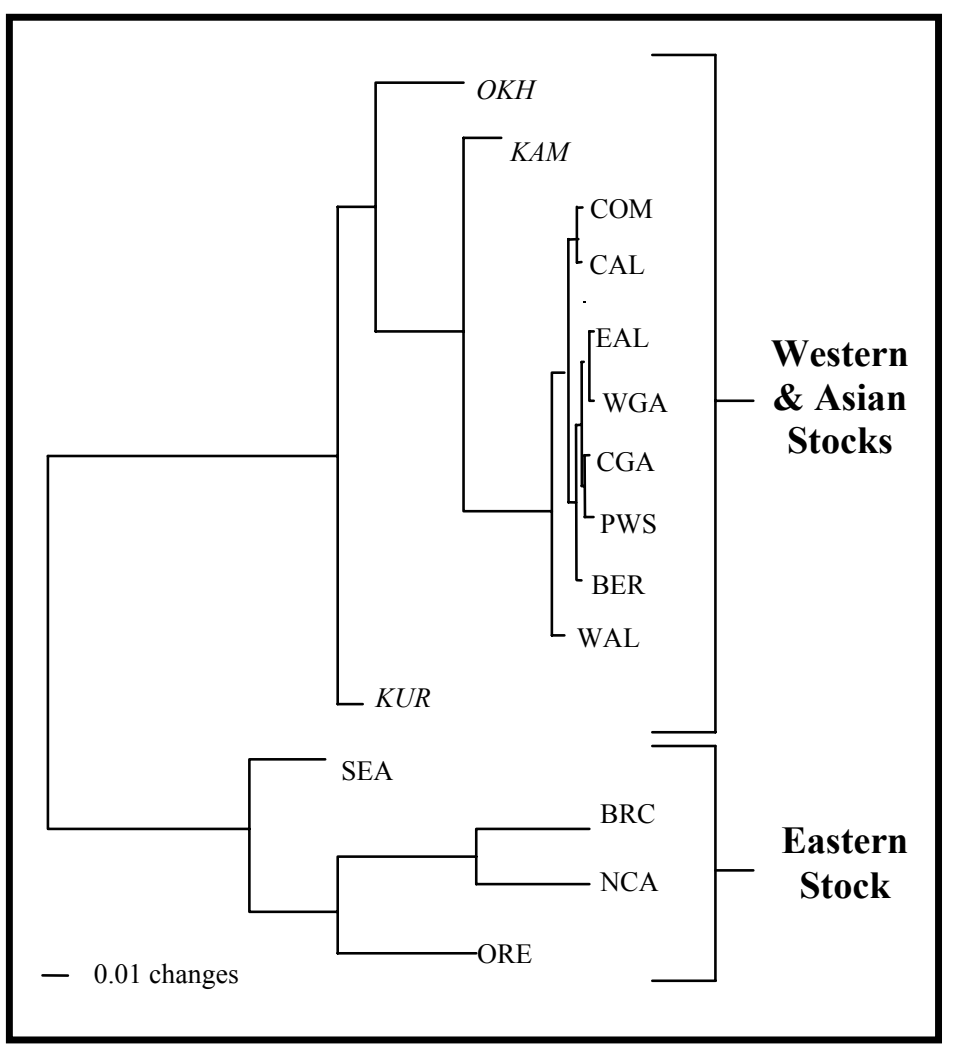

Note- Region designations are: $\mathrm{BER}=$ Bering Straight, $\mathrm{CAL}=\mathrm{Central}$ Aleutian Islands, $\mathrm{CGA}=$ Central Gulf of Alaska, EAL $=$ Eastern Aleutian Islands, $\mathrm{WAL}=\mathrm{Western}$ Aleutian Islands, WGA $=$ Western Gulf of Alaska, $\mathrm{COM}=$ Commander Islands, $\mathrm{KUR}=$ Kuril Islands, $\mathrm{OKH}=$ Sea of Okhotsk, KAM $=$ Kamchatka Peninsula, $\mathrm{BRC}=\mathrm{British}$ Columbia, NCA $=$ Northern California, ORE $=$ Oregon, PWS $=$ Prince William Sound, SEA = Southeastern Alaska.

Fig. 6. Neighbor joining trees based on Slatkin's linearized F-statistics at the region level. 
(A) Conventional $F_{\text {st }}$ Values

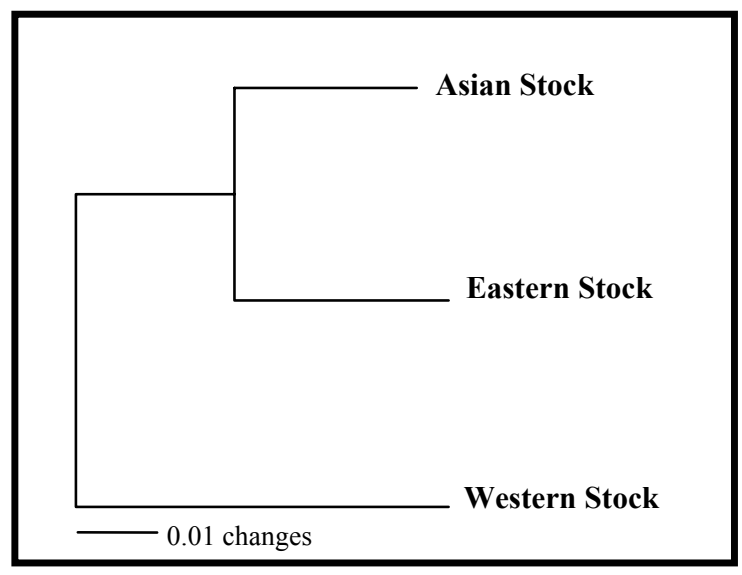

(B) $\mathrm{F}_{\text {st }}$ Analogues $\left(\Phi_{\text {st }}\right)$

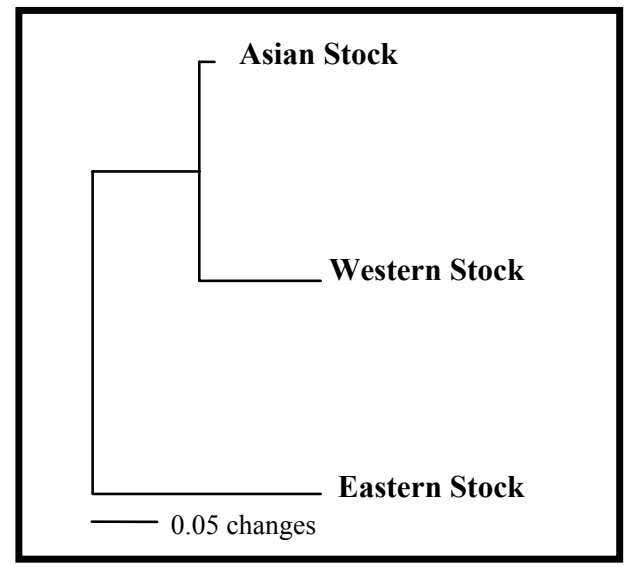

Fig. 7. Neighbor joining trees based on Slatkin's linearized F-statistics at the stock level. Note that the relationship between stocks differs depending on which analysis is applied.

(EAL), Bering Sea (BER), western Gulf of Alaska (WGA), central Gulf of Alaska (CGA) and PWS were placed in the western stock. SEA, BRC, ORE and NCA comprised the eastern stock. All pairwise comparisons yielded highly significant (P $<<0.001) \mathrm{F}_{\text {st }}$ values of 0.0838 (Asian-western), 0.0887 (western-eastern), and 0.0463 (Asian-eastern). The NJ tree constructed from these values (Fig. 7), suggested that the Asian stock was more closely related to the eastern stock than to the geographically adjacent western stock. All three $\Phi_{\text {st }}$ values were significant $(\mathrm{P}<<0.001$; Asian-western $=0.0809$, Asian-eastern $=0.241$, western-eastern $=0.339)$, and the NJ tree suggested that the Asian and western stocks were more closely related to one another than to the eastern stock.

The test for isolation by distance revealed no significant linear correlation between geographic distances and genetic distances $\left(\mathrm{F}_{\mathrm{st}}\right.$ and $\Phi_{\mathrm{st}}$ values $)$ at the rookery 
level. In fact, the null hypothesis (random distribution of data points with no linear correlation between genetic and geographic distances) was supported by the data $(\mathrm{P} \leq$ 0.0001). However, when comparisons were restricted to rookeries of the same stock, all tests revealed significant linear correlation except one. The Asian stock rookeries showed no significant correlation between $\mathrm{F}_{\text {st }}$ and geographic distance (support for $\mathrm{H}_{0}, \mathrm{P}$ $\leq 0.05)$. However, there was a significant correlation between $\Phi_{\text {st }}$ and geographic distance. To determine if the highly distinct eastern stock populations were driving this effect, the analysis was performed on the combined western stock and Asian stock rookeries. No significant correlation between geographic distance and genetic distance was observed for either $\mathrm{F}_{\mathrm{st}}$ or $\Phi_{\mathrm{st}}$.

Maximum likelihood estimates of $\mathrm{N} m$ were next obtained using the program MIGRATE. Given the $\mathrm{F}_{\mathrm{st}}$ and $\Phi_{\mathrm{st}}$ results provided above, three stocks (or populations) were assumed including the Asian stock (OKH, KUR, and KAM), the western stock (COM, WAL, CAL, EAL, BER, WGA, CGA, PWS), and the eastern stock (SEA, BRC, ORE, NCA). Migration rates between stocks (number of effective migrants per generation, $\mathrm{N} m$ ) were as follows: western to Asian $95 \%$ confidence interval of 11.5 to 18.9 with a best estimate of 14.8 , Asian to western $95 \%$ confidence interval of 11.7 to 18.0 with a best estimate of 14.6 , eastern to Asian $95 \%$ confidence interval of 0.133 to 0.854 with a best estimate of 0.177 , Asian to eastern $95 \%$ confidence interval of 1.01 to 4.36 with a best estimate of 2.72 , eastern to western $95 \%$ confidence interval of 0.756 to 2.73 with a best estimate of 1.54 , and western to eastern $95 \%$ confidence interval of 1.66 to 5.32 with a best estimate of 3.19 . Thus, there was an average migrant exchange of 
14.7 females per generation between the Asian and western stocks, 1.45 females per generation between the eastern and Asian stocks, and 2.37 females per generation between the western and eastern stocks.

Migration rates between stocks were also calculated from F- and $\Phi$-statistics. The number of female migrants per generation estimated from F-statistics was 5.97 between the Asian and western stocks, 10.8 between the Asian and eastern stocks, and 5.64 between the eastern and western stocks. Likewise, the number of female migrants estimated from $\Phi$-statistics was 6.18 between the Asian and western stocks, 2.07 between the Asian and eastern stocks, and 1.48 between the eastern and western stocks. 


\section{DISCUSSION}

\section{Mitochondrial Control Region Diversity}

To date, 145 haplotypes have been reported for a 238 bp segment of the Steller sea lion mitochondrial control region (J. W. Bickham, pers. comm.). Of these, 121 were found in pups sampled at their natal rookery (Table 3) and the rest have only been observed in scats, or in juveniles or adults for which the rookery of origin is unknown. It is reasonable to assume that more haplotypes will be identified as sample sizes increase. Thus, the high haplotypic diversity observed range-wide $(H=0.9164 \pm 0.0035)$ was expected, and a similar degree of diversity has been reported for the mitochondrial control region of other marine mammals, including harbor seals, Phoca vitulina, $(\mathrm{H}=$ 0.975; Westlake \& O'Corry-Crowe, 2002) and Dall's porpoise, Phocoenoides dalli, $(\mathrm{H}=$ 0.96; Escorza-Trevino \& Dizon, 2000). Previous reports for haplotype (nucleon) diversity for various rookeries and regions in Steller sea lions were similar to those found here (Bickham, 1996; Bickham et al., 1998a, 1998b). Furthermore, the moderately low nucleotide diversity observed ( $\pi=0.00967 \pm 0.00596)$ is consistent with the vast majority of haplotypes differing by a single substitution event from one or more haplotypes (J. W. Bickham, pers. comm.). Despite the recent decline in numbers of Steller sea lions, mtDNA haplotype diversity does not seem to have been appreciably reduced. The L-shaped distribution of haplotype frequencies (Fig. 2) provides strong evidence for an absence of bottleneck effects on haplotype diversity (Luikart et al., 1998). Likewise, the high range-wide haplotype diversity estimate is comparable to other marine mammals (cetaceans) which have not experienced a bottleneck (Rooney et 
al., 2001). Nucleotide diversity in Steller sea lions is intermediate between whale populations that have bottlenecked and those that have not (Rooney et al., 2001).

\section{Phylogeography}

Although most haplotypes occurred at a frequency of less than 10\% (Table 3), several were quite common. The most common haplotypes were S (18.2\%) and BB (15.9\%). Two haplotypes (A and BB) were distributed throughout the entire species range whereas most were restricted to certain regions. For example, haplotypes LLL, DD and $\mathrm{H}$ were restricted to the Asian, western and eastern stocks, respectively (Fig. 3). The geographic partitioning of various haplotypes resulted in definite patterns of population subdivision at both the rookery and region levels. Despite the generally high sample size in this study, resolution of population substructure increased when rookeries were grouped into their respective regions. One possible reason for this is a sample-size effect. Eastern stock rookeries, or those rookeries belonging to SEA, BRC, ORE, and NCA, were clearly differentiated from all other rookeries when using $\Phi$-statistics (Fig. 4). Differentiation of eastern stock rookeries was less clear when conventional Fstatistics were applied (Fig. 5). The NJ tree constructed at the regional level using conventional F-statistics resolved three distinct lineages, whereas, the tree constructed from $\Phi$-statistics resolved only two separate lineages, although Asian regions clearly occupied the most basal positions and were genetically differentiated from all other groups (Fig. 6). 
All analyses placed Medney Island, the only rookery of the Commander Islands (COM), with Alaskan western stock rookeries rather than with Asian rookeries. This result is opposite of that predicted by Trujillo et al. (in press) and parallels a similar relationship reported along the Commander-Aleutian Island chain for sea otters (Cronin et al., 1996) and harbor seals (Westlake and O'Corry-Crowe, 2002). F $\mathrm{F}_{\text {st }}$ estimates do a good job at isolating the Alaskan western stock from the eastern stock and from the Asian rookeries (Fig. 4). This analysis shows Medney Island to be part of the Alaskan western stock. Since this rookery is of recent origin, beginning in 1972 (Mamaev and Burkanov, 1996), it is clear that it must have been founded by immigrants from Alaska, not from Asia. This arrangement is supported in all assessments of rookeries and regions (Figs. 4-6). The present study includes a larger sample size from Medney Island $(\mathrm{N}=106)$ than was available to Trujillo et al. (in press; $\mathrm{N}=10$ ).

Given the $\mathrm{F}_{\mathrm{st}}$ and $\Phi_{\mathrm{st}}$ results obtained at the rookery and region levels, three populations were assumed for analyses of stock structure, the Asian, western, and eastern stocks. COM fell within the western stock for all analyses at the stock level. All $\mathrm{F}_{\mathrm{st}}$ and $\Phi_{\mathrm{st}}$ values were significant supporting the recognition of three stocks, although the relationships between stocks differed between analyses (Fig. 7). The currently recognized eastern stock would be unaltered, but the western stock should be partitioned west of the Commander Islands yielding a western stock which ranges from Prince William Sound west to the Commander Islands, and an Asian stock including rookeries from the Kamchatka Peninsula, Kuril Islands, and Sea of Okhtosk (Fig. 1). 
Analyses of isolation by distance indicated significant linear correlations between measures of genetic distance and geographic distance among rookeries (with one exception), but only when rookeries within stocks are considered. These results support the partitioning of the range of Steller sea lions into three genetically differentiated stocks, each of which contain a number of populations (rookeries) that follow an isolation by distance model of population subdivision. The zones of contact between the Asian and western stocks and between the eastern and western stocks likely do not represent barriers to gene flow. Rather they are the historical points of contact of three expanding populations that have adjusted their ranges in response to increased habitat availability since the last glaciation.

$\underline{\text { Inter- }} \underline{\text { and }} \underline{\text { Intra-Stock }} \underline{\text { Patterns }} \underline{\text { of Migration and }} \underline{\text { Stock }} \underline{\text { Structure }}$ Maximum likelihood estimation of $\mathrm{N}_{\mathrm{f}} m$ revealed a level of migrant exchange between the western and Asian stocks that was roughly 10 times the rate of exchange between the Asian and eastern stocks and approximately 6 fold greater than the exchange between the western and eastern stocks. Such low levels of mitochondrial gene flow occurring between Asian and eastern and especially between western and eastern stocks explain the distinct differentiation of eastern stock rookeries and regions observed when running $\mathrm{F}_{\mathrm{st}}$ and $\Phi_{\mathrm{st}}$ analyses. In fact, all inter-stock migration rates were generally low, which is consistent with the relatively high degree of natal site fidelity thought to characterize this species. It is likely that female interchange among rookeries within stocks is relatively high, at least over evolutionary time scales. This can be 
inferred from the fact that the NJ trees of rookeries show relatively little concordance with geographic distribution (Figs. 4 and 5). However, NJ trees based on regions tend to more precisely reflect geographic distributions, especially using conventional $\mathrm{F}_{\mathrm{st}}$ estimates (Fig. 6a). In Fig. 6a the arrangements of the regions precisely reflect their geographic relationships within both the Asian and eastern stocks. Among the western stock regions the relationship is not quite perfect but the most western regions (WAL, COM, and CAL) are the most basal and the eastern-most regions form a tight cluster at the tip. It is also apparent that western stock regions generally show shorter branch lengths than do the eastern stock and Asian stock regions (Fig. 6a). This is especially true for the $\Phi_{\text {st }}$ estimates (Fig. 6b). This likely reflects high exchange of migrants among the rookeries of the eastern-most western stock regions (from Prince William Sound to the eastern Aleutian Islands and the Bering Sea).

Estimates of migrant exchange obtained from $\mathrm{F}_{\mathrm{st}}$ and $\Phi_{\mathrm{st}}$ analyses in some cases differed significantly from maximum-likelihood estimates (MLE). For instance, the average of the MLE of female migrants exchanged between the Asian stock and the western stock was at least twice as high as the rates obtained from both $\mathrm{F}_{\text {st }}$ and $\Phi_{\text {st }}$ estimates. The values estimated from $\Phi$-statistics for the Asian-eastern and westerneastern migrant exchange, however, were similar to MLE whereas the rates of exchange estimated from F-statistics were unlike those obtained using either the maximumlikelihood approach or those estimated from $\Phi$-statistics. Obviously, more modeling is needed to determine which approach is best for estimation of migration rates. Still, MLE appear to be the most logical, indicating the highest level of gene flow occurring 
between the Asian and western stocks and low levels of exchange occurring between the eastern stock and both the western and Asian stocks.

Patterns of population subdivision (stock structure) result from historical processes, mutation, genetic drift, and current patterns of migration (Avise, 1994). The high degree of differentiation of the eastern stock likely reflects some or all of these processes. The eastern stock haplotypes form a well differentiated network in the phylogenetic analyses (J. W. Bickham, pers. comm.) which might explain why the NJ tree based on estimates of $\Phi_{\mathrm{st}}$ shows longer branch lengths leading to the eastern stock regions (Fig. 6b). The eastern stock is also well differentiated by haplotype frequencies alone (Fig. 6a). It was suggested that the eastern stock likely differentiated from the western stock as a result of isolation in different Pleistocene glacial refugia (Bickham et al., 1996). The fact that two other species of marine mammals, harbor seals (Westlake and O'Corry-Crowe, 2002) and sea otters (Cronin et al., 1996) show a major break between populations east and west of $144^{\circ} \mathrm{W}$ supports this conclusion. Such genealogical concordance involving shared phylogeographic patterns among unrelated species with similar distributions is presumably the result of similar historic influences on the intraspecific genetic architecture (Avise, 1994). Likewise, sockeye salmon (Onchorhynchus nerka), which have a similar distribution to Steller sea lions, were hypothesized to have been isolated in Pleistocene glacial refugia in Beringia and the Pacific Northwest (Columbia River; Lindsey and McPhail, 1986; McPhail and Lindsey, 1970, 1986). The differentiation of the southernmost populations, presumably descended from the Pacific Northwest refugium, and the northern populations, 
presumably from the Beringian refugium, was well supported by allozyme and mtDNA data (Bickham et al., 1995). 


\section{CONCLUSIONS}

Mitochondrial DNA analysis supports the recognition of three stocks, the Asian, western and eastern stocks, in Steller sea lions. Medney Island, the only rookery of the Commander Island chain (COM), is placed within the western, rather than within the Asian stock. Generally, low rates of migration were estimated among stocks. Higher rates of migrant exchange were estimated between the Asian and western stocks, than between the eastern and western stocks. This is consistent with the conclusion that the major phylogeographic break within the species is between the eastern and western stocks. Estimates of population subdivision based on $\mathrm{F}_{\mathrm{st}}$ and $\Phi_{\mathrm{st}}$ at the rookery and region levels support this conclusion, as do patterns of among-stock migration and isolation by distance. 


\section{LITERATURE CITED}

Albers, P. H. and T. R. Loughlin. 2003. Effects of PAHs on marine birds, mammals, and reptiles. Pp. 243-261 in PAHs an Ecotoxicological perspective, John Wiley \& Sons, Ltd., London.

Alverson, D. L. 1998. The Steller sea lion and pollock- changing perspectives. Unpublished manuscript. Fisheries Research Institute FRI-UW-9106, University of Washington, WH-10, Seattle, Washington, 98105.

Amos, B. and A. R. Hoelzel. 1991. Long-term preservation of whale skin for DNA analysis. Report of the International Whaling Commission Special Issue 13:99103.

Anonymous. 1995. Status review of the United States Steller sea lion (Eumetopias jubatus) populations. Unpublished report prepared by the National Marine Mammal Laboratory, National Marine Fisheries Service, 61p.

Avise, J. C. 1994. Molecular markers, natural history and evolution. Chapman \& Hall, New York.

Beerli, P. 1997-2002. MIGRATE: documentation and program, part of LAMARC. Version 1.5. Revised August 7, 2002. Distribution over the Internet, http://evolution.genetics.washington.edu/lamarc.html. [Downloaded: June 7, 2003].

Bickham, J. W., T. R. Loughlin, D. G. Calkins, J. K. Wickliffe, and J. C. Patton. 1998a. Genetic variability and population decline in Steller sea lions from the Gulf of Alaska. Journal of Mammalogy 79:1390-1395.

Bickham, J. W., T. R. Loughlin, J. K. Wickliffe, and V. N. Burkanov. 1998 b. Geographic variation in the mitochondrial DNA of Steller sea lions: haplotype diversity and endemism in the Kuril Islands. Bioshpere Conservation 1:107117.

Bickham, J. W., J. C. Patton, and T. R. Loughlin. 1996. High variability for controlregion sequences in a marine mammal: implications for conservation and biogeography of Steller sea lions (Eumetopias jubatus). Journal of Mammalogy 77:95-108.

Bickham, J. W., C. C. Wood, and J. C. Patton. 1995. Variation in mitochondrial cytochrome $\underline{\mathrm{b}}$ sequences and allozymes in sockeye (Oncorhynchus nerka). Journal of Heredity 86:140-144. 
Calkins, D. G., E. Becker, T. R. Spraker, and T. R. Loughlin. 1994. Impacts on Steller sea lions. Pp. 119-139 in Marine mammals and the Exxon Valdez, Academic Press, San Diego, California.

Casgrain, P. and P. Legendre. 2001. The R Package for Multivariate and Spatial Analysis, version 4.0d5-User's Manual. Department de sciences biologiques. Universite de Montreal. Available on the WWWeb site $<$ http://www.fas.umontreal.ca/BIOL/legendre $>$

Cronin, M. A., J. Bodkin, B. Ballachey, J. Estes, and J. C. Patton. 1996. MitochondrialDNA variation among subspecies and populations of sea otters (Enhydra lutris). Journal of Mammalogy 77:546-557.

Escorza-Trevino, S. and A. E. Dizon. 2000. Phylogeography, intraspecific structure and sex-biased dispersal of Dall's porpoise, Phocoenoides dalli, revealed by mitochondrial and microsatellite DNA analyses. Molecular Ecology 9:10491060

Excoffier, L., P. E. Smouse, and J. M. Quattro. 1992. Analysis of molecular variance inferred from metric distances among DNA haplotypes: application to human mitochondrial DNA restriction data. Genetics 131:479-491.

Gentry, R. L. and D. E. Withrow. 1986. Steller sea lion. Pp. 188-194 in Marine Mammals. $2^{\text {nd }}$ ed. Pacific Search Press, Seattle, Washington.

Hartl, D. L. and A. G. Clark. 1997. Principles of Population Genetics. Sinauer and Associates, Inc., Sunderland, Massachusetts.

Haynes, T. L., and C. Mishler. 1994. The subsistence harvest and use of Steller sea lions in Alaska. Alaska Department of Fish and Game Technical Paper 198:144.

Hedrick, P. W. 2000. Genetics of Populations. $2^{\text {nd }}$ ed. Jones and Bartlett Publishers, Inc., Sudburry, Massachusetts.

Helling, H. E. 1984. A follow-up report on available data for California and Steller sea lion (Zalophus californianus, Eumetopias jubatus) exploitation prior to 1950. Southwest Fisheries Center Administration Report LJ-84-45C:1-10.

Honeycutt, R. 2000. Genetic applications for large mammals. Pp. 233-259 in Ecology and management of large mammals in North America, Prentice-Hall, Inc., Upper Saddle River, New Jersey. 
Kenyon, K. W., and D. W. Rice. 1961. Abundance and distribution of the Steller sea lion. Journal of Mammalogy 42:223-234.

Kim, G. B., J. S. Lee, S. Tanabe, H. Iwata, R. Tatsukawa, and K. Shimazaki. 1996 a. Specific accumulation and distribution of butyltin compounds in various organs and tissues of the Steller sea lion (Eumetopias jubatus): comparison with organochlorine accumulation pattern. Marine Pollution Bulletin 32:558-563.

Kim, G. B., S. Tanabe, R. Tatsukawa, T. R. Loughlin, and K. Shimazaki. $1996 \mathrm{~b}$. Characteristics of butyltin accumulation and its biomagnification in Steller sea lion (Eumetopias jubatus). Environmental Toxicology and Chemistry 15:20432048 .

Lee, J. S., S. Tanabe, H. Umino, R. Tatsukawa, T. R. Loughlin, and D. C. Calkins. 1996. Persistent organochlorines in Steller sea lion (Eumetopias jubatus) from the bulk of Alaska and the Bering Sea, 1976-1981. Marine Pollution Bulletin 32:535-544.

Lidicker, Jr., W. Z., R. D. Sage and D. G. Calkins. 1981. Biochemical variation in northern sea lions from Alaska. Pp. 231-244 in Mammalian population genetics, University of Georgia Press, Athens.

Lindsey, C. C. and J. D. McPhail. 1986. Zoogeography of fishes of the Yukon and Mackenzie basin. Pp. 639-674 in Zoogeography of North American freshwater fishes, John Wiley \& Sons, New York.

Loughlin, T.R. 1997. Using the phylogeographic method to identify Steller sea lion stocks. Pp. 159-171 in Molecular genetics of marine mammals. Society of Marine Mammalogy, Special Publication 3.

Loughlin, T. R. 1998. The Steller sea lion: a declining species. Bioshpere Conservation 1:91-98.

Loughlin, T. R., B. E. Ballachey, and B. A. Wright. 1996. Overview of studies to determine injury caused by the Exxon Valdez oil spill to marine mammals. Pp. 798-808 in Proceedings of the Exxon Valdez oil spill symposium. American Fisheries Society Symposium 18.

Loughlin, T.R., A.S. Perlov, and V.A. Vladimirov. 1984. Northern sea lion distribution and abundance: 1956-1980. Journal of Wildlife Management 48:729-740.

Loughlin, T. R., A. S. Perlov, and V. A. Vladimirov. 1992. Range-wide survey and estimation of total number of Steller sea lions in 1989. Marine Mammal Science $8: 220-239$. 
Loughlin, T. R. and A. E. York. 2000. An accounting of the sources of Steller sea lion, Eumetopias jubatus, mortality. Marine Fisheries Review 62:40-45.

Lowry, L. F., K. J. Frost, and T. R. Loughlin. 1988. Importance of walleye pollock in the diets of marine mammals in the Gulf of Alaska and Bering Sea, and implications for fishery management. Pp. 701-725 in Proceedings of the international symposium on the biology and management of walleye pollock, Nov. 14-16, 1988, Anchorage, Alaska. Alaska Sea Grant Report 89-1.

Luikart, G., F. W. Allendorf, J. M. Cornuet, and W. B. Sherwin. 1998. Distortion of allele frequency distributions provides a test for recent population bottlenecks. J. Hered. 89:238-247.

Mamaev, E. G. and V. N. Burkanov. 1996. Condition of representative groups of Steller sea lions, Eumetopias jubatus (Pinnipedia, Otariidae) on Southeast rookery of Mednyy Island (Commander Island). Izvestiya of the Pacific Research Institute of Fisheries and Oceanography (TINRO) 121:163-165.

Maniatis, T.E., E.F. Fristch, and J. Sambrook. 1982. Molecular cloning: a laboratory manual. Cold Spring Harbor Publications, New York.

Mantel, N. 1967. The detection of disease clustering and generalized regression approach. Cancer Research 27:209-220.

Mate, B. 1976. History and present status of the Northern (Steller) sea lion, Eumetopias jubatus. Unpublished manuscript, 6p. Available Alaska Fisheries Science Center, 7600 Sand Point Way NE., Seattle, Washington 98115.

McPhail, J. D. and C. C. Lindsey. 1970. Freshwater fishes of northwestern Canada and Alaska. Fish. Res. Board Can. Bull. 173:1-381.

McPhail, J. D. and C. C. Lindsey. 1986. Zoogeography of freshwater fishes of Cascadia (the Columbia system and rivers north to the Stikine). Pp. 615-637 in Zoogeography of North American freshwater fishes, John Wiley \& Sons, New York.

Nei, M. and F. Tajima. 1981. DNA polymorphism detectable by restriction endonucleases. Genetics 97:145-163.

Nei. M. 1987. Molecular Evolutionary Genetics. Columbia University Press, New York. 
Pascual, M. A. and M. D. Adkison. 1994. The decline of the Steller sea lion in the northeast pacific: demography, harvest or environment? Ecological Applications 4:393-403.

Raymond and Rousset. 1995. An exact test for population differentiation. Evolution 49:1280-1283.

Rooney, A. P., R. L. Honeycutt, and J. N. Derr. 2001. Historical population size change of bowhead whales inferred from DNA sequence polymorphism data. Evolution 55:1678-1685.

Saeki, K., M. Nakajima, K. Noda, T. R. Loughlin, N. Baba, M. Kiyota, R. Tatsukawa, and D. G. Calkins. 1999. Vanadium accumulation in pinnipeds. Archives of Environmental Contamination and Toxicology 36:81-86.

Schneider, S., D. Roessli, and L. Excoffier. 2000. ARLEQUIN. A software for population genetics data analysis. Version 2.0. Genetics and Biometry Lab, Dept. of Anthropology, University of Geneva, Geneva Switzerland. URL: http://anthro.unige.ch/arlequin.

Sease, J. L., and C. J. Gudmundson. 2002. Aerial and land-based surveys of Steller sea lions (Eumetopias jubatus) from the western stock in Alaska, June and July 2001 and 2002. U. S. Dep. Commer., NOAA Tech. Memo. NMFS-AFSC-131:1-45.

Sease, J. L., W. P. Taylor, T. R. Loughlin, and K. W. Pitcher. 2001. Aerial and landbased surveys of Steller sea lions (Eumetopias jubatus) in Alaska, June and July 1999 and 2000. U.S. Dep. Commer., NOAA Tech. Memo. NMFS-AFSC-122:152.

Slatkin, M. 1995. A measure of population subdivision based on microsatellite allele frequencies. Genetics 139:457-462.

Swofford, D. L. 1998. PAUP*. Phylogenetic analysis using parsimony (*and other methods). Version 4. Sinauer Associates, Sunderland, Massachusetts.

Sydeman, W. J. and W. M. Jarman. 1998. Trace metal in seabirds, Steller sea lions, and forage fish and zooplankton from central California. Marine Pollution Bulletin $36: 828-832$.

Tamura, L. and M. Nei. 1993. Estimation of the number of nucleotide substitutions in the control region of mitochondrial DNA in humans and chimpanzees. Molecular Biology and Evolution 10:512-526. 
Trites, A. W., P. Livingston, M. C. Vasconcellos, S. Mackinson, A. M. Springer and D. Pauly. 1999. Ecosystem considerations and the limitations of ecosystem models in fisheries management: insights from the Bering Sea. Pp. 609-619 in Proceedings of ecosystem considerations in fisheries management. Sixteenth Lowell Wakefield Fisheries Symposium and American Fisheries Society joint meeting. Anchorage, Alaska, USA. September 30-October 3, 1998. Alaska College Sea Grant Program AK-SG-99-01.

Trujillo, R. G, T. R. Loughlin, N. J. Gemmell, J. C. Patton, and J. W. Bickham. In press. Variation in microsatellite and mtDNA across the range of the Steller sea lion, Eumetopias jubatus. Journal of Mammalogy.

Westlake, R. L. and G. M. O'Corry-Crowe. 2002. Macrogeographic structure and patterns of genetic diversity in harbor seals (Phoca vitulina) from Alaska to Japan. Journal of Mammalogy 83:1111-1126.

Wright, S. 1951. The genetical structure of populations. Annals of Eugenics 15:323354.

York, A. E. 1994. The population dynamics of Northern sea lions, 1975-1985. Marine Mammal Science 10:38-51. 


\section{APPENDIX I}

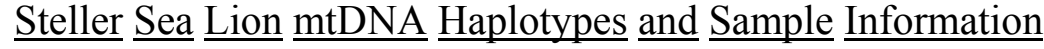

\begin{tabular}{|c|c|c|c|c|c|c|c|}
\hline Stock & Region & Rookery & Sample & Date Collected & Weight (kg) & Sex & Haplotype \\
\hline Asian & Kamchatka & Kozlov C. & K219 & 5-Jul-02 & 31.0 & $\mathrm{~F}$ & $\mathrm{~A}$ \\
\hline Asian & Kamchatka & Kozlov C. & K236 & 5-Jul-02 & 23.0 & $\mathrm{~F}$ & $\mathrm{~A}$ \\
\hline Asian & Kuril Islands & Antsiferov Island & Y483 & 26-Jun-01 & - & - & $\mathrm{A}$ \\
\hline Asian & Kuril Islands & Chernyye Brat'ya & Br610 & 7-Jul-01 & - & - & $\mathrm{A}$ \\
\hline Asian & Kuril Islands & Chernyye Brat'ya & Br612 & 7-Jul-01 & - & - & $\mathrm{A}$ \\
\hline Asian & Kuril Islands & Chernyye Brat'ya & Br617 & 7-Jul-01 & - & - & $\mathrm{A}$ \\
\hline Asian & Kuril Islands & Lovushki Island & Lr415 & 1-Jul-01 & - & - & $\mathrm{A}$ \\
\hline Asian & Kuril Islands & Lovushki Island & $\mathrm{Lr} 424$ & 1-Jul-01 & - & - & $\mathrm{A}$ \\
\hline Asian & Kuril Islands & Lovushki Island & Lr429 & 1-Jul-01 & - & - & $\mathrm{A}$ \\
\hline Asian & Kuril Islands & Lovushki Island & $\mathrm{Lr} 437$ & 1-Jul-01 & - & - & $\mathrm{A}$ \\
\hline Asian & Kuril Islands & Lovushki Island & $\mathrm{Lr} 442$ & 1-Jul-01 & - & - & $\mathrm{A}$ \\
\hline Asian & Kuril Islands & Raikoke Island & P608 & 2-Jul-01 & - & - & $\mathrm{A}$ \\
\hline Asian & Kuril Islands & Raikoke Island & P623 & 2-Jul-01 & - & - & $\mathrm{A}$ \\
\hline Asian & Kuril Islands & Raikoke Island & P627 & 2-Jul-01 & - & - & $\mathrm{A}$ \\
\hline Asian & Kuril Islands & Raikoke Island & P629 & 2-Jul-01 & - & - & $\mathrm{A}$ \\
\hline Asian & Kuril Islands & Srednego Island & $\mathrm{C} 503$ & 4-Jul-01 & - & - & $\mathrm{A}$ \\
\hline Asian & Sea of Okhotsk & Iony Island & $\mathrm{N} 258$ & 16-Jul-01 & - & - & $\mathrm{A}$ \\
\hline Asian & Sea of Okhotsk & Iony Island & $\mathrm{N} 260$ & 16-Jul-01 & - & - & $\mathrm{A}$ \\
\hline Asian & Sea of Okhotsk & Iony Island & N406 & 29-Jun-02 & 27.0 & $\mathrm{M}$ & $\mathrm{A}$ \\
\hline Asian & Sea of Okhotsk & Iony Island & $\mathrm{N} 408$ & 29-Jun-02 & 17.5 & $\mathrm{M}$ & $\mathrm{A}$ \\
\hline Asian & Sea of Okhotsk & Iony Island & $\mathrm{N} 436$ & 29-Jun-02 & 23.0 & $\mathrm{M}$ & A \\
\hline Asian & Sea of Okhotsk & Iony Island & N438 & 29-Jun-02 & 15.5 & $\mathrm{~F}$ & $\mathrm{~A}$ \\
\hline Asian & Sea of Okhotsk & Yamsky Island & $\mathrm{R} 245$ & 7-Mar-02 & 31.0 & $\mathrm{~F}$ & $\mathrm{~A}$ \\
\hline Asian & Sea of Okhotsk & Yamsky Island & R269 & 7-Mar-02 & 20.5 & $\mathrm{M}$ & $\mathrm{A}$ \\
\hline Asian & Sea of Okhotsk & Yamsky Island & R290 & 7-Mar-02 & 30.0 & $\mathrm{M}$ & $\mathrm{A}$ \\
\hline Central & Commander Islands & Medney Island & M423 & 2-Jul-02 & 23.0 & $\mathrm{~F}$ & $\mathrm{~A}$ \\
\hline Central & Commander Islands & Medney Island & M446 & 2-Jul-02 & 33.0 & $\mathrm{~F}$ & A \\
\hline Central & Commander Islands & Medney Island & M469 & 2-Jul-02 & 33.5 & $\mathrm{M}$ & $\mathrm{A}$ \\
\hline Central & Commander Islands & Medney Island & M473 & 2-Jul-02 & 41.5 & $\mathrm{M}$ & $\mathrm{A}$ \\
\hline Asian & Kamchatka & Kozlov C. & $\mathrm{K} 226$ & 5-Jul-02 & 29.5 & $\mathrm{~F}$ & AAA \\
\hline Asian & Kuril Islands & Antsiferov Island & Y468 & 26-Jun-01 & - & - & AAA \\
\hline Asian & Kuril Islands & Chernyye Brat'ya & Br603 & 7-Jul-01 & - & - & AAA \\
\hline Asian & Kuril Islands & Chernyye Brat'ya & Br623 & 7-Jul-01 & - & - & AAA \\
\hline Asian & Kuril Islands & Lovushki Island & Lr406 & 1-Jul-01 & - & - & AAA \\
\hline Asian & Kuril Islands & Lovushki Island & Lr432 & 1-Jul-01 & - & - & AAA \\
\hline Asian & Kuril Islands & Lovushki Island & Lr444 & 1-Jul-01 & - & - & AAA \\
\hline Asian & Kuril Islands & Raikoke Island & P611 & 2-Jul-01 & - & - & AAA \\
\hline Asian & Kuril Islands & Raikoke Island & P620 & 2-Jul-01 & - & - & AAA \\
\hline Asian & Kuril Islands & Srednego Island & $\mathrm{C} 481$ & 4-Jul-01 & - & - & AAA \\
\hline Asian & Kuril Islands & Srednego Island & $\mathrm{C} 496$ & 4-Jul-01 & - & - & AAA \\
\hline Asian & Sea of Okhotsk & Iony Island & $\mathrm{N} 267$ & 16-Jul-01 & - & - & AAA \\
\hline Asian & Sea of Okhotsk & Iony Island & $\mathrm{N} 284$ & 16-Jul-01 & - & - & AAA \\
\hline Asian & Sea of Okhotsk & Yamsky Island & R234 & 7-Mar-02 & 29.0 & $\mathrm{~F}$ & AAA \\
\hline
\end{tabular}




\section{Appendix I Continued}

\begin{tabular}{|c|c|c|c|c|c|c|c|}
\hline Stock & Region & Rookery & Sample & Date Collected & Weight (kg) & Sex & Haplotype \\
\hline Asian & Sea of Okhotsk & Yamsky Island & R263 & 7-Mar-02 & 38.5 & $\mathrm{M}$ & AAA \\
\hline Central & Commander Islands & Medney Island & M435 & 2-Jul-02 & 31.0 & $\mathrm{~F}$ & AAA \\
\hline Central & Commander Islands & Medney Island & M437 & 2-Jul-02 & 37.5 & $\mathrm{M}$ & AAA \\
\hline Central & Commander Islands & Medney Island & M440 & 2-Jul-02 & 25.5 & $\mathrm{~F}$ & $\mathrm{AAA}$ \\
\hline Asian & Kuril Islands & Raikoke Island & P603 & 2-Jul-01 & - & - & AAAA \\
\hline Asian & Sea of Okhotsk & Iony Island & N262 & 16-Jul-01 & - & - & AAAA \\
\hline Asian & Sea of Okhotsk & Iony Island & $\mathrm{N} 275$ & 16-Jul-01 & - & - & AAAA \\
\hline Asian & Sea of Okhotsk & Iony Island & N276 & 16-Jul-01 & - & - & AAAA \\
\hline Asian & Sea of Okhotsk & Iony Island & N401 & 29-Jun-02 & 26.0 & $\mathrm{M}$ & AAAA \\
\hline Asian & Sea of Okhotsk & Iony Island & N412 & 29-Jun-02 & 29.5 & $\mathrm{M}$ & AAAA \\
\hline Asian & Sea of Okhotsk & Yamsky Island & R200 & 7-Mar-02 & 24.0 & $\mathrm{~F}$ & AAAA \\
\hline Asian & Sea of Okhotsk & Yamsky Island & R208 & 7-Mar-02 & 14.0 & $\mathrm{~F}$ & AAAA \\
\hline Asian & Sea of Okhotsk & Yamsky Island & $\mathrm{R} 211$ & 7-Mar-02 & 34.0 & $\mathrm{M}$ & AAAA \\
\hline Asian & Sea of Okhotsk & Yamsky Island & R286 & 7-Mar-02 & 24.0 & $\mathrm{~F}$ & AAAA \\
\hline Asian & Sea of Okhotsk & Yamsky Island & R288 & 7-Mar-02 & 39.0 & $\mathrm{M}$ & AAAA \\
\hline Asian & Sea of Okhotsk & Yamsky Island & R292 & 7-Mar-02 & 26.5 & $\mathrm{~F}$ & AAAA \\
\hline Asian & Kamchatka & Kozlov C. & K201 & 5-Jul-02 & 32.0 & $\mathrm{~F}$ & $\mathrm{BB}$ \\
\hline Asian & Kamchatka & Kozlov C. & K205 & 5-Jul-02 & 36.0 & $\mathrm{~F}$ & $\mathrm{BB}$ \\
\hline Asian & Kamchatka & Kozlov C. & K206 & 5-Jul-02 & 40.0 & $\mathrm{M}$ & $\mathrm{BB}$ \\
\hline Asian & Kamchatka & Kozlov C. & K207 & 5-Jul-02 & 28.5 & $\mathrm{~F}$ & $\mathrm{BB}$ \\
\hline Asian & Kamchatka & Kozlov C. & K211 & 5-Jul-02 & 38.0 & $\mathrm{M}$ & $\mathrm{BB}$ \\
\hline Asian & Kamchatka & Kozlov C. & K216 & 5-Jul-02 & 31.0 & $\mathrm{M}$ & $\mathrm{BB}$ \\
\hline Asian & Kamchatka & Kozlov C. & $\mathrm{K} 221$ & 5-Jul-02 & 30.5 & $\mathrm{~F}$ & $\mathrm{BB}$ \\
\hline Asian & Kamchatka & Kozlov C. & K222 & 5-Jul-02 & 28.5 & $\mathrm{~F}$ & $\mathrm{BB}$ \\
\hline Asian & Kamchatka & Kozlov C. & K225 & 5-Jul-02 & 28.5 & $\mathrm{M}$ & $\mathrm{BB}$ \\
\hline Asian & Kamchatka & Kozlov C. & K232 & 5-Jul-02 & 34.0 & $\mathrm{~F}$ & $\mathrm{BB}$ \\
\hline Asian & Kamchatka & Kozlov C. & $\mathrm{K} 235$ & 5-Jul-02 & 35.0 & $\mathrm{M}$ & $\mathrm{BB}$ \\
\hline Asian & Kamchatka & Kozlov C. & $\mathrm{K} 237$ & 5-Jul-02 & 23.5 & $\mathrm{~F}$ & $\mathrm{BB}$ \\
\hline Asian & Kamchatka & Kozlov C. & K242 & 5-Jul-02 & 30.0 & $\mathrm{M}$ & $\mathrm{BB}$ \\
\hline Asian & Kamchatka & Kozlov C. & K249 & 5-Jul-02 & 36.0 & $\mathrm{~F}$ & $\mathrm{BB}$ \\
\hline Asian & Kuril Islands & Antsiferov Island & Y457 & 26-Jun-01 & - & - & $\mathrm{BB}$ \\
\hline Asian & Kuril Islands & Antsiferov Island & Y472 & 26-Jun-01 & - & - & $\mathrm{BB}$ \\
\hline Asian & Kuril Islands & Antsiferov Island & Y486 & 26-Jun-01 & - & - & $\mathrm{BB}$ \\
\hline Asian & Kuril Islands & Antsiferov Island & Y489 & 26-Jun-01 & - & - & $\mathrm{BB}$ \\
\hline Asian & Kuril Islands & Antsiferov Island & Y492 & 26-Jun-01 & - & - & $\mathrm{BB}$ \\
\hline Asian & Kuril Islands & Chernyye Brat'ya & Br601 & 7-Jul-01 & - & - & $\mathrm{BB}$ \\
\hline Asian & Kuril Islands & Chernyye Brat'ya & Br607 & 7-Jul-01 & - & - & $\mathrm{BB}$ \\
\hline Asian & Kuril Islands & Chernyye Brat'ya & Br613 & 7-Jul-01 & - & - & $\mathrm{BB}$ \\
\hline Asian & Kuril Islands & Chernyye Brat'ya & Br618 & 7-Jul-01 & - & - & $\mathrm{BB}$ \\
\hline Asian & Kuril Islands & Chernyye Brat'ya & Br634 & 7-Jul-01 & - & - & $\mathrm{BB}$ \\
\hline Asian & Kuril Islands & Chernyye Brat'ya & Br637 & 7-Jul-01 & - & - & $\mathrm{BB}$ \\
\hline Asian & Kuril Islands & Lovushki Island & Lr404 & 1-Jul-01 & - & - & $\mathrm{BB}$ \\
\hline Asian & Kuril Islands & Lovushki Island & Lr412 & 1-Jul-01 & - & - & $\mathrm{BB}$ \\
\hline Asian & Kuril Islands & Lovushki Island & Lr435 & 1-Jul-01 & - & - & $\mathrm{BB}$ \\
\hline Asian & Kuril Islands & Raikoke Island & $\mathrm{P} 605$ & 2-Jul-01 & - & - & $\mathrm{BB}$ \\
\hline Asian & Kuril Islands & Raikoke Island & P606 & 2-Jul-01 & - & - & $\mathrm{BB}$ \\
\hline
\end{tabular}




\section{Appendix I Continued}

\begin{tabular}{|c|c|c|c|c|c|c|c|}
\hline Stock & Region & Rookery & Sample & Date Collected & Weight (kg) & Sex & Haplotype \\
\hline Asian & Kuril Islands & Raikoke Island & P622 & 2-Jul-01 & - & - & $\mathrm{BB}$ \\
\hline Asian & Kuril Islands & Raikoke Island & P625 & 2-Jul-01 & - & - & $\mathrm{BB}$ \\
\hline Asian & Kuril Islands & Srednego Island & $\mathrm{C} 492$ & 4-Jul-01 & - & - & $\mathrm{BB}$ \\
\hline Asian & Kuril Islands & Srednego Island & $\mathrm{C} 494$ & 4-Jul-01 & - & - & $\mathrm{BB}$ \\
\hline Asian & Kuril Islands & Srednego Island & C497 & 4-Jul-01 & - & - & $\mathrm{BB}$ \\
\hline Asian & Kuril Islands & Srednego Island & $\mathrm{C} 507$ & 4-Jul-01 & - & - & $\mathrm{BB}$ \\
\hline Asian & Sea of Okhotsk & Iony Island & $\mathrm{N} 253$ & 16-Jul-01 & - & - & $\mathrm{BB}$ \\
\hline Asian & Sea of Okhotsk & Iony Island & $\mathrm{N} 255$ & 16-Jul-01 & - & - & $\mathrm{BB}$ \\
\hline Asian & Sea of Okhotsk & Iony Island & N261 & 16-Jul-01 & - & - & $\mathrm{BB}$ \\
\hline Asian & Sea of Okhotsk & Iony Island & N266 & 16-Jul-01 & - & - & $\mathrm{BB}$ \\
\hline Asian & Sea of Okhotsk & Iony Island & N268 & 16-Jul-01 & - & - & $\mathrm{BB}$ \\
\hline Asian & Sea of Okhotsk & Iony Island & N269 & 16-Jul-01 & - & - & $\mathrm{BB}$ \\
\hline Asian & Sea of Okhotsk & Iony Island & $\mathrm{N} 271$ & 16-Jul-01 & - & - & $\mathrm{BB}$ \\
\hline Asian & Sea of Okhotsk & Iony Island & $\mathrm{N} 274$ & 16-Jul-01 & - & - & $\mathrm{BB}$ \\
\hline Asian & Sea of Okhotsk & Iony Island & $\mathrm{N} 278$ & 16-Jul-01 & - & - & $\mathrm{BB}$ \\
\hline Asian & Sea of Okhotsk & Iony Island & N279 & 16-Jul-01 & - & - & $\mathrm{BB}$ \\
\hline Asian & Sea of Okhotsk & Iony Island & $\mathrm{N} 280$ & 16-Jul-01 & - & - & $\mathrm{BB}$ \\
\hline Asian & Sea of Okhotsk & Iony Island & $\mathrm{N} 282$ & 16-Jul-01 & - & - & $\mathrm{BB}$ \\
\hline Asian & Sea of Okhotsk & Iony Island & N283 & 16-Jul-01 & - & - & $\mathrm{BB}$ \\
\hline Asian & Sea of Okhotsk & Iony Island & N403 & 29-Jun-02 & 30.0 & $\mathrm{M}$ & $\mathrm{BB}$ \\
\hline Asian & Sea of Okhotsk & Iony Island & N405 & 29-Jun-02 & 22.0 & $\mathrm{M}$ & $\mathrm{BB}$ \\
\hline Asian & Sea of Okhotsk & Iony Island & N407 & 29-Jun-02 & 23.5 & $\mathrm{~F}$ & $\mathrm{BB}$ \\
\hline Asian & Sea of Okhotsk & Iony Island & N413 & 29-Jun-02 & 26.5 & $\mathrm{M}$ & $\mathrm{BB}$ \\
\hline Asian & Sea of Okhotsk & Iony Island & N414 & 29-Jun-02 & 23.5 & $\mathrm{~F}$ & $\mathrm{BB}$ \\
\hline Asian & Sea of Okhotsk & Iony Island & N415 & 29-Jun-02 & 25.5 & $\mathrm{M}$ & $\mathrm{BB}$ \\
\hline Asian & Sea of Okhotsk & Iony Island & N418 & 29-Jun-02 & 28.0 & $\mathrm{M}$ & $\mathrm{BB}$ \\
\hline Asian & Sea of Okhotsk & Iony Island & $\mathrm{N} 420$ & 29-Jun-02 & 26.0 & $\mathrm{M}$ & $\mathrm{BB}$ \\
\hline Asian & Sea of Okhotsk & Iony Island & N424 & 29-Jun-02 & 18.5 & $\mathrm{~F}$ & $\mathrm{BB}$ \\
\hline Asian & Sea of Okhotsk & Iony Island & N426 & 29-Jun-02 & 17.0 & $\mathrm{~F}$ & $\mathrm{BB}$ \\
\hline Asian & Sea of Okhotsk & Iony Island & $\mathrm{N} 428$ & 29-Jun-02 & 21.0 & $\mathrm{~F}$ & $\mathrm{BB}$ \\
\hline Asian & Sea of Okhotsk & Iony Island & N429 & 29-Jun-02 & 22.5 & $\mathrm{~F}$ & $\mathrm{BB}$ \\
\hline Asian & Sea of Okhotsk & Iony Island & N431 & 29-Jun-02 & 25.0 & $\mathrm{M}$ & $\mathrm{BB}$ \\
\hline Asian & Sea of Okhotsk & Iony Island & N433 & 29-Jun-02 & 21.5 & $\mathrm{~F}$ & $\mathrm{BB}$ \\
\hline Asian & Sea of Okhotsk & Iony Island & $\mathrm{N} 434$ & 29-Jun-02 & 28.5 & $\mathrm{M}$ & $\mathrm{BB}$ \\
\hline Asian & Sea of Okhotsk & Iony Island & N439 & 29-Jun-02 & 19.0 & $\mathrm{~F}$ & $\mathrm{BB}$ \\
\hline Asian & Sea of Okhotsk & Iony Island & N440 & 29-Jun-02 & 17.5 & $\mathrm{~F}$ & $\mathrm{BB}$ \\
\hline Asian & Sea of Okhotsk & Iony Island & N441 & 29-Jun-02 & 24.5 & $\mathrm{M}$ & $\mathrm{BB}$ \\
\hline Asian & Sea of Okhotsk & Iony Island & N442 & 29-Jun-02 & 26.5 & $\mathrm{M}$ & $\mathrm{BB}$ \\
\hline Asian & Sea of Okhotsk & Iony Island & $\mathrm{N} 444$ & 29-Jun-02 & 29.0 & $\mathrm{M}$ & $\mathrm{BB}$ \\
\hline Asian & Sea of Okhotsk & Iony Island & N445 & 29-Jun-02 & 16.0 & $\mathrm{~F}$ & $\mathrm{BB}$ \\
\hline Asian & Sea of Okhotsk & Iony Island & N449 & 29-Jun-02 & 21.0 & $\mathrm{M}$ & $\mathrm{BB}$ \\
\hline Asian & Sea of Okhotsk & Iony Island & N451 & 29-Jun-02 & 29.5 & $\mathrm{M}$ & $\mathrm{BB}$ \\
\hline Asian & Sea of Okhotsk & Yamsky Island & R203 & 7-Mar-02 & 22.5 & $\mathrm{~F}$ & $\mathrm{BB}$ \\
\hline Asian & Sea of Okhotsk & Yamsky Island & R228 & 7-Mar-02 & 23.5 & $\mathrm{M}$ & $\mathrm{BB}$ \\
\hline Asian & Sea of Okhotsk & Yamsky Island & $\mathrm{R} 230$ & 7-Mar-02 & 38.0 & $\mathrm{M}$ & $\mathrm{BB}$ \\
\hline Asian & Sea of Okhotsk & Yamsky Island & $\mathrm{R} 235$ & 7-Mar-02 & 24.5 & $\mathrm{~F}$ & $\mathrm{BB}$ \\
\hline
\end{tabular}




\section{Appendix I Continued}

\begin{tabular}{|c|c|c|c|c|c|c|c|}
\hline Stock & Region & Rookery & Sample & Date Collected & Weight (kg) & Sex & Haplotype \\
\hline Asian & Sea of Okhotsk & Yamsky Island & $\mathrm{R} 250$ & 7-Mar-02 & 29.5 & $\mathrm{M}$ & $\mathrm{BB}$ \\
\hline Asian & Sea of Okhotsk & Yamsky Island & R252 & 7-Mar-02 & 29.0 & $\mathrm{M}$ & $\mathrm{BB}$ \\
\hline Asian & Sea of Okhotsk & Yamsky Island & R255 & 7-Mar-02 & 24.0 & $\mathrm{~F}$ & $\mathrm{BB}$ \\
\hline Asian & Sea of Okhotsk & Yamsky Island & R261 & 7-Mar-02 & 33.0 & $\mathrm{M}$ & $\mathrm{BB}$ \\
\hline Asian & Sea of Okhotsk & Yamsky Island & R265 & 7-Mar-02 & 28.0 & $\mathrm{M}$ & $\mathrm{BB}$ \\
\hline Asian & Sea of Okhotsk & Yamsky Island & R274 & 7-Mar-02 & 30.0 & $\mathrm{~F}$ & $\mathrm{BB}$ \\
\hline Asian & Sea of Okhotsk & Yamsky Island & R276 & 7-Mar-02 & 36.5 & $\mathrm{M}$ & $\mathrm{BB}$ \\
\hline Asian & Sea of Okhotsk & Yamsky Island & R294 & 7-Mar-02 & 23.5 & $\mathrm{M}$ & $\mathrm{BB}$ \\
\hline Asian & Sea of Okhotsk & Yamsky Island & R297 & 7-Mar-02 & 38.5 & $\mathrm{M}$ & $\mathrm{BB}$ \\
\hline Asian & Sea of Okhotsk & Yamsky Island & R300 & 7-Mar-02 & 17.5 & $\bar{M}$ & $\mathrm{BB}$ \\
\hline Central & Commander Islands & Medney Island & M408 & 2-Jul-02 & 31.0 & $\mathrm{~F}$ & $\mathrm{BB}$ \\
\hline Central & Commander Islands & Medney Island & M414 & 2-Jul-02 & 39.0 & $\mathrm{M}$ & $\mathrm{BB}$ \\
\hline Central & Commander Islands & Medney Island & M432 & 2-Jul-02 & 32.0 & $\mathrm{~F}$ & $\mathrm{BB}$ \\
\hline Central & Commander Islands & Medney Island & M434 & 2-Jul-02 & 32.5 & $\mathrm{M}$ & $\mathrm{BB}$ \\
\hline Central & Commander Islands & Medney Island & M443 & 2-Jul-02 & 28.5 & $\mathrm{~F}$ & $\mathrm{BB}$ \\
\hline Central & Commander Islands & Medney Island & M463 & 2-Jul-02 & 32.5 & $\mathrm{~F}$ & $\mathrm{BB}$ \\
\hline Central & Commander Islands & Medney Island & M466 & 2-Jul-02 & 36.0 & $\mathrm{M}$ & $\mathrm{BB}$ \\
\hline Asian & Kamchatka & Kozlov C. & K200 & 5-Jul-02 & 29.5 & $\mathrm{M}$ & $\mathrm{CC}$ \\
\hline Asian & Kamchatka & Kozlov C. & $\mathrm{K} 210$ & 5-Jul-02 & 40.0 & $\mathrm{M}$ & $\mathrm{CC}$ \\
\hline Asian & Kamchatka & Kozlov C. & $\mathrm{K} 227$ & 5-Jul-02 & 36.5 & $\mathrm{M}$ & $\mathrm{CC}$ \\
\hline Asian & Kamchatka & Kozlov C. & K231 & 5-Jul-02 & 30.5 & $\mathrm{~F}$ & $\mathrm{CC}$ \\
\hline Asian & Kamchatka & Kozlov C. & K238 & 5-Jul-02 & 40.0 & $\mathrm{M}$ & $\mathrm{CC}$ \\
\hline Asian & Kamchatka & Kozlov C. & $\mathrm{K} 246$ & 5-Jul-02 & 40.0 & $\mathrm{M}$ & $\mathrm{CC}$ \\
\hline Asian & Kamchatka & Kozlov C. & $\mathrm{K} 247$ & 5-Jul-02 & 34.0 & $\mathrm{M}$ & $\mathrm{CC}$ \\
\hline Asian & Kuril Islands & Antsiferov Island & Y453 & 26-Jun-01 & - & - & $\mathrm{CC}$ \\
\hline Central & Commander Islands & Medney Island & M403 & 2-Jul-02 & 32.5 & $\mathrm{M}$ & $\mathrm{CC}$ \\
\hline Central & Commander Islands & Medney Island & M406 & 2-Jul-02 & 26.5 & $\mathrm{~F}$ & $\mathrm{CC}$ \\
\hline Central & Commander Islands & Medney Island & M410 & 2-Jul-02 & 37.5 & $\mathrm{M}$ & $\mathrm{CC}$ \\
\hline Central & Commander Islands & Medney Island & M416 & 2-Jul-02 & 29.0 & $\mathrm{~F}$ & $\mathrm{CC}$ \\
\hline Central & Commander Islands & Medney Island & M417 & 2-Jul-02 & 39.0 & $\mathrm{M}$ & $\mathrm{CC}$ \\
\hline Central & Commander Islands & Medney Island & M418 & 2-Jul-02 & 22.5 & $\mathrm{~F}$ & $\mathrm{CC}$ \\
\hline Central & Commander Islands & Medney Island & M427 & 2-Jul-02 & 24.0 & $\mathrm{M}$ & $\mathrm{CC}$ \\
\hline Central & Commander Islands & Medney Island & M431 & 2-Jul-02 & 32.5 & $\mathrm{M}$ & $\mathrm{CC}$ \\
\hline Central & Commander Islands & Medney Island & M433 & 2-Jul-02 & 36.0 & $\mathrm{M}$ & $\mathrm{CC}$ \\
\hline Central & Commander Islands & Medney Island & M441 & 2-Jul-02 & 32.5 & $\mathrm{~F}$ & $\mathrm{CC}$ \\
\hline Central & Commander Islands & Medney Island & M447 & 2-Jul-02 & 31.5 & $\mathrm{~F}$ & $\mathrm{CC}$ \\
\hline Central & Commander Islands & Medney Island & M455 & 2-Jul-02 & 35.5 & $\mathrm{M}$ & $\mathrm{CC}$ \\
\hline Central & Commander Islands & Medney Island & M458 & 2-Jul-02 & 34.0 & $\mathrm{~F}$ & $\mathrm{CC}$ \\
\hline Central & Commander Islands & Medney Island & M462 & 2-Jul-02 & 28.0 & $\mathrm{~F}$ & $\mathrm{CC}$ \\
\hline Central & Commander Islands & Medney Island & M465 & 2-Jul-02 & 32.0 & $\mathrm{~F}$ & $\mathrm{CC}$ \\
\hline Central & Commander Islands & Medney Island & M467 & 2-Jul-02 & 33.5 & $\mathrm{~F}$ & $\mathrm{CC}$ \\
\hline Central & Commander Islands & Medney Island & M471 & 2-Jul-02 & 31.0 & $\mathrm{~F}$ & $\mathrm{CC}$ \\
\hline Central & Commander Islands & Medney Island & M477 & 2-Jul-02 & 35.0 & $\mathrm{~F}$ & $\mathrm{CC}$ \\
\hline Central & Commander Islands & Medney Island & M444 & 2-Jul-02 & 26.0 & $\mathrm{~F}$ & $\mathrm{DD}$ \\
\hline Central & Commander Islands & Medney Island & M448 & 2-Jul-02 & 36.0 & $\mathrm{~F}$ & DD \\
\hline Central & Commander Islands & Medney Island & M472 & 2-Jul-02 & 33.0 & $\mathrm{~F}$ & DD \\
\hline
\end{tabular}




\section{Appendix I Continued}

\begin{tabular}{|c|c|c|c|c|c|c|c|}
\hline Stock & Region & Rookery & Sample & Date Collected & Weight (kg) & Sex & Haplotype \\
\hline Central & Commander Islands & Medney Island & M401 & 2-Jul-02 & 28.0 & $\mathrm{~F}$ & DDD \\
\hline Central & Commander Islands & Medney Island & M404 & 2-Jul-02 & 36.0 & $M$ & DDD \\
\hline Central & Commander Islands & Medney Island & M411 & 2-Jul-02 & 34.0 & $\mathrm{M}$ & DDD \\
\hline Central & Commander Islands & Medney Island & M454 & 2-Jul-02 & 21.5 & $\mathrm{~F}$ & $\mathrm{E}$ \\
\hline Asian & Kuril Islands & Lovushki Island & Lr423 & 1-Jul-01 & - & - & $\mathrm{EE}$ \\
\hline Asian & Kamchatka & Kozlov C. & K229 & 5-Jul-02 & 30.0 & $\mathrm{~F}$ & EEE \\
\hline Asian & Kamchatka & Kozlov C. & K215 & 5-Jul-02 & 39.5 & $M$ & EEEE \\
\hline Asian & Kuril Islands & Antsiferov Island & Y487 & 26-Jun-01 & - & - & EEEE \\
\hline Asian & Kuril Islands & Raikoke Island & P601 & 2-Jul-01 & - & - & EEEE \\
\hline Asian & Kamchatka & Kozlov C. & K220 & 5-Jul-02 & 34.5 & $\mathrm{M}$ & $\mathrm{FF}$ \\
\hline Asian & Kuril Islands & Chernyye Brat'ya & Br627 & 7-Jul-01 & - & - & $\mathrm{FF}$ \\
\hline Asian & Kuril Islands & Lovushki Island & Lr427 & 1-Jul-01 & - & - & FF \\
\hline Asian & Kuril Islands & Srednego Island & $\mathrm{C} 484$ & 4-Jul-01 & - & - & $\mathrm{FF}$ \\
\hline Asian & Kuril Islands & Srednego Island & $\mathrm{C} 486$ & 4-Jul-01 & - & - & $\mathrm{FF}$ \\
\hline Asian & Kuril Islands & Srednego Island & $\mathrm{C} 488$ & 4-Jul-01 & - & - & FF \\
\hline Asian & Kuril Islands & Srednego Island & C499 & 4-Jul-01 & - & - & $\mathrm{FF}$ \\
\hline Asian & Sea of Okhotsk & Iony Island & $\mathrm{N} 251$ & 16-Jul-01 & - & - & $\mathrm{FF}$ \\
\hline Asian & Sea of Okhotsk & Iony Island & $\mathrm{N} 256$ & 16-Jul-01 & - & - & FF \\
\hline Asian & Sea of Okhotsk & Iony Island & N411 & 29-Jun-02 & 21.5 & $\mathrm{M}$ & $\mathrm{FF}$ \\
\hline Asian & Sea of Okhotsk & Iony Island & $\mathrm{N} 421$ & 29-Jun-02 & 20.0 & $\mathrm{M}$ & $\mathrm{FF}$ \\
\hline Asian & Sea of Okhotsk & Iony Island & N427 & 29-Jun-02 & 25.0 & $\mathrm{M}$ & $\mathrm{FF}$ \\
\hline Asian & Sea of Okhotsk & Iony Island & N430 & 29-Jun-02 & 21.5 & $\mathrm{M}$ & FF \\
\hline Asian & Sea of Okhotsk & Iony Island & N446 & 29-Jun-02 & 17.0 & $\mathrm{M}$ & $\mathrm{FF}$ \\
\hline Asian & Sea of Okhotsk & Iony Island & N447 & 29-Jun-02 & 25.0 & $\mathrm{M}$ & $\mathrm{FF}$ \\
\hline Asian & Sea of Okhotsk & Yamsky Island & $\mathrm{R} 214$ & 7-Mar-02 & 29.0 & $\mathrm{M}$ & FF \\
\hline Asian & Sea of Okhotsk & Yamsky Island & $\mathrm{R} 226$ & 7-Mar-02 & 35.0 & $\mathrm{M}$ & $\mathrm{FF}$ \\
\hline Asian & Sea of Okhotsk & Yamsky Island & R237 & 7-Mar-02 & 27.5 & $\mathrm{~F}$ & FF \\
\hline Asian & Sea of Okhotsk & Yamsky Island & R272 & 7-Mar-02 & 26.0 & $\mathrm{M}$ & FF \\
\hline Asian & Sea of Okhotsk & Yamsky Island & $\mathrm{R} 280$ & 7-Mar-02 & 34.0 & $\mathrm{M}$ & $\mathrm{FF}$ \\
\hline Asian & Sea of Okhotsk & Yamsky Island & $\mathrm{R} 282$ & 7-Mar-02 & 25.5 & $\mathrm{M}$ & $\mathrm{FF}$ \\
\hline Asian & Sea of Okhotsk & Yamsky Island & R295 & 7-Mar-02 & 36.0 & $\mathrm{~F}$ & FF \\
\hline Central & Commander Islands & Medney Island & M409 & 2-Jul-02 & 35.0 & $\mathrm{M}$ & $\mathrm{FF}$ \\
\hline Asian & Kamchatka & Kozlov C. & K243 & 5-Jul-02 & 31.0 & $\mathrm{M}$ & FFFF \\
\hline Asian & Kuril Islands & Antsiferov Island & Y475 & 26-Jun-01 & - & - & FFFF \\
\hline Asian & Kuril Islands & Chernyye Brat'ya & Br632 & 7-Jul-01 & - & - & FFFF \\
\hline Asian & Kuril Islands & Lovushki Island & Lr434 & 1-Jul-01 & - & - & FFFF \\
\hline Asian & Kuril Islands & Lovushki Island & Lr440 & 1-Jul-01 & - & - & FFFF \\
\hline Asian & Kuril Islands & Raikoke Island & P610 & 2-Jul-01 & - & - & FFFF \\
\hline Asian & Sea of Okhotsk & Iony Island & $\mathrm{N} 252$ & 16-Jul-01 & - & - & FFFF \\
\hline Asian & Sea of Okhotsk & Iony Island & N425 & 29-Jun-02 & 23.0 & $\mathrm{M}$ & FFFF \\
\hline Asian & Sea of Okhotsk & Yamsky Island & R217 & 7-Mar-02 & 20.5 & $\mathrm{~F}$ & FFFF \\
\hline Asian & Sea of Okhotsk & Yamsky Island & $\mathrm{R} 281$ & 7-Mar-02 & 25.5 & $\mathrm{M}$ & FFFF \\
\hline Asian & Kuril Islands & Antsiferov Island & Y479 & 26-Jun-01 & - & - & $\mathrm{G}$ \\
\hline Asian & Kuril Islands & Antsiferov Island & Y481 & 26-Jun-01 & - & - & $\mathrm{G}$ \\
\hline Central & Commander Islands & Medney Island & M468 & 2-Jul-02 & 30.0 & $\mathrm{M}$ & $\mathrm{G}$ \\
\hline Asian & Kamchatka & Kozlov C. & K224 & 5-Jul-02 & 35.5 & $\mathrm{M}$ & GGGGGG \\
\hline
\end{tabular}




\section{Appendix I Continued}

\begin{tabular}{|c|c|c|c|c|c|c|c|}
\hline Stock & Region & Rookery & Sample & Date Collected & Weight (kg) & Sex & Haplotype \\
\hline Central & Commander Islands & Medney Island & M402 & 2-Jul-02 & 37.0 & $\mathrm{M}$ & $\mathrm{HH}$ \\
\hline Central & Commander Islands & Medney Island & M412 & 2-Jul-02 & 30.0 & $\mathrm{M}$ & $\mathrm{HH}$ \\
\hline Central & Commander Islands & Medney Island & M420 & 2-Jul-02 & 33.0 & $\mathrm{M}$ & $\mathrm{HH}$ \\
\hline Central & Commander Islands & Medney Island & M429 & 2-Jul-02 & 33.5 & $\mathrm{M}$ & $\mathrm{HH}$ \\
\hline Central & Commander Islands & Medney Island & M450 & 2-Jul-02 & 26.5 & $\mathrm{~F}$ & $\mathrm{HH}$ \\
\hline Central & Commander Islands & Medney Island & M452 & 2-Jul-02 & 32.0 & $\mathrm{~F}$ & $\mathrm{HH}$ \\
\hline Central & Commander Islands & Medney Island & M460 & 2-Jul-02 & 25.0 & $\mathrm{~F}$ & $\mathrm{HH}$ \\
\hline Central & Commander Islands & Medney Island & M464 & 2-Jul-02 & 43.0 & $\mathrm{M}$ & $\mathrm{HH}$ \\
\hline Central & Commander Islands & Medney Island & M479 & 2-Jul-02 & 42.0 & $\mathrm{M}$ & $\mathrm{HH}$ \\
\hline Asian & Kamchatka & Kozlov C. & K204 & 5-Jul-02 & 33.5 & $\mathrm{M}$ & HНHНHН \\
\hline Asian & Kamchatka & Kozlov C. & K241 & 5-Jul-02 & 42.5 & $\mathrm{M}$ & НHНHНH \\
\hline Asian & Kuril Islands & Chernyye Brat'ya & Br625 & 7-Jul-01 & - & - & III \\
\hline Asian & Sea of Okhotsk & Iony Island & $\mathrm{N} 402$ & 29-Jun-02 & 23.0 & $\mathrm{~F}$ & IIIIII \\
\hline Central & Commander Islands & Medney Island & M424 & 2-Jul-02 & 27.5 & $\mathrm{~F}$ & JJJ \\
\hline Central & Commander Islands & Medney Island & M470 & 2-Jul-02 & 43.5 & $\mathrm{M}$ & JJJ \\
\hline Asian & Sea of Okhotsk & Iony Island & N423 & 29-Jun-02 & 31.5 & $\mathrm{M}$ & JJJJJJ \\
\hline Asian & Kamchatka & Kozlov C. & K228 & 5-Jul-02 & 25.5 & $\mathrm{~F}$ & KKK \\
\hline Asian & Kamchatka & Kozlov C. & K234 & 5-Jul-02 & 34.0 & $\mathrm{M}$ & KKK \\
\hline Asian & Kamchatka & Kozlov C. & K244 & 5-Jul-02 & 30.5 & $\mathrm{M}$ & KKK \\
\hline Asian & Sea of Okhotsk & Yamsky Island & $\mathrm{R} 232$ & 7-Mar-02 & 26.5 & $\mathrm{~F}$ & KKK \\
\hline Asian & Sea of Okhotsk & Yamsky Island & R242 & 7-Mar-02 & 32.0 & $\mathrm{M}$ & KKK \\
\hline Asian & Sea of Okhotsk & Yamsky Island & R254 & 7-Mar-02 & 23.5 & $\mathrm{~F}$ & KKK \\
\hline Central & Commander Islands & Medney Island & M483 & 2-Jul-02 & 31.5 & $\mathrm{~F}$ & KKK \\
\hline Asian & Kamchatka & Kozlov C. & $\mathrm{K} 245$ & 5-Jul-02 & 27.5 & $\mathrm{~F}$ & LLL \\
\hline Asian & Kamchatka & Kozlov C. & K248 & 5-Jul-02 & 39.0 & $\mathrm{~F}$ & LLL \\
\hline Asian & Kuril Islands & Antsiferov Island & Y477 & 26-Jun-01 & - & - & LLL \\
\hline Asian & Kuril Islands & Chernyye Brat'ya & Br604 & 7-Jul-01 & - & - & LLL \\
\hline Asian & Kuril Islands & Chernyye Brat'ya & Br616 & 7-Jul-01 & - & - & LLL \\
\hline Asian & Kuril Islands & Chernyye Brat'ya & Br630 & 7-Jul-01 & - & - & LLL \\
\hline Asian & Kuril Islands & Raikoke Island & P607 & 2-Jul-01 & - & - & LLL \\
\hline Asian & Kuril Islands & Srednego Island & C491 & 4-Jul-01 & - & - & LLL \\
\hline Asian & Kuril Islands & Srednego Island & $\mathrm{C} 500$ & 4-Jul-01 & - & - & LLL \\
\hline Asian & Kuril Islands & Srednego Island & C504 & 4-Jul-01 & - & - & $\overline{L L L}$ \\
\hline Asian & Sea of Okhotsk & Iony Island & N443 & 29-Jun-02 & 30.5 & $\mathrm{M}$ & LLL \\
\hline Asian & Sea of Okhotsk & Yamsky Island & R206 & 7-Mar-02 & 27.5 & $\mathrm{M}$ & LLL \\
\hline Asian & Sea of Okhotsk & Yamsky Island & $\mathrm{R} 222$ & 7-Mar-02 & 32.0 & $\mathrm{M}$ & LLL \\
\hline Asian & Sea of Okhotsk & Yamsky Island & R224 & 7-Mar-02 & 32.5 & $\mathrm{M}$ & LLL \\
\hline Asian & Sea of Okhotsk & Yamsky Island & R299 & 7-Mar-02 & 28.0 & $\mathrm{M}$ & LLL \\
\hline Asian & Kamchatka & Kozlov C. & K202 & 5-Jul-02 & 22.5 & $\mathrm{M}$ & MMM \\
\hline Asian & Sea of Okhotsk & Iony Island & $\mathrm{N} 254$ & 16-Jul-01 & - & - & MMM \\
\hline Asian & Sea of Okhotsk & Iony Island & N264 & 16-Jul-01 & - & - & MMM \\
\hline Asian & Sea of Okhotsk & Iony Island & $\mathrm{N} 273$ & 16-Jul-01 & - & - & MMM \\
\hline Asian & Sea of Okhotsk & Iony Island & N417 & 29-Jun-02 & 27.0 & $\mathrm{~F}$ & MMM \\
\hline Asian & Sea of Okhotsk & Iony Island & N437 & 29-Jun-02 & 23.0 & $\mathrm{M}$ & MMM \\
\hline Asian & Sea of Okhotsk & Iony Island & N448 & 29-Jun-02 & 24.0 & $\mathrm{M}$ & MMM \\
\hline Asian & Sea of Okhotsk & Yamsky Island & R249 & 7-Mar-02 & 37.0 & $\mathrm{M}$ & MMM \\
\hline
\end{tabular}




\section{Appendix I Continued}

\begin{tabular}{|c|c|c|c|c|c|c|c|}
\hline Stock & Region & Rookery & Sample & Date Collected & Weight (kg) & Sex & Haplotype \\
\hline Asian & Kuril Islands & Lovushki Island & Lr417 & 1-Jul-01 & - & - & QQQQ \\
\hline Asian & Kuril Islands & Chernyye Brat'ya & Br639 & 7-Jul-01 & - & - & $\mathrm{RR}$ \\
\hline Asian & Kamchatka & Kozlov C. & $\mathrm{K} 214$ & 5-Jul-02 & 31.5 & $\mathrm{~F}$ & $\mathrm{~S}$ \\
\hline Asian & Kamchatka & Kozlov C. & K239 & 5-Jul-02 & 35.0 & $\mathrm{~F}$ & $\mathrm{~S}$ \\
\hline Asian & Kamchatka & Kozlov C. & $\mathrm{K} 240$ & 5-Jul-02 & 31.0 & $\mathrm{M}$ & $\mathrm{S}$ \\
\hline Asian & Kuril Islands & Antsiferov Island & Y462 & 26-Jun-01 & - & - & $\mathrm{S}$ \\
\hline Asian & Kuril Islands & Antsiferov Island & Y470 & 26-Jun-01 & - & - & $\mathrm{S}$ \\
\hline Asian & Kuril Islands & Antsiferov Island & Y491 & 26-Jun-01 & - & - & $\mathrm{S}$ \\
\hline Asian & Kuril Islands & Lovushki Island & Lr402 & 1-Jul-01 & - & - & $\mathrm{S}$ \\
\hline Asian & Kuril Islands & Lovushki Island & Lr409 & 1-Jul-01 & - & - & $\mathrm{S}$ \\
\hline Asian & Kuril Islands & Raikoke Island & P615 & 2-Jul-01 & - & - & $\mathrm{S}$ \\
\hline Asian & Kuril Islands & Raikoke Island & P621 & 2-Jul-01 & - & - & $\mathrm{S}$ \\
\hline Asian & Sea of Okhotsk & Iony Island & N277 & 16-Jul-01 & - & - & $\mathrm{S}$ \\
\hline Central & Commander Islands & Medney Island & M400 & 2-Jul-02 & 31.5 & $\mathrm{~F}$ & $\mathrm{~S}$ \\
\hline Central & Commander Islands & Medney Island & M407 & 2-Jul-02 & 27.5 & $\mathrm{M}$ & $\mathrm{S}$ \\
\hline Central & Commander Islands & Medney Island & M413 & 2-Jul-02 & 21.0 & $\mathrm{~F}$ & $\mathrm{~S}$ \\
\hline Central & Commander Islands & Medney Island & M415 & 2-Jul-02 & 29.0 & $\mathrm{~F}$ & $\mathrm{~S}$ \\
\hline Central & Commander Islands & Medney Island & M421 & 2-Jul-02 & 22.5 & $\mathrm{~F}$ & $\mathrm{~S}$ \\
\hline Central & Commander Islands & Medney Island & M436 & 2-Jul-02 & 26.5 & $\mathrm{~F}$ & $\mathrm{~S}$ \\
\hline Central & Commander Islands & Medney Island & M438 & 2-Jul-02 & 36.5 & $\mathrm{~F}$ & $\mathrm{~S}$ \\
\hline Central & Commander Islands & Medney Island & M445 & 2-Jul-02 & 36.5 & $\mathrm{M}$ & $\mathrm{S}$ \\
\hline Central & Commander Islands & Medney Island & M449 & 2-Jul-02 & 40.5 & $\mathrm{M}$ & $\mathrm{S}$ \\
\hline Central & Commander Islands & Medney Island & M453 & 2-Jul-02 & 24.0 & $\mathrm{~F}$ & $\mathrm{~S}$ \\
\hline Central & Commander Islands & Medney Island & M457 & 2-Jul-02 & 42.0 & $\mathrm{M}$ & $\mathrm{S}$ \\
\hline Central & Commander Islands & Medney Island & M459 & 2-Jul-02 & 40.0 & $\mathrm{M}$ & $\mathrm{S}$ \\
\hline Central & Commander Islands & Medney Island & M461 & 2-Jul-02 & 35.0 & $\mathrm{M}$ & $\mathrm{S}$ \\
\hline Central & Commander Islands & Medney Island & M475 & 2-Jul-02 & 40.5 & $\mathrm{M}$ & $\mathrm{S}$ \\
\hline Central & Commander Islands & Medney Island & M476 & 2-Jul-02 & 31.5 & $\mathrm{~F}$ & $\mathrm{~S}$ \\
\hline Central & Commander Islands & Medney Island & M478 & 2-Jul-02 & 44.0 & $\mathrm{M}$ & $\mathrm{S}$ \\
\hline Central & Commander Islands & Medney Island & M480 & 2-Jul-02 & 25.0 & $\mathrm{~F}$ & $\mathrm{~S}$ \\
\hline Central & Commander Islands & Medney Island & M482 & 2-Jul-02 & 31.5 & $\mathrm{~F}$ & $\mathrm{~S}$ \\
\hline Central & Commander Islands & Medney Island & M484 & 5-Jul-02 & 39.5 & $\mathrm{M}$ & $\mathrm{S}$ \\
\hline Asian & Kuril Islands & Chernyye Brat'ya & Br621 & 7-Jul-01 & - & - & SSSSS \\
\hline Asian & Kuril Islands & Chernyye Brat'ya & Br633 & 7-Jul-01 & - & - & SSSSS \\
\hline Asian & Sea of Okhotsk & Iony Island & N416 & 29-Jun-02 & 24.0 & $\mathrm{~F}$ & SSSSS \\
\hline Asian & Sea of Okhotsk & Iony Island & $\mathrm{N} 432$ & 29-Jun-02 & 32.0 & $\mathrm{M}$ & SSSSS \\
\hline Central & Commander Islands & Medney Island & M442 & 2-Jul-02 & 35.5 & $\mathrm{M}$ & $\mathrm{T}$ \\
\hline Asian & Kuril Islands & Raikoke Island & P618 & 2-Jul-01 & - & - & TTT \\
\hline Asian & Kuril Islands & Srednego Island & $\mathrm{C} 482$ & 4-Jul-01 & - & - & TTTTT \\
\hline Asian & Kuril Islands & Raikoke Island & P614 & 2-Jul-01 & - & - & $\mathrm{U}$ \\
\hline Asian & Kuril Islands & Srednego Island & $\mathrm{C} 490$ & 4-Jul-01 & - & - & $\mathrm{U}$ \\
\hline Asian & Kuril Islands & Antsiferov Island & Y465 & 26-Jun-01 & - & - & UUU \\
\hline Asian & Kuril Islands & Srednego Island & C508 & 4-Jul-01 & - & - & UUU \\
\hline Asian & Sea of Okhotsk & Iony Island & N263 & 16-Jul-01 & - & - & UUU \\
\hline Asian & Sea of Okhotsk & Iony Island & $\mathrm{N} 272$ & 16-Jul-01 & - & - & UUU \\
\hline Asian & Sea of Okhotsk & Iony Island & N409 & 29-Jun-02 & 18.5 & $\mathrm{~F}$ & UUU \\
\hline
\end{tabular}




\section{Appendix I Continued}

\begin{tabular}{|c|c|c|c|c|c|c|c|}
\hline Stock & Region & Rookery & Sample & Date Collected & Weight (kg) & Sex & Haplotype \\
\hline Asian & Sea of Okhotsk & Iony Island & N410 & 29-Jun-02 & 21.0 & $\mathrm{~F}$ & UUU \\
\hline Asian & Sea of Okhotsk & Iony Island & N419 & 29-Jun-02 & 24.5 & $\mathrm{M}$ & UUU \\
\hline Asian & Sea of Okhotsk & Yamsky Island & R219 & 7-Mar-02 & 31.0 & $\mathrm{M}$ & UUU \\
\hline Asian & Sea of Okhotsk & Yamsky Island & R259 & 7-Mar-02 & 32.0 & $M$ & UUU \\
\hline Asian & Sea of Okhotsk & Yamsky Island & R284 & 7-Mar-02 & 23.0 & $\mathrm{~F}$ & UUU \\
\hline Asian & Sea of Okhotsk & Iony Island & $\mathrm{N} 250$ & 16-Jul-01 & - & - & UUUU \\
\hline Asian & Kuril Islands & Srednego Island & C489 & 4-Jul-01 & - & - & UUUUU \\
\hline Asian & Kuril Islands & Srednego Island & $\mathrm{C} 502$ & 4-Jul-01 & - & - & VVVVV \\
\hline Central & Commander Islands & Medney Island & M426 & 2-Jul-02 & 35.0 & $\bar{M}$ & $\mathrm{~W}$ \\
\hline Central & Commander Islands & Medney Island & M456 & 2-Jul-02 & 36.0 & $\mathrm{~F}$ & $\mathrm{~W}$ \\
\hline Asian & Kuril Islands & Lovushki Island & Lr439 & 1-Jul-01 & - & - & WWW \\
\hline Asian & Sea of Okhotsk & Iony Island & N422 & 29-Jun-02 & 26.5 & $F$ & WWW \\
\hline Asian & Kuril Islands & Raikoke Island & P612 & 2-Jul-01 & - & - & WWWWW \\
\hline Asian & Sea of Okhotsk & Iony Island & N404 & 29-Jun-02 & 26.0 & $\mathrm{M}$ & WWWWW \\
\hline Asian & Kamchatka & Kozlov C. & K217 & 5-Jul-02 & 33.5 & $\mathrm{M}$ & $\mathrm{X}$ \\
\hline Asian & Kuril Islands & Raikoke Island & P616 & 2-Jul-01 & - & - & XXXXX \\
\hline Asian & Kuril Islands & Antsiferov Island & Y452 & 26-Jun-01 & - & - & YYYYY \\
\hline Asian & Sea of Okhotsk & Iony Island & N435 & 29-Jun-02 & 28.5 & $\mathrm{M}$ & YYYYY \\
\hline Asian & Sea of Okhotsk & Yamsky Island & R239 & 7-Mar-02 & 30.0 & $\mathrm{~F}$ & YYYYY \\
\hline Asian & Sea of Okhotsk & Yamsky Island & R247 & 7-Mar-02 & 29.5 & $\mathrm{~F}$ & YYYYY \\
\hline Asian & Kamchatka & Kozlov C. & K208 & 5-Jul-02 & 24.5 & $\mathrm{~F}$ & $\mathrm{Z}$ \\
\hline Asian & Kamchatka & Kozlov C. & K209 & 5-Jul-02 & 35.0 & $\mathrm{M}$ & $Z$ \\
\hline Asian & Kamchatka & Kozlov C. & $\mathrm{K} 212$ & 5-Jul-02 & 37.5 & $\mathrm{M}$ & $\mathrm{Z}$ \\
\hline Asian & Kamchatka & Kozlov C. & K213 & 5-Jul-02 & 36.0 & $\mathrm{~F}$ & $Z$ \\
\hline Asian & Kamchatka & Kozlov C. & K230 & 5-Jul-02 & 36.5 & $M$ & $Z$ \\
\hline Asian & Kamchatka & Kozlov C. & K233 & 5-Jul-02 & 29.0 & $\mathrm{~F}$ & $Z$ \\
\hline Asian & Kuril Islands & Antsiferov Island & Y455 & 26-Jun-01 & - & - & $Z$ \\
\hline Central & Commander Islands & Medney Island & M419 & 2-Jul-02 & 28.0 & $F$ & $Z$ \\
\hline Central & Commander Islands & Medney Island & M422 & 2-Jul-02 & 27.0 & $\mathrm{~F}$ & $\mathrm{Z}$ \\
\hline Central & Commander Islands & Medney Island & M428 & 2-Jul-02 & 38.5 & $\mathrm{M}$ & $Z$ \\
\hline Central & Commander Islands & Medney Island & M430 & 2-Jul-02 & 30.5 & $\mathrm{~F}$ & $Z$ \\
\hline Central & Commander Islands & Medney Island & M451 & 2-Jul-02 & 38.5 & $M$ & $Z$ \\
\hline Central & Commander Islands & Medney Island & M474 & 2-Jul-02 & 37.0 & $\mathrm{M}$ & $\mathrm{Z}$ \\
\hline Central & Commander Islands & Medney Island & M481 & 2-Jul-02 & 31.5 & $\mathrm{~F}$ & $\mathrm{Z}$ \\
\hline Asian & Kamchatka & Kozlov C. & K218 & 5-Jul-02 & 36.0 & $\mathrm{M}$ & $\mathrm{ZZZ}$ \\
\hline Asian & Kamchatka & Kozlov C. & K223 & 5-Jul-02 & 32.5 & $\mathrm{M}$ & $\mathrm{ZZZ}$ \\
\hline Central & Commander Islands & Medney Island & M439 & 2-Jul-02 & 37.5 & $\mathrm{~F}$ & $\mathrm{ZZZ}$ \\
\hline Asian & Sea of Okhotsk & Yamsky Island & R216 & 7-Mar-02 & 27.5 & $\mathrm{~F}$ & ZZZZ \\
\hline Central & Commander Islands & Medney Island & M405 & 2-Jul-02 & 25.5 & $\mathrm{~F}$ & $\mathrm{ZZZZ}$ \\
\hline Asian & Kuril Islands & Antsiferov Island & Y460 & 26-Jun-01 & - & - & ZZZZZ \\
\hline
\end{tabular}




\section{Appendix II}

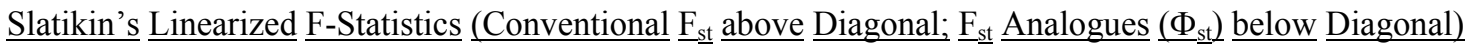

for all Pairwise $\underline{\text { Rookery }} \underline{\text { Comparisons }}$ Based on $\underline{\text { mtDNA Data }}$

\begin{tabular}{|c|c|c|c|c|c|c|c|c|c|c|c|c|c|}
\hline & ADU & AGA & AKN & AKT & AMA & AMC & $\begin{array}{l}\text { ANT } \\
\end{array}$ & ATK & ATT & BOG & BUL & CAP & CHE \\
\hline ADU & & 0.016 & 0.016 & 0.009 & 0.006 & 0.000 & 0.024 & 0.014 & 0.000 & 0.066 & 0.003 & 0.362 & 0.157 \\
\hline AGA & 0.054 & & 0.048 & 0.027 & 0.000 & 0.000 & 0.030 & 0.020 & 0.000 & 0.033 & 0.024 & 0.236 & 0.150 \\
\hline AKN & 0.056 & 0.041 & & 0.000 & 0.000 & 0.000 & 0.028 & 0.003 & 0.000 & 0.026 & 0.009 & 0.197 & 0.125 \\
\hline AKT & 0.062 & 0.000 & 0.004 & & 0.000 & 0.000 & 0.033 & 0.000 & 0.000 & 0.021 & 0.002 & 0.212 & 0.074 \\
\hline AMA & 0.017 & 0.000 & 0.000 & 0.000 & & 0.000 & 0.025 & 0.000 & 0.000 & 0.000 & 0.026 & 0.056 & 0.147 \\
\hline AMC & 0.000 & 0.000 & 0.000 & 0.000 & 0.000 & & 0.013 & 0.000 & 0.000 & 0.000 & 0.015 & 0.102 & 0.150 \\
\hline ANT & 0.157 & 0.057 & 0.022 & 0.043 & 0.029 & 0.057 & & 0.027 & 0.000 & 0.062 & 0.027 & 0.311 & 0.147 \\
\hline ATK & 0.103 & 0.015 & 0.000 & 0.000 & 0.004 & 0.010 & 0.020 & & 0.000 & 0.042 & 0.000 & 0.262 & 0.088 \\
\hline ATT & 0.000 & 0.009 & 0.022 & 0.015 & 0.000 & 0.000 & 0.102 & 0.037 & & 0.012 & 0.000 & 0.196 & 0.115 \\
\hline BOG & 0.079 & 0.053 & 0.052 & 0.055 & 0.000 & 0.000 & 0.111 & 0.076 & 0.002 & & 0.066 & 0.117 & 0.026 \\
\hline BUL & 0.103 & 0.011 & 0.013 & 0.000 & 0.039 & 0.032 & 0.042 & 0.000 & 0.047 & 0.117 & & 0.370 & 0.086 \\
\hline CAP & 0.066 & 0.142 & 0.089 & 0.117 & 0.000 & 0.018 & 0.212 & 0.171 & 0.000 & 0.000 & 0.266 & & 0.848 \\
\hline CHE & 0.346 & 0.180 & 0.110 & 0.085 & 0.279 & 0.289 & 0.142 & 0.085 & 0.296 & 0.154 & 0.087 & 0.788 & \\
\hline CHB & 0.350 & 0.146 & 0.119 & 0.108 & 0.192 & 0.215 & 0.019 & 0.076 & 0.282 & 0.252 & 0.092 & 0.530 & 0.160 \\
\hline CHF & 0.084 & 0.014 & 0.000 & 0.000 & 0.000 & 0.000 & 0.028 & 0.000 & 0.018 & 0.038 & 0.000 & 0.101 & 0.085 \\
\hline CHW & 0.103 & 0.029 & 0.000 & 0.001 & 0.000 & 0.003 & 0.045 & 0.012 & 0.042 & 0.000 & 0.049 & 0.101 & 0.000 \\
\hline CHO & 0.038 & 0.073 & 0.070 & 0.061 & 0.000 & 0.000 & 0.176 & 0.098 & 0.000 & 0.006 & 0.137 & 0.000 & 0.479 \\
\hline CLU & 0.073 & 0.003 & 0.006 & 0.000 & 0.000 & 0.000 & 0.051 & 0.000 & 0.000 & 0.031 & 0.016 & 0.109 & 0.231 \\
\hline FIS & 0.106 & 0.000 & 0.053 & 0.005 & 0.026 & 0.019 & 0.074 & 0.025 & 0.050 & 0.076 & 0.016 & 0.173 & 0.137 \\
\hline FOR & 0.420 & 0.292 & 0.228 & 0.265 & 0.314 & 0.333 & 0.204 & 0.234 & 0.375 & 0.316 & 0.226 & 0.495 & 0.188 \\
\hline GRA & 0.071 & 0.000 & 0.019 & 0.000 & 0.000 & 0.000 & 0.000 & 0.000 & 0.000 & 0.028 & 0.000 & 0.220 & 0.191 \\
\hline HAZ & 0.461 & 0.286 & 0.250 & 0.258 & 0.339 & 0.343 & 0.193 & 0.222 & 0.407 & 0.372 & 0.216 & 0.576 & 0.205 \\
\hline ION & 0.314 & 0.125 & 0.189 & 0.108 & 0.159 & 0.176 & 0.034 & 0.088 & 0.228 & 0.277 & 0.102 & 0.535 & 0.312 \\
\hline KAS & 0.029 & 0.000 & 0.074 & 0.017 & 0.000 & 0.000 & 0.127 & 0.044 & 0.000 & 0.035 & 0.051 & 0.119 & 0.425 \\
\hline CSS & 0.045 & 0.000 & 0.012 & 0.000 & 0.000 & 0.000 & 0.049 & 0.000 & 0.006 & 0.077 & 0.000 & 0.152 & 0.134 \\
\hline LIE & 0.065 & 0.000 & 0.064 & 0.012 & 0.000 & 0.000 & 0.077 & 0.028 & 0.017 & 0.072 & 0.019 & 0.151 & 0.221 \\
\hline KOZ & 0.132 & 0.004 & 0.082 & 0.019 & 0.048 & 0.039 & 0.041 & 0.014 & 0.063 & 0.138 & 0.006 & 0.295 & 0.195 \\
\hline LAT & 0.179 & 0.000 & 0.000 & 0.000 & 0.137 & 0.162 & 0.000 & 0.000 & 0.155 & 0.000 & 0.000 & $\infty$ & 0.000 \\
\hline LOV & 0.291 & 0.100 & 0.106 & 0.083 & 0.131 & 0.157 & 0.014 & 0.057 & 0.222 & 0.190 & 0.068 & 0.425 & 0.162 \\
\hline MAR & 0.069 & 0.000 & 0.032 & 0.006 & 0.000 & 0.000 & 0.070 & 0.024 & 0.000 & 0.025 & 0.044 & 0.062 & 0.232 \\
\hline MED & 0.013 & 0.000 & 0.029 & 0.008 & 0.000 & 0.000 & 0.062 & 0.024 & 0.000 & 0.045 & 0.019 & 0.068 & 0.165 \\
\hline NOR & 0.867 & 0.620 & 0.544 & 0.530 & 0.746 & 0.804 & 0.434 & 0.517 & 0.827 & 0.667 & 0.517 & 1.265 & 0.498 \\
\hline OGC & 0.128 & 0.037 & 0.052 & 0.021 & 0.012 & 0.051 & 0.020 & 0.019 & 0.075 & 0.029 & 0.025 & 0.141 & 0.032 \\
\hline PIN & 0.074 & 0.016 & 0.000 & 0.000 & 0.000 & 0.000 & 0.039 & 0.000 & 0.010 & 0.003 & 0.022 & 0.041 & 0.081 \\
\hline RAY & 0.273 & 0.092 & 0.091 & 0.067 & 0.118 & 0.132 & 0.012 & 0.044 & 0.199 & 0.190 & 0.061 & 0.424 & 0.184 \\
\hline ROG & 0.428 & 0.277 & 0.254 & 0.261 & 0.315 & 0.318 & 0.205 & 0.226 & 0.377 & 0.360 & 0.218 & 0.514 & 0.217 \\
\hline SEA & 0.092 & 0.011 & 0.000 & 0.006 & 0.000 & 0.000 & 0.043 & 0.009 & 0.042 & 0.037 & 0.022 & 0.080 & 0.083 \\
\hline SEG & 0.000 & 0.000 & 0.008 & 0.000 & 0.000 & 0.000 & 0.073 & 0.019 & 0.000 & 0.038 & 0.014 & 0.047 & 0.178 \\
\hline SRE & 0.343 & 0.135 & 0.178 & 0.109 & 0.194 & 0.207 & 0.035 & 0.087 & 0.264 & 0.274 & 0.097 & 0.589 & 0.251 \\
\hline SGR & 0.596 & 0.382 & 0.325 & 0.322 & 0.499 & 0.510 & 0.266 & 0.303 & 0.548 & 0.461 & 0.300 & 0.914 & 0.288 \\
\hline SUG & 0.064 & 0.000 & 0.023 & 0.000 & 0.000 & 0.000 & 0.060 & 0.009 & 0.013 & 0.057 & 0.000 & 0.116 & 0.151 \\
\hline TRI & 0.571 & 0.410 & 0.348 & 0.375 & 0.453 & 0.485 & 0.290 & 0.343 & 0.527 & 0.450 & 0.328 & 0.709 & 0.282 \\
\hline UGA & 0.074 & 0.009 & 0.009 & 0.000 & 0.000 & 0.000 & 0.046 & 0.000 & 0.013 & 0.025 & 0.009 & 0.071 & 0.087 \\
\hline ULA & 0.165 & 0.076 & 0.087 & 0.085 & 0.057 & 0.087 & 0.043 & 0.065 & 0.116 & 0.079 & 0.068 & 0.167 & 0.117 \\
\hline WAL & 0.057 & 0.000 & 0.000 & 0.000 & 0.000 & 0.000 & 0.058 & 0.000 & 0.001 & 0.063 & 0.000 & 0.143 & 0.090 \\
\hline WHA & 0.000 & 0.000 & 0.000 & 0.000 & 0.000 & 0.000 & 0.000 & 0.000 & 0.000 & 0.000 & 0.000 & 0.333 & 0.101 \\
\hline WHI & 0.339 & 0.262 & 0.181 & 0.264 & 0.243 & 0.259 & 0.201 & 0.210 & 0.296 & 0.267 & 0.185 & 0.328 & 0.121 \\
\hline YAM & 0.290 & 0.117 & 0.171 & 0.101 & 0.147 & 0.167 & 0.026 & 0.082 & 0.213 & 0.246 & 0.096 & 0.500 & 0.286 \\
\hline YUN & 0.028 & 0.014 & 0.025 & 0.036 & 0.000 & 0.000 & 0.111 & 0.063 & 0.000 & 0.002 & 0.087 & 0.000 & 0.267 \\
\hline ZHE & 0.251 & 0.060 & 0.096 & 0.037 & 0.132 & 0.134 & 0.004 & 0.021 & 0.157 & 0.125 & 0.034 & 0.638 & 0.141 \\
\hline
\end{tabular}

Note- Rookery designations are as follows: $\mathrm{ADU}=$ Adugak Island, $\mathrm{AGA}=$ Agattu Island, $\mathrm{AKN}=$ Akun Island, $\mathrm{AKT}=\mathrm{Akutan}$ Island, $\mathrm{AMA}=\mathrm{Amak}$ Island, $\mathrm{AMC}=$ Amchitka Island, ANT $=$ Antsiferova Island, ATK $=$ Atkins Island, ATT $=$ Attu Island, $\mathrm{BOG}=$ Bogoslof Island, $\mathrm{BUL}=$ Buldir Island, $\mathrm{CAP}=\mathrm{Cape}$ St. Elias, $\mathrm{CHE}=$ Chernabura Island, $\mathrm{CHB}=$ Chernyye Brat'ya, $\mathrm{CHF}=\mathrm{Chirikof}$ Island, $\mathrm{CHW}=$ Chiswell Island, $\mathrm{CHO}=$ Chowiet Island, $\mathrm{CLU}=$ Clubbing Rocks, FIS $=$ Fish Island, FOR $=$ Forrester Island, designations continued on following page. 
Appendix II Continued

\begin{tabular}{|c|c|c|c|c|c|c|c|c|c|c|c|c|c|}
\hline & CHB & CHF & CHW & СHO & CLU & FIS & FOR & $\begin{array}{l}\text { GRA } \\
\end{array}$ & $\overline{\text { HAZ }}$ & ION & KAS & CSS & LIE \\
\hline ADU & 0.090 & 0.028 & 0.038 & 0.112 & 0.017 & 0.026 & 0.042 & 0.000 & 0.075 & 0.114 & 0.067 & 0.003 & 0.022 \\
\hline AGA & 0.074 & 0.052 & 0.011 & 0.106 & 0.009 & 0.018 & 0.035 & 0.000 & 0.070 & 0.117 & 0.026 & 0.010 & 0.000 \\
\hline AKN & 0.131 & 0.000 & 0.026 & 0.019 & 0.002 & 0.011 & 0.050 & 0.000 & 0.118 & 0.184 & 0.031 & 0.019 & 0.048 \\
\hline AKT & 0.087 & 0.001 & 0.005 & 0.045 & 0.000 & 0.000 & 0.040 & 0.000 & 0.081 & 0.132 & 0.042 & 0.004 & 0.037 \\
\hline AMA & 0.135 & 0.000 & 0.000 & 0.000 & 0.000 & 0.001 & 0.044 & 0.000 & 0.120 & 0.181 & 0.000 & 0.004 & 0.003 \\
\hline AMC & 0.076 & 0.000 & 0.000 & 0.000 & 0.000 & 0.000 & 0.025 & 0.000 & 0.069 & 0.114 & 0.000 & 0.000 & 0.001 \\
\hline ANT & 0.026 & 0.049 & 0.025 & 0.143 & 0.039 & 0.034 & 0.015 & 0.004 & 0.027 & 0.037 & 0.124 & 0.049 & 0.065 \\
\hline ATK & 0.059 & 0.008 & 0.020 & 0.081 & 0.000 & 0.012 & 0.026 & 0.000 & 0.059 & 0.124 & 0.049 & 0.000 & 0.033 \\
\hline ATT & 0.077 & 0.000 & 0.000 & 0.004 & 0.000 & 0.000 & 0.020 & 0.000 & 0.063 & 0.099 & 0.000 & 0.000 & 0.000 \\
\hline BOG & 0.146 & 0.007 & 0.000 & 0.017 & 0.015 & 0.012 & 0.043 & 0.000 & 0.133 & 0.219 & 0.046 & 0.041 & 0.068 \\
\hline BUL & 0.074 & 0.023 & 0.043 & 0.124 & 0.020 & 0.020 & 0.032 & 0.000 & 0.069 & 0.129 & 0.056 & 0.000 & 0.014 \\
\hline CAP & 0.523 & 0.165 & 0.244 & 0.000 & 0.145 & 0.222 & 0.354 & 0.172 & 0.492 & 0.616 & 0.120 & 0.245 & 0.260 \\
\hline CHE & 0.233 & 0.064 & 0.000 & 0.258 & 0.124 & 0.097 & 0.138 & 0.122 & 0.216 & 0.320 & 0.240 & 0.100 & 0.175 \\
\hline CHB & & 0.150 & 0.099 & 0.284 & 0.086 & 0.088 & 0.035 & 0.058 & 0.012 & 0.042 & 0.256 & 0.085 & 0.137 \\
\hline CHF & 0.116 & & 0.000 & 0.014 & 0.003 & 0.015 & 0.069 & 0.000 & 0.137 & 0.201 & 0.020 & 0.020 & 0.049 \\
\hline CHW & 0.143 & 0.000 & & 0.072 & 0.000 & 0.007 & 0.027 & 0.000 & 0.084 & 0.135 & 0.082 & 0.038 & 0.071 \\
\hline CHO & 0.410 & 0.053 & 0.089 & & 0.023 & 0.053 & 0.159 & 0.029 & 0.266 & 0.357 & 0.000 & 0.071 & 0.099 \\
\hline CLU & 0.171 & 0.000 & 0.007 & 0.025 & & 0.009 & 0.044 & 0.000 & 0.084 & 0.140 & 0.011 & 0.000 & 0.031 \\
\hline FIS & 0.135 & 0.021 & 0.041 & 0.092 & 0.025 & & 0.039 & 0.000 & 0.080 & 0.132 & 0.056 & 0.017 & 0.041 \\
\hline FOR & 0.155 & 0.272 & 0.205 & 0.508 & 0.359 & 0.269 & & 0.008 & 0.000 & 0.098 & 0.140 & 0.040 & 0.076 \\
\hline GRA & 0.078 & 0.000 & 0.022 & 0.079 & 0.000 & 0.000 & 0.213 & & 0.060 & 0.117 & 0.000 & 0.000 & 0.000 \\
\hline HAZ & 0.117 & 0.271 & 0.243 & 0.522 & 0.326 & 0.260 & 0.000 & 0.216 & & 0.037 & 0.239 & 0.088 & 0.133 \\
\hline ION & 0.062 & 0.135 & 0.201 & 0.369 & 0.140 & 0.140 & 0.322 & 0.037 & 0.258 & & 0.330 & 0.164 & 0.193 \\
\hline KAS & 0.326 & 0.022 & 0.104 & 0.000 & 0.000 & 0.022 & 0.446 & 0.000 & 0.444 & 0.254 & & 0.021 & 0.000 \\
\hline CSS & 0.126 & 0.000 & 0.035 & 0.073 & 0.000 & 0.013 & 0.285 & 0.000 & 0.275 & 0.110 & 0.009 & & 0.008 \\
\hline LIE & 0.173 & 0.028 & 0.066 & 0.076 & 0.016 & 0.006 & 0.341 & 0.000 & 0.329 & 0.138 & 0.000 & 0.000 & \\
\hline KOZ & 0.097 & 0.036 & 0.090 & 0.163 & 0.035 & 0.023 & 0.309 & 0.000 & 0.270 & 0.054 & 0.052 & 0.013 & 0.018 \\
\hline LAT & 0.000 & 0.000 & 0.000 & 0.555 & 0.068 & 0.000 & 0.000 & 0.000 & 0.000 & 0.000 & 0.457 & 0.000 & 0.000 \\
\hline LOV & 0.000 & 0.092 & 0.109 & 0.330 & 0.119 & 0.109 & 0.176 & 0.018 & 0.146 & 0.039 & 0.246 & 0.086 & 0.118 \\
\hline MAR & 0.195 & 0.002 & 0.014 & 0.017 & 0.000 & 0.013 & 0.398 & 0.000 & 0.375 & 0.163 & 0.000 & 0.013 & 0.008 \\
\hline MED & 0.146 & 0.019 & 0.030 & 0.043 & 0.005 & 0.018 & 0.304 & 0.000 & 0.308 & 0.122 & 0.000 & 0.000 & 0.000 \\
\hline NOR & 0.382 & 0.575 & 0.580 & 1.084 & 0.788 & 0.538 & 0.011 & 0.548 & 0.057 & 0.607 & 0.993 & 0.569 & 0.653 \\
\hline OGC & 0.057 & 0.029 & 0.000 & 0.132 & 0.047 & 0.049 & 0.155 & 0.000 & 0.185 & 0.070 & 0.096 & 0.026 & 0.049 \\
\hline PIN & 0.129 & 0.000 & 0.000 & 0.038 & 0.000 & 0.033 & 0.275 & 0.000 & 0.278 & 0.158 & 0.028 & 0.011 & 0.037 \\
\hline RAY & 0.011 & 0.080 & 0.093 & 0.311 & 0.092 & 0.103 & 0.211 & 0.013 & 0.171 & 0.031 & 0.237 & 0.070 & 0.112 \\
\hline ROG & 0.139 & 0.268 & 0.245 & 0.466 & 0.298 & 0.256 & 0.000 & 0.207 & 0.000 & 0.251 & 0.399 & 0.269 & 0.313 \\
\hline SEA & 0.110 & 0.000 & 0.000 & 0.071 & 0.003 & 0.025 & 0.261 & 0.000 & 0.261 & 0.149 & 0.042 & 0.015 & 0.031 \\
\hline SEG & 0.185 & 0.009 & 0.024 & 0.018 & 0.000 & 0.019 & 0.318 & 0.000 & 0.330 & 0.168 & 0.000 & 0.000 & 0.000 \\
\hline SRE & 0.011 & 0.139 & 0.186 & 0.416 & 0.159 & 0.141 & 0.236 & 0.048 & 0.181 & 0.018 & 0.307 & 0.111 & 0.151 \\
\hline SGR & 0.211 & 0.352 & 0.342 & 0.761 & 0.495 & 0.324 & 0.000 & 0.344 & 0.000 & 0.394 & 0.667 & 0.356 & 0.426 \\
\hline SUG & 0.143 & 0.002 & 0.041 & 0.055 & 0.008 & 0.000 & 0.258 & 0.000 & 0.272 & 0.150 & 0.000 & 0.000 & 0.000 \\
\hline TRI & 0.226 & 0.390 & 0.333 & 0.689 & 0.506 & 0.378 & 0.000 & 0.312 & 0.000 & 0.408 & 0.609 & 0.393 & 0.458 \\
\hline UGA & 0.120 & 0.000 & 0.000 & 0.045 & 0.000 & 0.026 & 0.286 & 0.000 & 0.284 & 0.115 & 0.015 & 0.001 & 0.021 \\
\hline ULA & 0.065 & 0.090 & 0.047 & 0.198 & 0.110 & 0.095 & 0.018 & 0.000 & 0.057 & 0.091 & 0.141 & 0.082 & 0.093 \\
\hline WAL & 0.141 & 0.000 & 0.016 & 0.054 & 0.000 & 0.009 & 0.265 & 0.000 & 0.270 & 0.142 & 0.003 & 0.000 & 0.010 \\
\hline WHA & 0.166 & 0.000 & 0.000 & 0.000 & 0.000 & 0.000 & 0.166 & 0.000 & 0.252 & 0.135 & 0.000 & 0.000 & 0.000 \\
\hline WHI & 0.144 & 0.239 & 0.148 & 0.378 & 0.291 & 0.260 & 0.000 & 0.168 & 0.000 & 0.327 & 0.332 & 0.263 & 0.319 \\
\hline YAM & 0.043 & 0.127 & 0.182 & 0.349 & 0.137 & 0.132 & 0.282 & 0.029 & 0.229 & 0.000 & 0.243 & 0.102 & 0.129 \\
\hline YUN & 0.255 & 0.034 & 0.012 & 0.003 & 0.010 & 0.057 & 0.391 & 0.011 & 0.399 & 0.260 & 0.000 & 0.038 & 0.027 \\
\hline ZHE & 0.014 & 0.058 & 0.074 & 0.351 & 0.085 & 0.064 & 0.176 & 0.005 & 0.143 & 0.006 & 0.250 & 0.045 & 0.083 \\
\hline
\end{tabular}

Note- Region designations continued: GRA = Gramp Rocks, HAZ = Hazy Islands, ION = Iony Island, KAS = Kasatoshi Island, CSS $=$ Kiska Island, Cape St. Stephen, LIE $=$ Kiska Island, Lief Cove, $\mathrm{KOZ}=$ Kozlova Cape, LAT $=$ Latax Rocks, LOV $=$ Lovushki Island, MAR $=$ Marmot Island, MED $=$ Medney Island, $\mathrm{NOR}=$ North Danger Rocks, OGC $=$ Ogchul Island, PIN $=$ Pinnacle Rocks, RAY $=$ Raykoke Island, $\mathrm{ROG}=$ Rogue Reef, $\mathrm{SEA}=$ Seal Rocks, $\mathrm{SEG}=$ Seguam Island, $\mathrm{SRE}=$ Srednego Island, $\mathrm{SGR}=\mathrm{St} . \mathrm{George}$ Reef, $\mathrm{SUG}=$ Sugarloaf Island, TRI $=$ Triangle Island, UGA = Ugamak Island, ULA = Ulak Island, WAL $=$ Walrus Island, WHA = Whaleback Island, $\mathrm{WHI}=$ White Sisters Islands, YAM = Yamsky Island, YUN = Yunaska Island, and ZHE = Zheleznaya Bay. 
Appendix II Continued

\begin{tabular}{|c|c|c|c|c|c|c|c|c|c|c|c|c|c|}
\hline & $\mathrm{KOZ}$ & LAT & LOV & MAR & MED & NOR & OGC & PIN & RAY & ROG & SEA & SEG & SRE \\
\hline ADU & 0.023 & 0.154 & 0.071 & 0.038 & 0.000 & 0.176 & 0.067 & 0.024 & 0.067 & 0.085 & 0.031 & 0.000 & 0.086 \\
\hline AGA & 0.031 & 0.053 & 0.049 & 0.013 & 0.000 & 0.170 & 0.048 & 0.020 & 0.049 & 0.087 & 0.010 & 0.000 & 0.079 \\
\hline AKN & 0.077 & 0.164 & 0.105 & 0.002 & 0.030 & 0.194 & 0.049 & 0.000 & 0.094 & 0.112 & 0.000 & 0.000 & 0.132 \\
\hline AKT & 0.047 & 0.057 & 0.073 & 0.014 & 0.018 & 0.167 & 0.036 & 0.000 & 0.061 & 0.093 & 0.004 & 0.000 & 0.092 \\
\hline AMA & 0.066 & 0.200 & 0.098 & 0.000 & 0.001 & 0.211 & 0.031 & 0.000 & 0.083 & 0.118 & 0.000 & 0.000 & 0.131 \\
\hline AMC & 0.027 & 0.066 & 0.054 & 0.000 & 0.000 & 0.192 & 0.035 & 0.000 & 0.038 & 0.092 & 0.000 & 0.000 & 0.081 \\
\hline ANT & 0.013 & 0.052 & 0.019 & 0.056 & 0.033 & 0.119 & 0.036 & 0.038 & 0.020 & 0.043 & 0.036 & 0.028 & 0.017 \\
\hline ATK & 0.036 & 0.000 & 0.053 & 0.026 & 0.012 & 0.161 & 0.038 & 0.000 & 0.037 & 0.083 & 0.006 & 0.000 & 0.073 \\
\hline ATT & 0.004 & 0.125 & 0.053 & 0.000 & 0.000 & 0.161 & 0.032 & 0.000 & 0.046 & 0.073 & 0.000 & 0.000 & 0.074 \\
\hline BOG & 0.125 & 0.146 & 0.114 & 0.000 & 0.035 & 0.195 & 0.000 & 0.000 & 0.103 & 0.119 & 0.000 & 0.017 & 0.148 \\
\hline BUL & 0.019 & 0.037 & 0.063 & 0.049 & 0.009 & 0.147 & 0.044 & 0.022 & 0.060 & 0.076 & 0.022 & 0.000 & 0.081 \\
\hline CAP & 0.434 & $\infty$ & 0.432 & 0.089 & 0.232 & 0.761 & 0.281 & 0.129 & 0.401 & 0.448 & 0.142 & 0.190 & 0.520 \\
\hline CHE & 0.195 & 0.429 & 0.206 & 0.128 & 0.126 & 0.318 & 0.013 & 0.039 & 0.199 & 0.195 & 0.073 & 0.098 & 0.236 \\
\hline CHB & 0.035 & 0.000 & 0.000 & 0.151 & 0.080 & 0.158 & 0.104 & 0.107 & 0.000 & 0.061 & 0.098 & 0.096 & 0.000 \\
\hline $\mathrm{CHF}$ & 0.089 & 0.195 & 0.122 & 0.000 & 0.036 & 0.210 & 0.040 & 0.000 & 0.109 & 0.130 & 0.002 & 0.003 & 0.150 \\
\hline CHW & 0.069 & 0.154 & 0.074 & 0.000 & 0.029 & 0.185 & 0.000 & 0.000 & 0.064 & 0.089 & 0.000 & 0.008 & 0.097 \\
\hline CHO & 0.207 & 0.552 & 0.230 & 0.004 & 0.087 & 0.385 & 0.115 & 0.017 & 0.209 & 0.240 & 0.033 & 0.040 & 0.285 \\
\hline CLU & 0.051 & 0.019 & 0.071 & 0.000 & 0.014 & 0.205 & 0.052 & 0.000 & 0.049 & 0.110 & 0.000 & 0.000 & 0.097 \\
\hline FIS & 0.053 & 0.066 & 0.073 & 0.013 & 0.018 & 0.163 & 0.042 & 0.007 & 0.063 & 0.092 & 0.005 & 0.002 & 0.093 \\
\hline FOR & 0.048 & 0.000 & 0.032 & 0.077 & 0.033 & 0.040 & 0.025 & 0.042 & 0.027 & 0.000 & 0.038 & 0.034 & 0.044 \\
\hline GRA & 0.017 & 0.000 & 0.019 & 0.000 & 0.000 & 0.157 & 0.000 & 0.000 & 0.019 & 0.070 & 0.000 & 0.000 & 0.056 \\
\hline HAZ & 0.032 & 0.000 & 0.025 & 0.139 & 0.076 & 0.093 & 0.094 & 0.099 & 0.016 & 0.016 & 0.095 & 0.087 & 0.017 \\
\hline ION & 0.034 & 0.177 & 0.050 & 0.188 & 0.128 & 0.212 & 0.160 & 0.160 & 0.045 & 0.086 & 0.155 & 0.142 & 0.021 \\
\hline KAS & 0.141 & 0.452 & 0.201 & 0.000 & 0.029 & 0.343 & 0.110 & 0.020 & 0.192 & 0.216 & 0.022 & 0.004 & 0.258 \\
\hline CSS & 0.056 & 0.000 & 0.066 & 0.028 & 0.000 & 0.175 & 0.042 & 0.010 & 0.056 & 0.101 & 0.011 & 0.000 & 0.099 \\
\hline LIE & 0.061 & 0.168 & 0.097 & 0.029 & 0.002 & 0.208 & 0.077 & 0.042 & 0.103 & 0.128 & 0.031 & 0.000 & 0.139 \\
\hline $\mathrm{KOZ}$ & & 0.100 & 0.033 & 0.085 & 0.040 & 0.157 & 0.101 & 0.070 & 0.032 & 0.064 & 0.068 & 0.042 & 0.027 \\
\hline LAT & 0.000 & & 0.000 & 0.218 & 0.037 & 0.250 & 0.071 & 0.086 & 0.000 & 0.060 & 0.053 & 0.087 & 0.000 \\
\hline LOV & 0.078 & 0.000 & & 0.118 & 0.058 & 0.149 & 0.079 & 0.085 & 0.000 & 0.058 & 0.078 & 0.073 & 0.004 \\
\hline MAR & 0.042 & 0.046 & 0.148 & & 0.024 & 0.231 & 0.053 & 0.000 & 0.107 & 0.140 & 0.000 & 0.001 & 0.151 \\
\hline MED & 0.027 & 0.000 & 0.104 & 0.007 & & 0.152 & 0.037 & 0.020 & 0.057 & 0.084 & 0.015 & 0.000 & 0.083 \\
\hline NOR & 0.629 & 0.000 & 0.380 & 0.782 & 0.558 & & 0.154 & 0.187 & 0.152 & 0.053 & 0.174 & 0.163 & 0.157 \\
\hline OGC & 0.056 & 0.000 & 0.014 & 0.064 & 0.032 & 0.358 & & 0.014 & 0.080 & 0.077 & 0.023 & 0.028 & 0.089 \\
\hline PIN & 0.057 & 0.000 & 0.100 & 0.000 & 0.019 & 0.593 & 0.022 & & 0.072 & 0.107 & 0.000 & 0.000 & 0.113 \\
\hline RAY & 0.067 & 0.000 & 0.000 & 0.127 & 0.090 & 0.462 & 0.021 & 0.083 & & 0.060 & 0.068 & 0.067 & 0.004 \\
\hline ROG & 0.264 & 0.000 & 0.160 & 0.347 & 0.309 & 0.035 & 0.188 & 0.276 & 0.177 & & 0.103 & 0.090 & 0.056 \\
\hline SEA & 0.059 & 0.000 & 0.082 & 0.012 & 0.023 & 0.527 & 0.035 & 0.000 & 0.070 & 0.269 & & 0.000 & 0.108 \\
\hline SEG & 0.039 & 0.000 & 0.136 & 0.000 & 0.000 & 0.625 & 0.042 & 0.008 & 0.119 & 0.319 & 0.015 & & 0.096 \\
\hline SRE & 0.074 & 0.000 & 0.003 & 0.188 & 0.129 & 0.490 & 0.051 & 0.155 & 0.005 & 0.185 & 0.136 & 0.173 & \\
\hline SGR & 0.378 & 0.000 & 0.238 & 0.504 & 0.369 & 0.001 & 0.259 & 0.368 & 0.280 & 0.000 & 0.322 & 0.409 & 0.307 \\
\hline SUG & 0.015 & 0.000 & 0.106 & 0.000 & 0.000 & 0.543 & 0.031 & 0.019 & 0.107 & 0.272 & 0.009 & 0.000 & 0.151 \\
\hline TRI & 0.425 & 0.000 & 0.238 & 0.547 & 0.412 & 0.000 & 0.225 & 0.403 & 0.291 & 0.000 & 0.378 & 0.438 & 0.298 \\
\hline UGA & 0.037 & 0.000 & 0.083 & 0.004 & 0.014 & 0.553 & 0.003 & 0.000 & 0.066 & 0.285 & 0.005 & 0.006 & 0.114 \\
\hline ULA & 0.090 & 0.000 & 0.030 & 0.134 & 0.084 & 0.192 & 0.000 & 0.089 & 0.047 & 0.069 & 0.094 & 0.095 & 0.067 \\
\hline WAL & 0.019 & 0.000 & 0.109 & 0.011 & 0.005 & 0.572 & 0.021 & 0.000 & 0.093 & 0.262 & 0.011 & 0.000 & 0.140 \\
\hline WHA & 0.000 & 0.005 & 0.111 & 0.000 & 0.000 & 0.673 & 0.000 & 0.000 & 0.094 & 0.222 & 0.000 & 0.000 & 0.170 \\
\hline WHI & 0.298 & 0.000 & 0.164 & 0.365 & 0.313 & 0.000 & 0.136 & 0.243 & 0.194 & 0.000 & 0.258 & 0.289 & 0.212 \\
\hline YAM & 0.055 & 0.000 & 0.028 & 0.158 & 0.112 & 0.554 & 0.045 & 0.145 & 0.024 & 0.224 & 0.139 & 0.152 & 0.005 \\
\hline YUN & 0.107 & 0.057 & 0.193 & 0.005 & 0.013 & 0.773 & 0.088 & 0.008 & 0.177 & 0.374 & 0.017 & 0.000 & 0.265 \\
\hline ZHE & 0.022 & 0.000 & 0.000 & 0.105 & 0.060 & 0.491 & 0.002 & 0.059 & 0.000 & 0.149 & 0.057 & 0.091 & 0.000 \\
\hline
\end{tabular}


Appendix II Continued

\begin{tabular}{|c|c|c|c|c|c|c|c|c|c|c|c|}
\hline & SGR & SUG & TRI & UGA & ULA & WAL & WHA & WHI & YAM & YUN & ZHE \\
\hline ADU & 0.131 & 0.023 & 0.059 & 0.025 & 0.051 & 0.013 & 0.000 & 0.056 & 0.083 & 0.066 & 0.089 \\
\hline AGA & 0.121 & 0.000 & 0.059 & 0.024 & 0.035 & 0.037 & 0.000 & 0.051 & 0.085 & 0.021 & 0.071 \\
\hline AKN & 0.150 & 0.007 & 0.086 & 0.000 & 0.116 & 0.000 & 0.000 & 0.049 & 0.129 & 0.032 & 0.141 \\
\hline AKT & 0.123 & 0.001 & 0.066 & 0.000 & 0.072 & 0.000 & 0.000 & 0.041 & 0.096 & 0.049 & 0.082 \\
\hline AMA & 0.163 & 0.000 & 0.091 & 0.000 & 0.104 & 0.000 & 0.000 & 0.052 & 0.131 & 0.000 & 0.134 \\
\hline AMC & 0.134 & 0.000 & 0.063 & 0.000 & 0.052 & 0.000 & 0.000 & 0.036 & 0.088 & 0.000 & 0.073 \\
\hline ANT & 0.082 & 0.049 & 0.021 & 0.043 & 0.011 & 0.051 & 0.000 & 0.040 & 0.010 & 0.104 & 0.026 \\
\hline ATK & 0.105 & 0.000 & 0.050 & 0.009 & 0.044 & 0.000 & 0.000 & 0.022 & 0.087 & 0.064 & 0.052 \\
\hline ATT & 0.116 & 0.000 & 0.046 & 0.000 & 0.038 & 0.000 & 0.000 & 0.034 & 0.071 & 0.006 & 0.075 \\
\hline BOG & 0.150 & 0.020 & 0.089 & 0.000 & 0.136 & 0.013 & 0.000 & 0.047 & 0.147 & 0.020 & 0.136 \\
\hline BUL & 0.103 & 0.000 & 0.046 & 0.022 & 0.045 & 0.000 & 0.000 & 0.032 & 0.079 & 0.081 & 0.075 \\
\hline CAP & 0.644 & 0.217 & 0.470 & 0.141 & 0.628 & 0.208 & 0.333 & 0.316 & 0.509 & 0.058 & 0.643 \\
\hline CHE & 0.255 & 0.125 & 0.170 & 0.058 & 0.238 & 0.048 & 0.005 & 0.128 & 0.231 & 0.192 & 0.206 \\
\hline CHB & 0.094 & 0.104 & 0.031 & 0.111 & 0.010 & 0.121 & 0.107 & 0.054 & 0.020 & 0.217 & 0.000 \\
\hline CHF & 0.170 & 0.016 & 0.108 & 0.000 & 0.135 & 0.000 & 0.000 & 0.065 & 0.148 & 0.034 & 0.149 \\
\hline CHW & 0.135 & 0.039 & 0.060 & 0.000 & 0.075 & 0.006 & 0.000 & 0.049 & 0.094 & 0.034 & 0.070 \\
\hline СНО & 0.324 & 0.049 & 0.234 & 0.022 & 0.309 & 0.020 & 0.000 & 0.137 & 0.279 & 0.007 & 0.333 \\
\hline CLU & 0.145 & 0.001 & 0.081 & 0.000 & 0.077 & 0.000 & 0.000 & 0.043 & 0.110 & 0.020 & 0.077 \\
\hline FIS & 0.123 & 0.000 & 0.065 & 0.007 & 0.069 & 0.002 & 0.000 & 0.046 & 0.096 & 0.054 & 0.083 \\
\hline FOR & 0.000 & 0.033 & 0.000 & 0.046 & 0.025 & 0.051 & 0.000 & 0.000 & 0.051 & 0.117 & 0.035 \\
\hline GRA & 0.103 & 0.000 & 0.043 & 0.000 & 0.037 & 0.000 & 0.000 & 0.012 & 0.064 & 0.000 & 0.062 \\
\hline HAZ & 0.026 & 0.100 & 0.000 & 0.104 & 0.000 & 0.116 & 0.091 & 0.029 & 0.030 & 0.205 & 0.000 \\
\hline ION & 0.162 & 0.189 & 0.076 & 0.156 & 0.019 & 0.189 & 0.202 & 0.146 & 0.013 & 0.276 & 0.016 \\
\hline KAS & 0.286 & 0.000 & 0.203 & 0.021 & 0.229 & 0.016 & 0.000 & 0.122 & 0.252 & 0.000 & 0.296 \\
\hline CSS & 0.121 & 0.000 & 0.070 & 0.012 & 0.077 & 0.000 & 0.000 & 0.029 & 0.111 & 0.044 & 0.089 \\
\hline LIE & 0.167 & 0.000 & 0.107 & 0.036 & 0.096 & 0.033 & 0.000 & 0.077 & 0.138 & 0.022 & 0.153 \\
\hline KOZ & 0.114 & 0.064 & 0.043 & 0.070 & 0.000 & 0.071 & 0.011 & 0.077 & 0.030 & 0.139 & 0.026 \\
\hline LAT & 0.038 & 0.005 & 0.000 & 0.104 & 0.000 & 0.103 & 0.000 & 0.000 & 0.076 & 0.330 & 0.000 \\
\hline LOV & 0.094 & 0.082 & 0.033 & 0.086 & 0.017 & 0.103 & 0.065 & 0.052 & 0.024 & 0.172 & 0.012 \\
\hline MAR & 0.188 & 0.010 & 0.121 & 0.001 & 0.124 & 0.010 & 0.000 & 0.083 & 0.150 & 0.000 & 0.151 \\
\hline MED & 0.110 & 0.000 & 0.057 & 0.021 & 0.050 & 0.021 & 0.000 & 0.039 & 0.087 & 0.034 & 0.081 \\
\hline NOR & 0.044 & 0.170 & 0.019 & 0.178 & 0.146 & 0.190 & 0.176 & 0.065 & 0.154 & 0.291 & 0.172 \\
\hline OGC & 0.111 & 0.040 & 0.055 & 0.013 & 0.085 & 0.033 & 0.000 & 0.032 & 0.080 & 0.080 & 0.086 \\
\hline PIN & 0.140 & 0.009 & 0.080 & 0.000 & 0.095 & 0.000 & 0.000 & 0.044 & 0.116 & 0.016 & 0.099 \\
\hline RAY & 0.091 & 0.076 & 0.031 & 0.076 & 0.014 & 0.090 & 0.044 & 0.042 & 0.026 & 0.164 & 0.000 \\
\hline ROG & 0.000 & 0.101 & 0.006 & 0.106 & 0.044 & 0.114 & 0.075 & 0.037 & 0.057 & 0.187 & 0.055 \\
\hline SEA & 0.129 & 0.000 & 0.075 & 0.000 & 0.086 & 0.000 & 0.000 & 0.040 & 0.111 & 0.017 & 0.095 \\
\hline SEG & 0.122 & 0.000 & 0.064 & 0.000 & 0.068 & 0.000 & 0.000 & 0.038 & 0.096 & 0.012 & 0.095 \\
\hline SRE & 0.103 & 0.117 & 0.036 & 0.110 & 0.011 & 0.130 & 0.114 & 0.071 & 0.000 & 0.219 & 0.000 \\
\hline SGR & & 0.119 & 0.017 & 0.138 & 0.089 & 0.144 & 0.109 & 0.024 & 0.109 & 0.246 & 0.098 \\
\hline SUG & 0.340 & & 0.068 & 0.004 & 0.082 & 0.000 & 0.000 & 0.025 & 0.124 & 0.016 & 0.115 \\
\hline TRI & 0.000 & 0.368 & & 0.082 & 0.015 & 0.086 & 0.029 & 0.000 & 0.041 & 0.176 & 0.027 \\
\hline UGA & 0.355 & 0.011 & 0.398 & & 0.096 & 0.000 & 0.000 & 0.048 & 0.112 & 0.023 & 0.103 \\
\hline ULA & 0.090 & 0.070 & 0.076 & 0.080 & & 0.113 & 0.088 & 0.058 & 0.019 & 0.194 & 0.000 \\
\hline WAL & 0.348 & 0.000 & 0.374 & 0.000 & 0.086 & & 0.000 & 0.042 & 0.132 & 0.035 & 0.126 \\
\hline WHA & 0.393 & 0.000 & 0.320 & 0.000 & 0.000 & 0.000 & & 0.000 & 0.109 & 0.000 & 0.128 \\
\hline WHI & 0.000 & 0.232 & 0.000 & 0.286 & 0.046 & 0.224 & 0.073 & & 0.083 & 0.113 & 0.059 \\
\hline YАM & 0.366 & 0.135 & 0.360 & 0.105 & 0.067 & 0.130 & 0.113 & 0.268 & & 0.215 & 0.016 \\
\hline YUN & 0.518 & 0.024 & 0.539 & 0.026 & 0.139 & 0.044 & 0.000 & 0.344 & 0.241 & & 0.242 \\
\hline ZHE & 0.272 & 0.075 & 0.257 & 0.039 & 0.025 & 0.060 & 0.116 & 0.134 & 0.006 & 0.172 & \\
\hline
\end{tabular}


VITA

CONTACT INFORMATION

Alyson Renee Baker

1015 Dahlia Lane

Jeannette, PA 15644

(724)-527-5003

\section{EDUCATION}

M.S., Genetics, Texas A\&M University, College Station, Texas

Graduation Date: December 2003

B.S., Molecular Biology, Grove City College, Grove City, Pennsylvania Graduation Date: May 19, 2001

\section{RESEARCH INTERESTS}

Conservation Genetics

Population Genetics

Systematics

Phylogeography

Molecular Biology

\section{PUBLICATIONS}

Baker, A. R., T. R. Loughlin, C. W. Matson, J. C. Patton and J. W. Bickham. Submitted December 2003. Variation of mitochondrial control region sequences of Steller sea lions: the three-stock hypothesis. Journal of Mammalogy. 